Portland State University

PDXScholar

5-16-1978

\title{
A Biogeographical Study of Currently Identified Oregon Pseudoscorpions With an Emphasis on Western Oregon Forms
}

Ellen M. Benedict

Portland State University

Follow this and additional works at: https://pdxscholar.library.pdx.edu/open_access_etds Let us know how access to this document benefits you.

\section{Recommended Citation}

Benedict, Ellen M., "A Biogeographical Study of Currently Identified Oregon Pseudoscorpions With an Emphasis on Western Oregon Forms" (1978). Dissertations and Theses. Paper 845.

https://doi.org/10.15760/etd.845

This Dissertation is brought to you for free and open access. It has been accepted for inclusion in Dissertations and Theses by an authorized administrator of PDXScholar. Please contact us if we can make this document more accessible: pdxscholar@pdx.edu. 


\title{
A BIOGEOGRAPHICAL STUDY OF CURREMLY IDEMTIFIED OREGON PSEUDOSCORPIONS WITH AN EMPHASIS ON UESTERN OREGON FORMS
}

by

ELIEN MARING BENEDICT

\begin{abstract}
A dissertation aubmitted in partial fulfillment of the requirements for the degree of
\end{abstract}

DOCTOR OF PHILOSOPHY

in

ENUIRONMENTAL SCIENCES AND RESOURCES--BIOLOGY

\section{Portland State University}

1978 
TO THE OFFICE OF GRADUATE STUDIES AND RESEARCH:

The members of the Committee approve the dissertation of

E1len Maring Benedict presented Mav 16.1978.

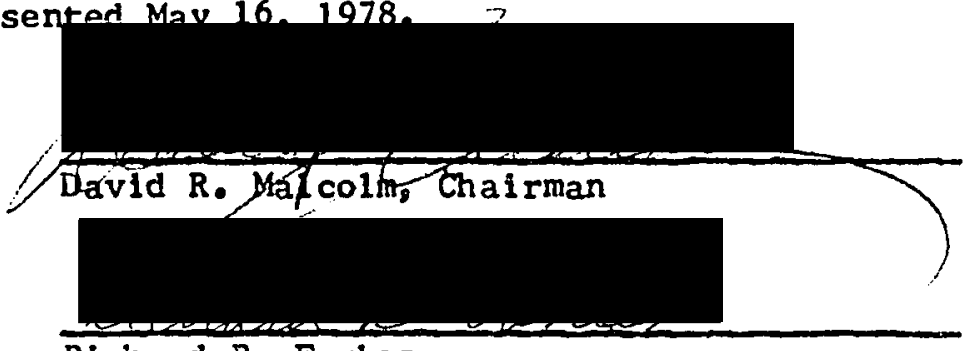

Richard B. Forbes

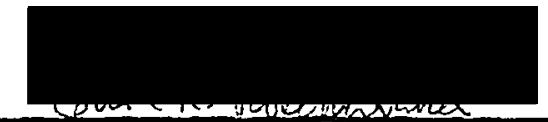

Earl Rosenwinkel

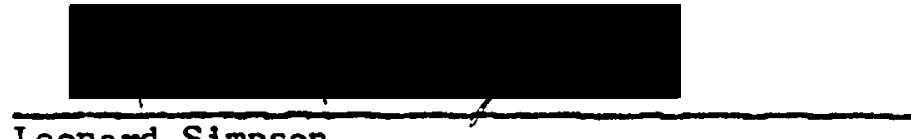

Leonard Simpson

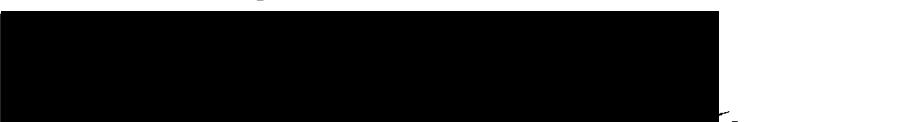

Carl Bachhuber

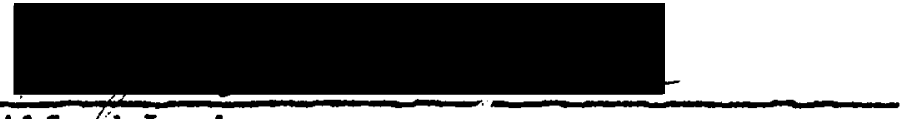

Alfred Levinson

\section{APPROVED :}

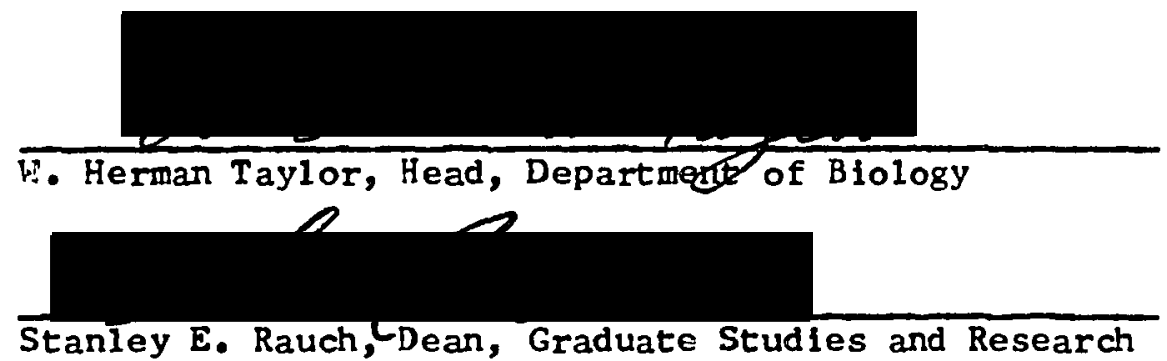


AN ABSTRACT OF THE DISSERTATION OF Ellen Maring Benedict for the Doctor of Philosophy in Environmental Sciences and Resources-Blology presented May $16,1978$.

Titles A Blogeographical Study of Currently Identified Oregon Pseudoscorpions with an Emphasis on Vestern Oregon Forms. APPROVED BY MEMBERS OF THE DISSERTATION COMMITTEE\&

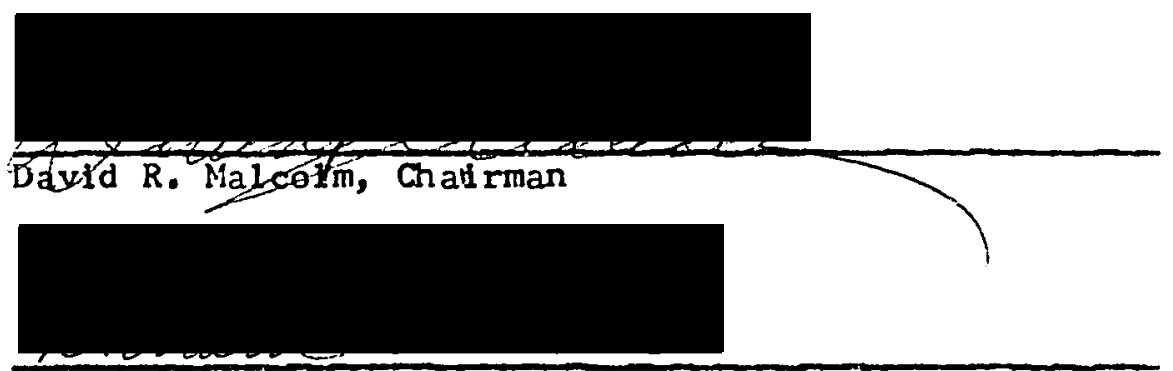
Richard B. Forbes

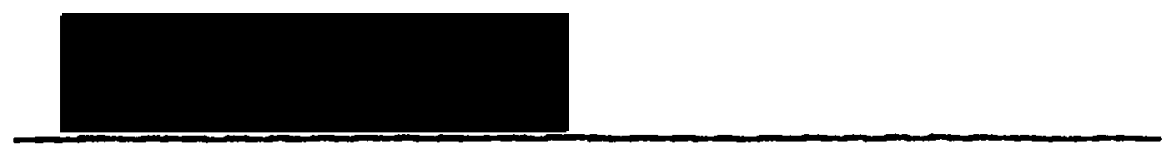

Ear1 Rosenwinkel

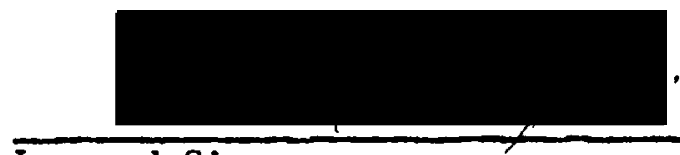

Leonard Simpson

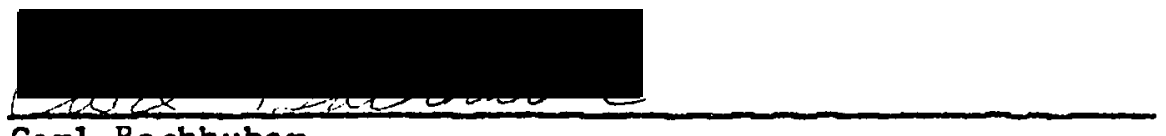

Carl Bachhuber

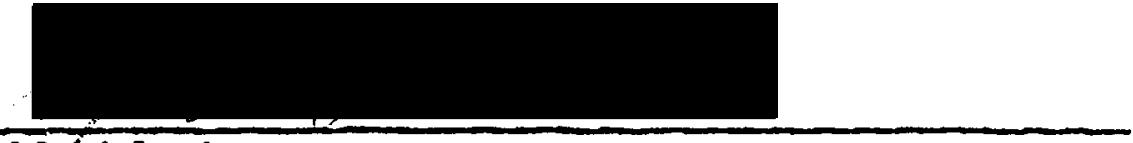

Alfred Levinson 
The blogeography of the 50 currently identifled Oregon species is reported from analyses of data from 2220 Berlese samples collected in a stratified, extensive sampling procedure, and from collection data on several hundred specimens from major private and public collections of pseudoscorpions. Individual species accounts including maps and data relating to geographical and seasonal distribution and habitats are provided, distributional areas and habltat types are categorized, dispersal mechanisms including examples of phoresy are presented and an illustrated key to Oregon species is given. 
ACKNOWLEDGMENTS

I am deeply grateful to Dr. David R. Malcolm, Dean of the College of Arts and Sclences at Pacific University, Forest Grove, and Adjunct Professor of Blology at Portland State University, for guiding my doctoral research. Not only has he supervised my research during my master's and doctoral programs and co-authored a number of systematic papers which serve as the basls for several western North American specles of pseudoscorpions, but he has permitted me free access to the collection, reprints, files and records of the late Dr. Joseph C. Chamberlin. Dr. Chamberlin erected the currently accepted systematic hierarchy of suborders, families and many of the genera during his own doctoral research of the late $1920^{\prime} \mathrm{s}$ at Stanford University. Dr. Chamberlin published 40 research papers on various entomologlcal subjects and amassed among $h$ is other specimens the flrst major collection of Oregon pseudoscorplons; I have been deeply inspired by $h$ is meticulous work.

Although I have not directly borrowed specimens from Dr. $C$. Clayton Hoff of the University of New Mexico, I have had access to thea through the American Museum of Natural History; his many papers between 1945 and 1965 have been invaluable. I am Imeasurably Indebted to Dr. Hilliam B. Muchmore of the University of Rochester who has continuously encouraged my study by answering questians, loaning specimens, co-authoring the redescription of Apochthonius moestus (Banks) and reviewing several of my papers. Mr. Robert 0. 
Schuster of the University of California at Davis has kindly loaned specimens and answered questions. Appreciation is expressed to Drso John Cooke and Norman Platnick of the Amerlcan Museun of Natural History, Drs. Paul H. Arnaud, Jr. and David Rentz of the California Academy of Sclences, Mr. Rod Crawford of the Burke Museum, Dro L. L. Pechuman of Cornell Untversity, Dr. John Unzicker of the Illinols Natural HIstory Survey and Dr. Herbert Levi of the Museum of Comparative Zoology for the loan of valuable specimens. Messrs。 James K1rk (Portland State University), Tom Pogson (Lewis and Clark College) and Dr. Loren Russell (Oregon State UnIversity) have contributed Important specimens. Dr. Russell deterained several of the beetles mentioned in this study.

Special thanks are due Dr. Richard B. Forbes of Portland State University who has acted as my "on-campus" advisor and whose help, advice and encouragement allowed me to continue my study of pseudoscorplons during my doctoral program. I would also like to thank the other professors who served on one or both of ay doctoral committees (thesis or preliminary examination): Drs. Carl Bachhuber, Denzel Ferguson, Alfred Levinson, Byron E. Lippert, Earl Rosemwinkel, and Leonard Simpson. I am Indebted to Dr. Quentin D. Clarkson for helping devise the sampling procedure, to Dr. Robert O. Tinnin for answering questions, and to Dr. Lester Nowman for encouragement. I would like to acknowledge the help provided by Dr. Karl Dittmer, Coordinator of the Environwental Sclences and Resources Doctoral Program and Dean of the College of Sclence; Dr. Earl Fisher, former Head of the Department of Blology, and Dr. H. Herman Taylor, Jr., 
present Head; Mrs. Patricia Moore, Administrative Assistant to the Dean of the College of Sclence; and Mrs. Marjorie Dittmer of the Faculty Women's Organization. During this investigation, research facilities were provided, not only at Portland State University, but at Pacific University by Dr. Malcolm, and at the Malheur Field Station in Harney County, Oregon, by Dr. Ferguson, Director of the Station. Special recognition is due my father, Mr. Charles L. Stephens, who built the 96 Berlese funnels and stands, and who accompanied me on most collecting trips. Thanks are due Messrs. Alan V. Benedict, Earl L. Benedict, Lyle A. Benedict, Mark S. Benedict, John Palmer, Scotty Steeves; and Misses Alice Z. M. Benedict, Ruth E. Benedict, Jan Trzil, Chris Gniewosz, Patricla Daley, Karen Way, Patrlcia Barnhart, Esther H. Gruber and Dr. Yvonne Weber for helping occaslonally in the field, loading funnels or washing jars. I am deeply indebted to Esther Gruber for sharing my interest in soll animals and for preparing two of the maps ( 1 , Appendix II), to Ms. Susan Lindstedt for drawing Figures 1-9, to Mr. Charles V. Larson for drawing the original Oregon map and printing Figures 10 and 11 , and to Ms. Rachel D. Veith for supervising the printing and assembling of the final copyl Dr. Malcolm granted permission for the use of the Chamberlin drawings in Appendices III and IV.

Finally, I wish to express my deepest appreciation to my husband, Ben, for $h$ is continuous encouragement, heip and support. Without the full cocperation of my family this work could never have been completed. 
TABLE OF CONTENTS

PAGE

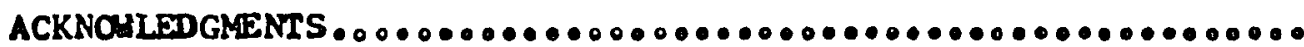

LIST OF TABLES

$\mathbf{x}$

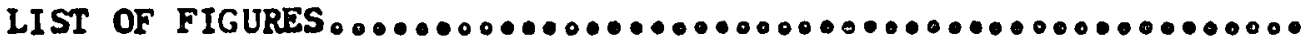

$\mathbf{x i}$

LIST OF MAPS

INRRCDUCT ION॰

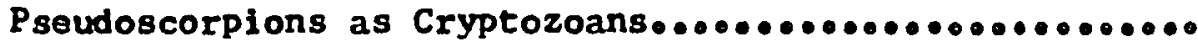

Environmental Implications of this Study॰............

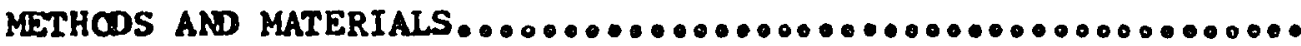

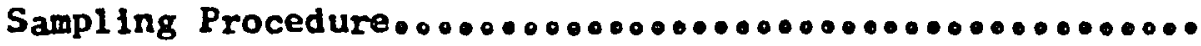

Preparation and Deposition of Specimens...............

SPECIES ACCOUNTS OF OREGON PSELDOSCORPIONS

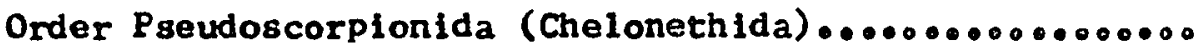

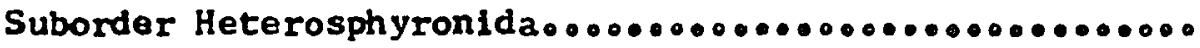

Apochthonlus Apochthon 1us forbes $1 \ldots \ldots \ldots \ldots \ldots \ldots \ldots \ldots \ldots$ Apochehonlus malheuri 000000000000000 .

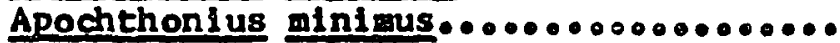
Chthonius (Hesperochthonius) oregonicus....0. v0000000000000000.0. Kleptochthonius (Kleptochthonius)

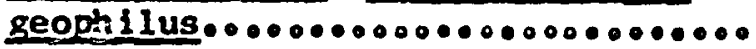


Kleptochthonius (Kleptochthonius) oragonus

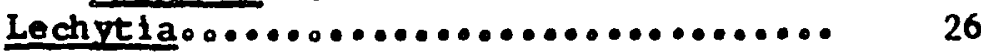

Lechyt la hofflo

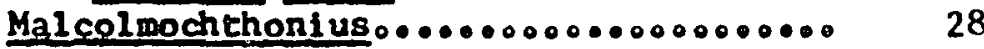

Malcolmochthonlus malcolmi $\cdots 000 \ldots .0 \quad 28$

Malcolmochthonius oregonus...00.... 29

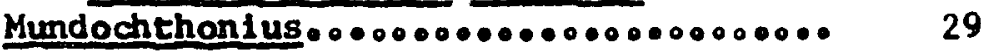

Mundochthonius erosidens........... 30

Mundochthonius nagnus............. 32

Mundochthonius pacificus.......... 32

Neochthonius...................... 33

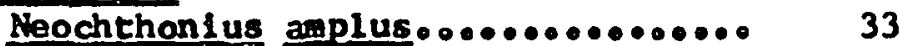

Pseudotyrannochthonlus.............. 34

Pseudotyrannochthonlus gracil18.... 34

Pseudotyrannochthonius incognitus.o 36

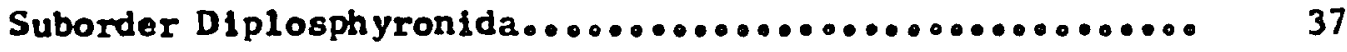

Superfanily Neoblsloldea...................... 38

Family Neobisildae....................... 37

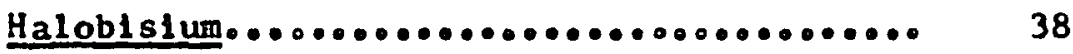

Halobisium occldentale.............. 38

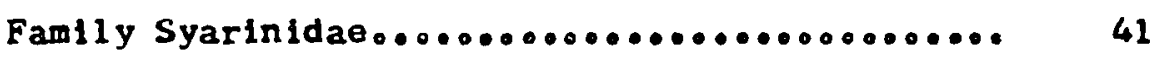

Superfamily Garypoldea...................... 41

Family Garypidae....................... 43

Archeolarca.......................... 43

Archoolarca rotunda....

Larca.......................... 46

Larca chamberlini $000 \ldots \ldots \ldots \ldots \ldots \ldots \ldots \ldots \ldots \ldots \quad 46$

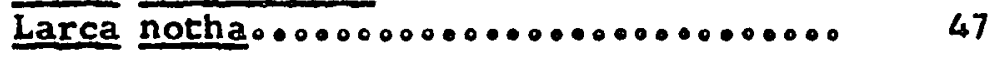

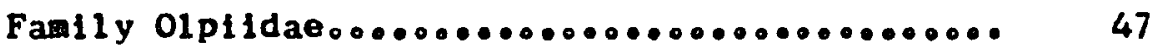

Oreolplum

Oreolpium nywphum.

Psoudogarypinus...................... 49

Pseudogaryplnus Erontal1s............ 51

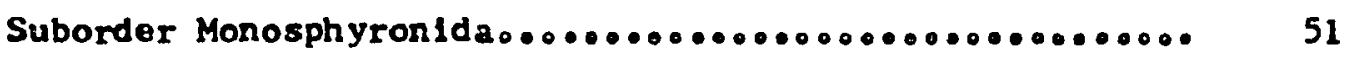

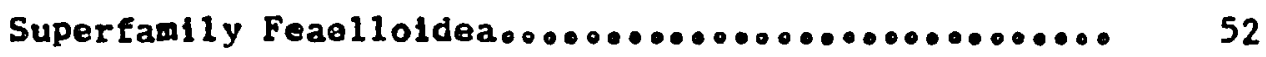

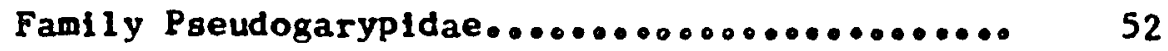




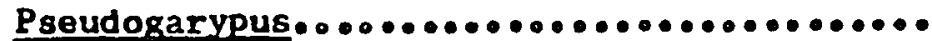

Apochelridium,

Family Chernetidae $\ldots \ldots \ldots \ldots \ldots \ldots \ldots \ldots \ldots \ldots \ldots \ldots \ldots \ldots \circ$

Acuminochernes......................... Acuminochernes crassopalpus............

Dendrochernes...0.......................

Dendrochernes crassus.................

DInocheirus...........................

Dinochelrus slcarlus..................

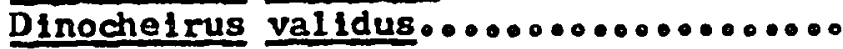

Hesperochernes $\ldots$..........................

Hesperochernes utahensis..............

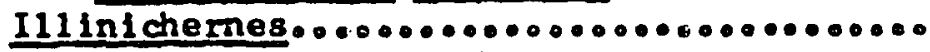

I11inlchernes stephens1............. 72

Lamprochernes............................ 72

Lamprochernes 8p. $\ldots \ldots \ldots \ldots \ldots \ldots \ldots \ldots \ldots \ldots \ldots \ldots$ 73

Lustrochernes....................... 73

Lustrochernes grossus.0.0.0.00......... 73

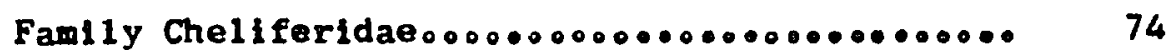

Aspurochelifer......................... 76

Aspurochelifer 11ttlefleldl.......... 76

Chelifer...0.0.0000000000.000000000.0.... 76

Chellfer cancroldes $00000000000000 \ldots \ldots \ldots 078$

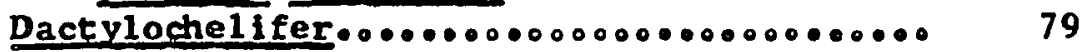

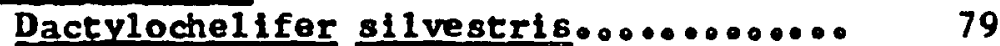

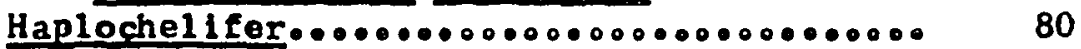

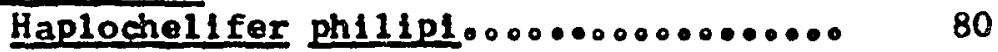

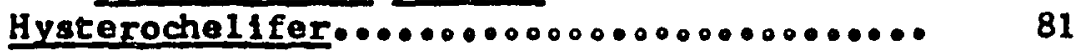

Hysterochel 1 fer fuscipes............ 81

Hysterochelifer proprius $00000000000 \ldots 083$

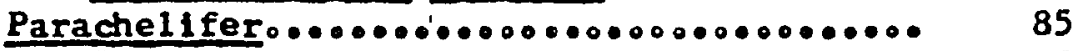

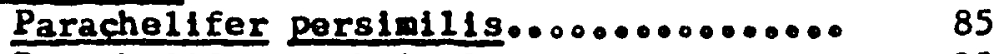

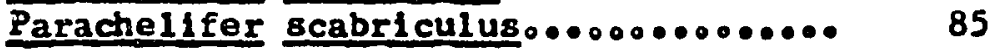


DISTRIBUTIONAL AREAS AND DISPERSAL OF OREGON SPECIES_....... 88

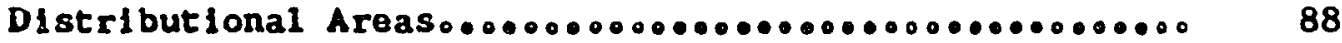

Dispersal of Pseudoscorplons...................... 91

Anclent Origin of Pseudoscorplons_.................... 96

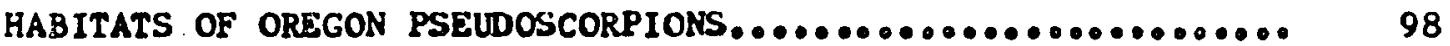

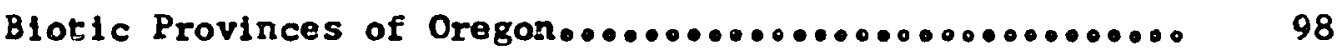

Habltat Relationships of Oregan Species According

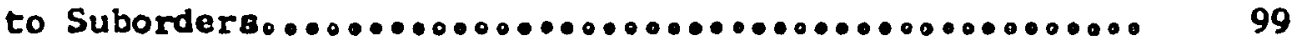

Habltat Specificity of Oregon Pseudoscorplon Speciesoo.o 99

1. Mesic Litter-Epiphyte-Inhabiting Forms.......... 104

2. Semi-Xeric Litter-Inhabiting Forms............. 107

3. Somi-Xeric Litter and Bark-Inhabiting Forms....... 109

4. Bark-Inhabielng Forms....................... 110

5. Tree Hollow-Inhabiting Forms .................. 114

6. Animal Nest and Debris-Inhabiting Forms......... 115

7. Human and Domestic Animal Shelter-Inhabiting

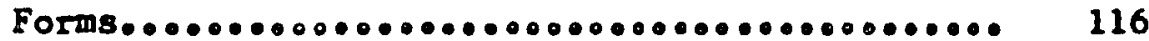

8. Subterranean-Inhabiting Forms................. 118

9. High Tide Zone-Inhabiting Forms................ 120

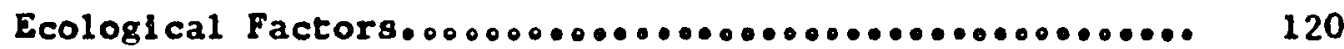

CONCLUSIONS,

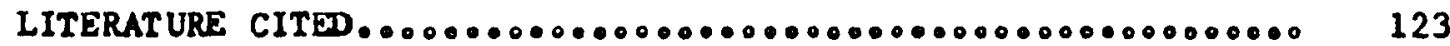
APPENDIX

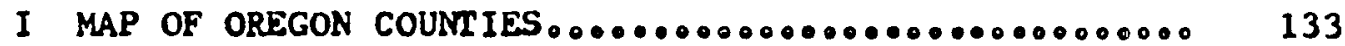

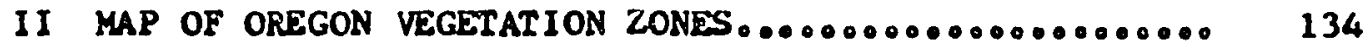

III GENERALIZED DIAGRAM OF A DIPLOSPHYRONII

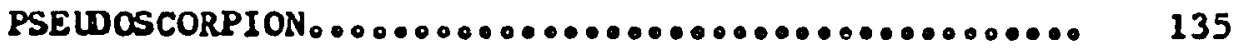

IV IDENTIFICATION KEY TO OREGON PSELDOSCORPIONS $\ldots \ldots \ldots \ldots \ldots 136$ 


\section{LIST OF TABLES}

TABLE

PAGE

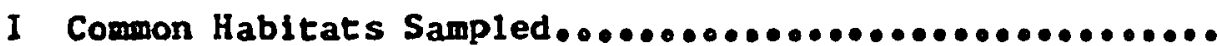

II Comparison of Elevations and Vegetation Lones of Oregon for Two Species of Pseudosarypus

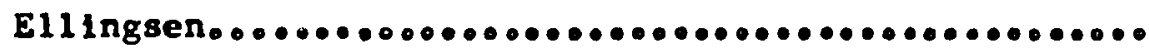

II Oregon Habitats of Heterosphyronid Pseudoscorplons...... 100

IV Oregon Habltats of Diplosphyronid Pseudoscorpions....... 101

V Oregan Habltats of Monosphyronid Pseudoscorplons........ 102 


\section{LIST OF FIGURES}

FIGURE

PAGE

1 Apochthonius occidentalis Chamberlin, a common leaf litter-inhabiting chthonild specles from western

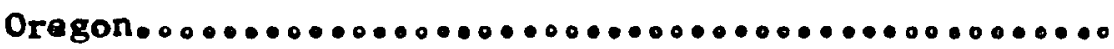

2 Haloblslum occidentale Beler, a noobisild species of

the high tidal zone........

3 Syarinus sp., a leaf litter-inhabiting syarinid

from eastem Oregon $\ldots \ldots \ldots \ldots \ldots \ldots \ldots \ldots \ldots \ldots \ldots \ldots \ldots \ldots \ldots \ldots \ldots \ldots \ldots$

4 Archeolarca rotunda Hoff \& Clawson, a garypid species

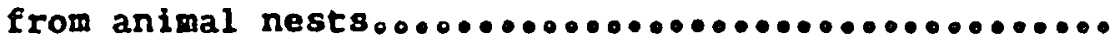

5 Psoudogaryplnus frontalis (Banks), a leaf litter and bark-inhabiting olplid spectes from southwestern

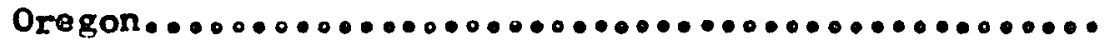

6 Pseudogarypus bicornis (Banks), a leaf litter and

bark-inhabiting pseudogarypid species from Oregon...

7 Apocheiridium fergusoni Benedict, a bark-inhabiting

chelridild species from eastern Oregon.............

8 Illinichernes stephensi Benedict \& Malcolm, a tree

hollow-inhablting chernetid species from western

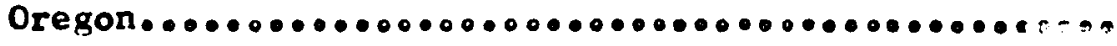

9 Aspurochelifer 11ttlefieldi Benedict \& Malcolm, a leaf

litter-inhabiting cheliferid specles from southern

Oregon 
10 Exfollating bark of Juniperus occidental is Hook...000.0.

11 A laboratory specimen (male) of Hysterochelifer

proprlus Hoff feeding on a collembolan.............. 


\section{LIST OF MAPS}

MAP

PAGE

1 Western Oregon, showing the 45 stratifled sample units

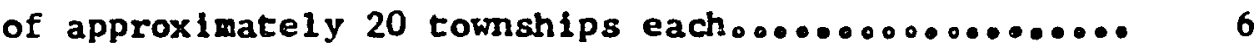

2 Oregon, showing locations of eastern Oregon collections.. 7

3 Reported Oregon localities of heterosphyronid species prior to 1970, Apochthonius occidental1s, Chthonius oregonicus, Kleptochthonlus geophilus, Ko oregonus, Pseudotyrannochthonius incognitus, P. nawe11i.000...

4 Oregon localities reported by Benedict \& Malcolm (1970) for Pseudotyrannochthonius incognitus ( junior synonym) $\ldots \ldots \ldots \ldots \ldots \ldots \ldots \ldots \ldots \ldots \ldots \ldots \ldots \ldots \ldots \ldots \ldots \ldots \ldots \ldots$

5 Reported Oregon locallties of diplosphyronid specles prior to 19718 Microcreagris clngara, Mo columbiana, M. thevenet 1 , Parobisium charlotteae, P. hesperum...o

6 Reported Oregon localities of monosphyronid species prior to 19718 Chelifer cancroldes, Haplochelifer philipi,

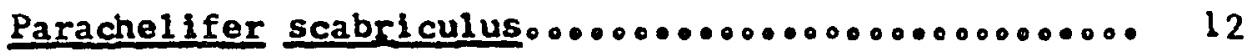

7 Distribution in Oregons Apochthonius forbesi, A. malheuri,

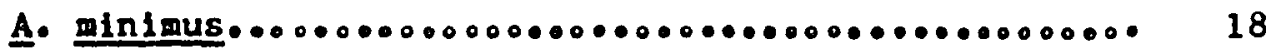

8 Distribution in Oregons Apochthonius occidentalis........ 18

9 Distribution in Oregons Chthonlus oregonicus,

Kleprochthonius geophtlus, K. oregonus........... 25 
10 Distribution in Oregon Lechytla hoffi, Malcolmochthonlus

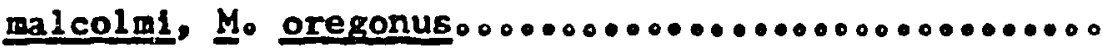

11 Distribution in Oregons Mundochthonius erosidens,

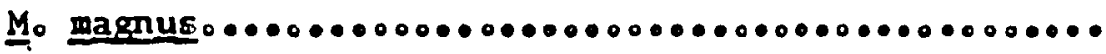

12 Distribution in Oregons Mundochthonius pacificus.........

13 Distribution in Oregons Neochthonius amplus............

14 Distribution in Oregans Pseudotyrannochthonius gracilis,

P. Incognitus

15 Distribution in Oregon: Halobisium occidentale.........

16 Distribution in Oregons Archeolarca rotunda, Larca

chamberlink, Lo notha $\ldots \ldots \ldots \ldots \ldots \ldots \ldots \ldots \ldots \ldots \ldots \ldots \ldots \ldots$

17 Distribution in Oregons Oreolpium nymphum, Pseudogarypinus

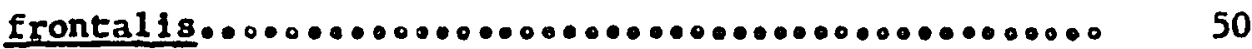

18 Distribution in Oregont Pseudogarypus bicornis.......... 54

19 Distribution in Oregons Pseudogarypus hesperus........000 54

20 Distribution in Oregons Apocheiridium bulbifemorum,

A. fergusoni, A. ferumoldes $\ldots \ldots 00 \ldots \ldots 000000000000$

21 Distribution in Oregon: Apocheiridium granochelum,

A. mormor

22 Distribution in Oregons Acuminochernes crassopalpus,

Dendrochernes crassus $0000000000000 \ldots \ldots \ldots \ldots \ldots 0 \ldots \ldots \ldots \ldots \ldots$

23 Distribution in Oregons Dinocheirus sicarius,

D. validus

24 Distribution in Oregons Hesperochernes utahensis,

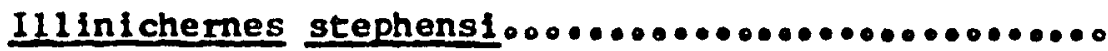


25 Distribution in Oregons Lapprochemes spo,

Lustrochernes grossus $\ldots \ldots \circ \ldots \ldots \ldots \ldots \ldots \ldots \ldots \ldots \ldots \ldots \ldots \ldots$

26 Distribution in Orogons Aspurochelifer littlefleldi,

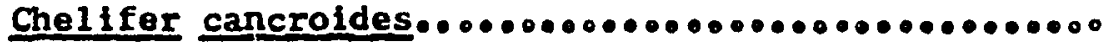

27 Diatribution in Oregons Dactylochelifer silvestris,

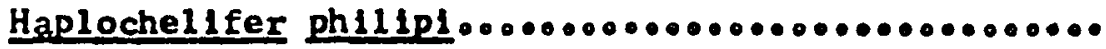

28 Distribution in Oregons Hysterochelifer fuscipes,

H․ propriug,

29 Distribution in Oregon: Parachelifer persigilis,

Po scabrlculus $\ldots \ldots \ldots \ldots \ldots \ldots \ldots \ldots \ldots \ldots \ldots \ldots \ldots \ldots \ldots \ldots \ldots \ldots \ldots \ldots$

30 Distribution in western Mashington, western Oregon and northern Californias Pseudotyrannochthonius incognitus, P. gracilis $\ldots \ldots \ldots \ldots \ldots \ldots \ldots \ldots \ldots \ldots \ldots \ldots \ldots \ldots$ 


\section{INRRODUCT ION}

Although Amerlcans are gradually becoming aware of the complex Interactions of macroscoplc terrestrial and aquatic organisms, similar attention has yet to focus upon the millions of tiny organisms of the so11 and related cryptozolc habitats (van der Drift 1951; Kuhnelt 1961; Savory 1966, 1968; Burges \& Raw 1967; Schaller 1968; Vallwork 1970, 1976). Though not rare, tiny soll animals are often overlooked owing to their cryptic habits. So few basic studies exist, in fact, that it is often necessary to conduct taxonomlc and podological investigations before ecological studies can profitably be initlated (di Castri 1970; van der Drift 1970).

\section{PSEUDOSCORPIONS AS CRYPTOZOANS}

As with many other cryptozoans, very litele is known about the ecelogy of tine nearly 2000 currentiy described specles and subspecles of pseudoscorplons (Chamberlin \&alcolm 1960). These tiny predators occur in a wide diversity of habitats including mosses, leaf litter, so11, decomposing wood, bark, animal nests, domestic animal litter, human habitations and caves (Weygoldt 1969; Muchmore 1973). As a result of their 8120 (body length $1-7 \mathrm{~mm}$ ) and their cendencles to retreat into crevices, pseudoscorplons are generally not seen, Yet, in favorable habltats, they occur in fairly high densities (Ressl \& Beler 1958; Gabbutt \& Vachon 1963; Gabbutt 1967, 1970). Unfortunately, the determination of individuals to species fequires tedious microscope techniques (Chamberlin 1931; Hoff 1949; Lawson 1968; Nelson 1971). This has 
tended to discourage the study of pseudoscorpions; consequently, there are few specialists with adequate knowledge to identify specimens. As a result there are many undescribed or incompletely described species, a fact which contributes to the paucity of ecological studies, including blogeographical investigations of North American species.

Pseudoscorpion faunal studies of large areas of the United States are few in number. Hoff (1958) categorized approximately 160 species from the United States and Canada according to systematic hierarchies and to political subdivision (state or province) of reported localities, but did not include habitat data. Ordinal works with habitat data have been prepared for 1 imited areas or selected habitats of the southeastern states (Lawson 1968), Michigan (Nelson 1975), Illinois (Hoff 1949), New Mexico (Hoff 1959), and Colorado (Hoff 1961), but not for the Pacific Northwest.

Therefore, in 1971 a biogeographical study was initiated in the Pacific Northwest. Oregon was selected as the study area because the topography, climate and biotic communities were especially diverse (Franklin \& Dyrness 1973) and it appeared that the pseudoscorpion fauna would be equally diverse. Prior to the study, only 13 species from three families were recognized from Oregon; currently 50 species from nine families are identifled from the state (Banks 1895; Chamberlin 1929a, 1930, 1952, 1962; Hoff 1950; Malcolm \& Chamberlin 1961; Schuster 1966a; Muchmore 1968, 1975a; Benedict \& Malcolm 1970, 1973, 1977, 1978a, 1978b, 1978c; Benedict 1977, 1978a, 1978b).

This dissertation is a report of this blogeographical investigation and contains individual species accounts, analyses of distributlonal areas and habitats, and records of phoresy. Appendix I provides 
an Oregon map with county names, Appendix II a map with vegetation zones, Appendix II a generalized diagram of pseudoscorpion body form, and Appendix IV an illustrated key to species. For background on Oregon geology, refer to Baldwin (1976) and McKee (1972), on geography to Dicken (1973) and Loy et al. (1976), and on plant names to Peck (1961) and Hitch cock \& Cronquist (1973).

ENVIRONMENTAL IMPLICATIONS OF THIS STUIY

This study provides valuable information not only to specialists of cryptozoan taxa and to soil ecologists, but to monitors assessing the effects of various environmental contaminants in forest and brushlands of Oregon. Pseudoscorplons function as tertiary predators (Cloudsley-Thompson 1958) in cryptozoan environments and, as such, are signiflcant in the enormously complex, dynamic activities involved in soil fertlity processes (Edwards et al. 1970; Cromack et al. 1977; Crossley 1977; NacBrayer 1977; Webb 1977). As noted at the 1967 Paris Symposium on Methods of Study in Soil Ecology (Phillipson 1970), it is practlcally impossible to understand interactions of species unless individuals can be identifled. This study provides the means by which a number of Oregon pseudoscorpion species can be identified, not only by reference to the key (Appendix IV) but by knowledge of their habitats and distribution.

A growing concern is beginning to be expressed about the need for study of the effects of human activities on cryptozoans (Wallwork 1976). Poulson and Kane (1977), in their discussion of ecological diversity and stability, observed that disturbances have multiple effects and are likely to disrupt an ecosystem more than expected. Manley (1969) and Wallwork 
(1976) emphasize that cryptozoans including pseudoscorpions must be studied if nutrient cycles and pesticide interactions in soil ecosystems are to be understood. Such interactions are not wel1-studied in forest habitats (Edwards et al. 1970; Mattson 1977), especially in the western United States. Nor is it really possible to achieve much understanding of the interactions of individual species until more of them become known.

A case in point is the 1974 DDT Tussock Moth Monitoring Program in the Vallowa-Whitman National Forest in northeastern Oregon; the study included a crude census of soil animals in relation to levels of DDT residues (Vestgarth 1975). Since the type of data accumulated in the current blogeographical study had not been gathered for northeastern Oregon, it was not possible to identify soil animals to species, nor to design an effective, efficient and low-cost monitoring procedure from avallable information. Despite the inadequacies of this ploneering monltoring effort in the Pacific Northwest, analysis of data appeared to Indicate that densities of the two pseudoscorpion species decreased in the presence of high DDT residue levels (Gruber \& Benedict 1978). This may be significant in viev of the fact that pseudoscorpions are predators of other cryptozoans, and are considered important in soil arthropod population dynamics, food chain interactions and humificationfertility processes (Manley 1969). 


\section{METHODS AND MATERIALS}

Data for this study were obtained from three basic sources: specimens newly-collected since 1971 from habitats of both randomly and non-randomly selected townships of Oregon, specimens from previously existing private and public collections (see acknowledgments), and specimens reported in the literature.

\section{SAMPLING PROCETURE}

Oregon's size $\left(251,000 \mathrm{~km}^{2}\right)$ required that a system for selecting sampling sites be developed. For this purpose, Oregon was arbitrarily divided into two portions: western Oregon (area west of the crest of the Cascade Mountains) and eastern Oregon (east of Cascade crest). "estern Oregon was further stratifled into 45 units of approximately 20 townships each (Map 1). Within one or two randomly selected townships in each unit, samples were collected from each habitat type (if present) 1isted in Table I; 1093 samples were thus collected. In addition, 637 samples were judgmentally collected from similar or special habitats (e.g., serpentine soll, redwood litter, bogs) in nonrandomly selected townships. Eastern Oregon (Map 2) samples were entirely judgmental and therefore from non-randomly selected townships. Over 2200 Berlese samples from Oregon habitats (Table I) were collected, processed and sorted during the course of this investigation. Pseudoscorpions were recovered from approximately 1400 of the 1730 samples from western Oregon and from approximately 250 of the 490 samples from eastern Oremn. This is the first major investigation 


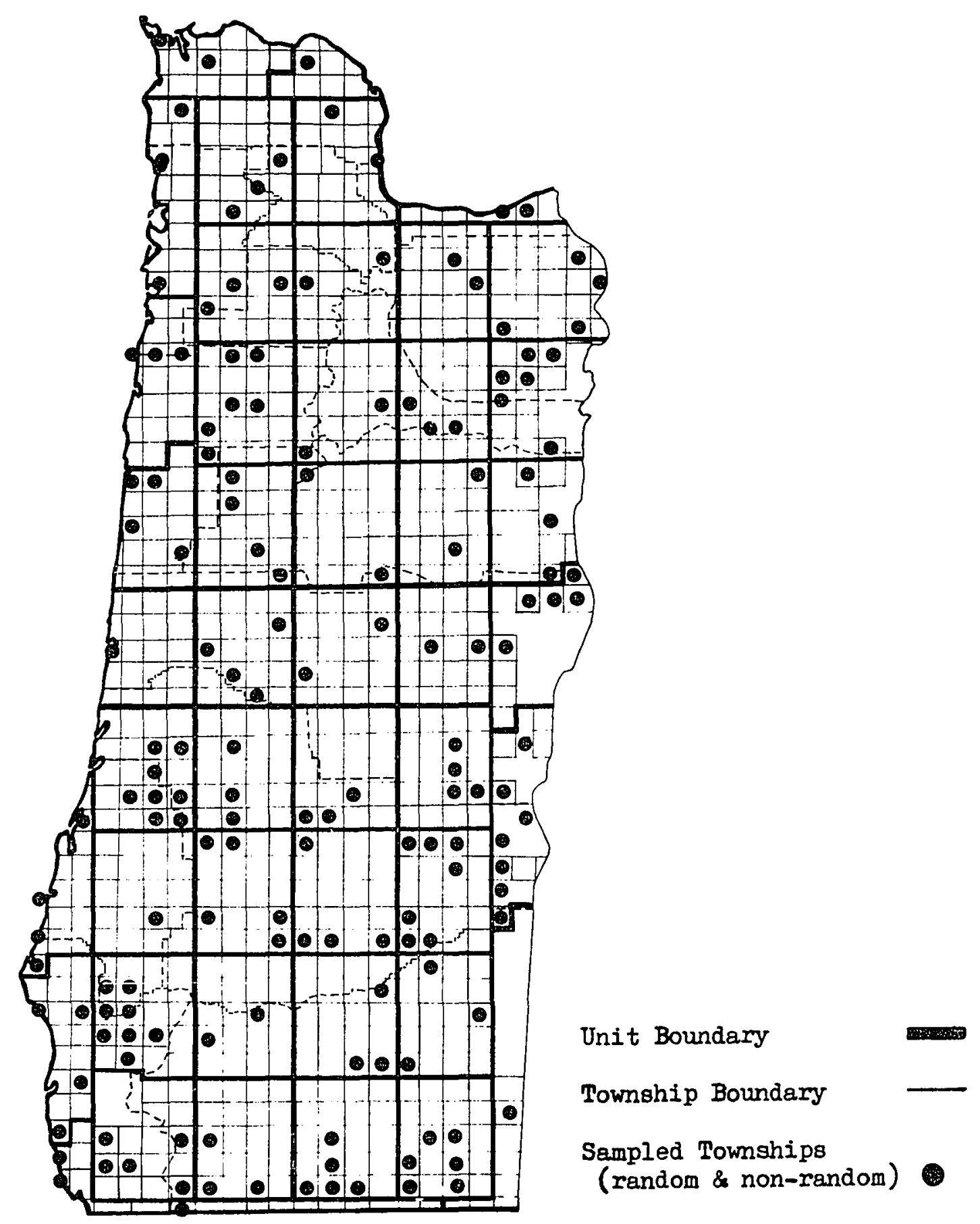

Map 1. Western Oregon, showing the 45 stratified sample units of approximately 20 townships each. 


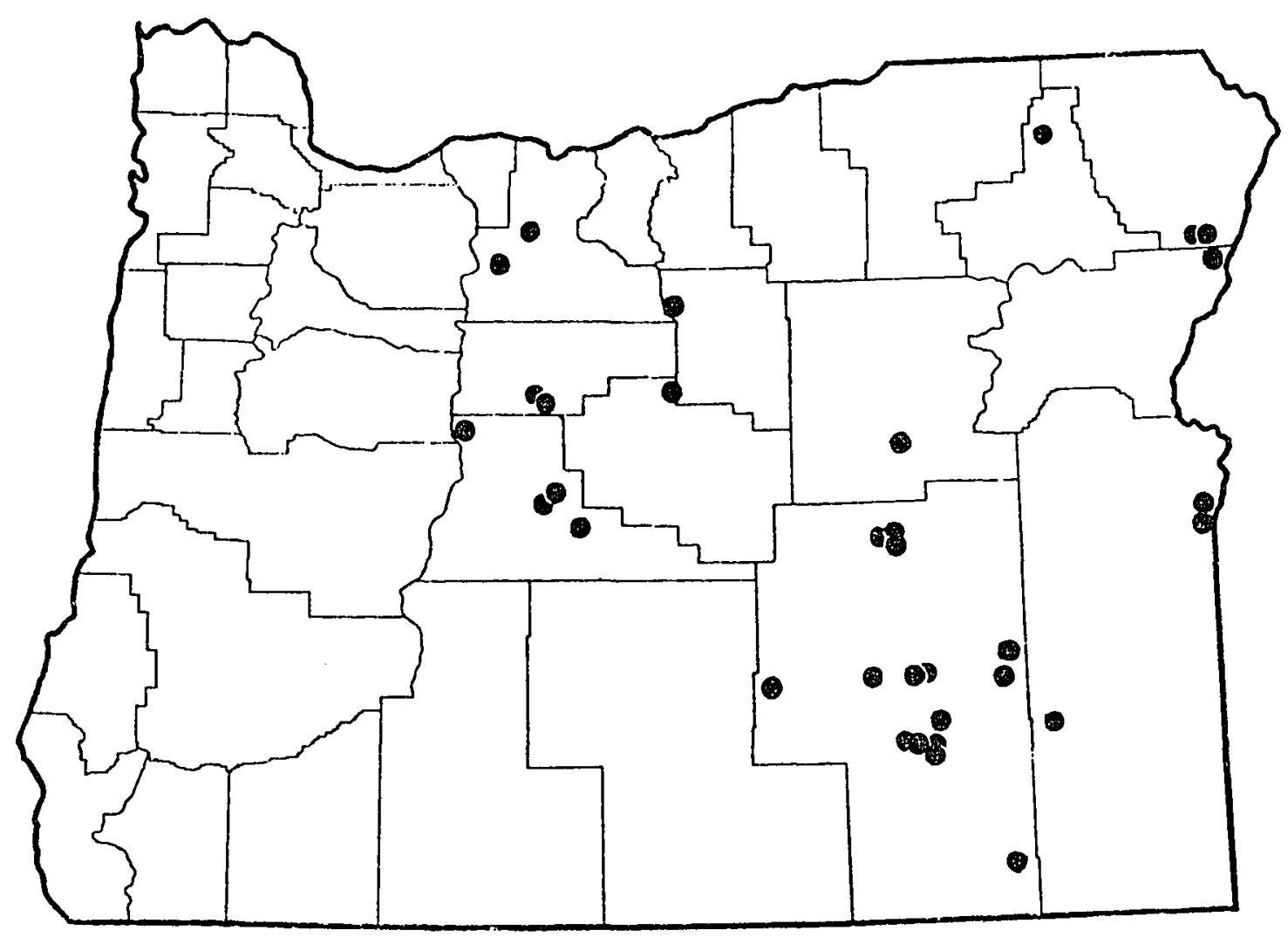

Map 2. Oregon, showing locations of eastern Oregon collections. 
of North American pseudoscorpions which has included stratified random sampling in an area as large as western Oregon $\left(75,000 \mathrm{~km}^{2}\right)$.

TABLE I

COMMON HABITATS SAMPLED

\begin{tabular}{|cc|}
\hline roody piant litter & Bark \\
Deciduous & Living trees \\
Coniferous & Snags \\
Sclerophyllous & Stumps \\
& Logs \\
Fpiphytes & Rotted wood \\
On rocks & Tree hollows \\
On trees & Snags \\
On logs & Stumps \\
& Logs \\
Caves & Animal Nests \\
Under or on rocks & Domestic animal shelters \\
Under boards & Human habitations \\
\hline
\end{tabular}

Preliminary experiments with various samplers of different types and sizes were conducted, as the style used must be determined by the type and uniformity of substrate, the density of organisms and by convenience. Corers and shovels were found to be impractical with materials as diverse as leaf litter, slabs of bark from rotted logs and mosses from tree trunks. Therefore for the purposes of this study, a "sample" was the amount of material gathered by handfuls from a specific microhabitat (e.g., mosses from a single rock, rotted wood from a single log) to fill a plastic bag, $28 \times 15 \times 45 \mathrm{~cm}$ in size. The preliminary experiments revealed that this amount of material from Oregon habitats was 
generally large enough to contain pseudoscorpions if they occurred, and yet was small enough to handle conveniently along with 20 or more similar bags of materials from a single collecting trip.

PREPARATION ANU DEPOSITION OF SPECIMENS

Organisms from samples were heat-extracted for three or four days in $30 \mathrm{~cm}$ diameter, controlled draft Berlese funnels (Wallwork 1970) Eitted with 25-watt 1 ight bulbs. Pseudoscorpions were (according to systematic status of the taxon) either dissected, mounted on microslides in Hoyer's medium and measured (Chamberlin 1931; Benedict \& Malcolm 1977), or preserved in alcohol and identified under a stereomicroscope. Pseudoscorpions are deposited in a reference collection of the American Niseum of Natural $\mathrm{History}$ and in the Benedict-Chamberlin-Malcolm Collection.

Numerous other cryptozoans were extracted in the Berlese residues and have been sent to the following specialists: Chilopoda to Andrew Weaver (College of Wooster); Diplopoda and Opiliones to William Shear (Hampden-Sydney College); Coleoptera to Stewart Peck (Carleton College), Roberi Schuster (University of California at Davis), Loren Russell (Oregon State University), and the Canadian Museum; Araneida, in part, to llerbert Levi (Museum of Comparative Loology, Harvard) and Wilis Gertsch (Portal, Arizona); Acari, in part, to G.W. Krantz (Oregon State University); unsorted organisms to the Fleld Museum of Natural History. From these specimens, a number of range extensions into Oregon and new species have already been described (Gertsch 1973; Shear 1973, 1974, 1975). 
SPECIES ACCOUNSS OF OREGON PSEUDOSCORPIONS

When this study began in 1971 , only 13 species of three families were reported from Oregon; Maps 3-6 show Oregon localities reported prior to 1971. Banks (1895) reported the first two species, Mierocreagris theveneti (Simon) from Portland and Astoria (Map 5) and Parachelifer scabriculus (Simon) from Hood River (Map 6). Collidge (1908) included only these two species from Oregon in his list of North American species. The third species, Apochthonius occidentalis Chamberlin (Map 3), has the distinction of belng the first species to be described with an Oregon type locality (Chamberlin 1929a). Parobistum hesperum (Chamberlin) from Cannon Beach (Map 5) was the second species described with an Oregon type locality (Chamber1in 1930). In the same paper, Chamberlin (1930) also reported Microcreagris clngara Chamberlin from Lane County (Map 5), although Hoff (1958) later considered tt to be a doubtful species for Oregon. In the $1950^{\prime} \mathrm{s}$, Hoff (1950) reported the cosmopolitan speciee Chelifer sancroides (L.) from two Oregon counties (Map 6), and Chamberlin (1952) reported Haplochelifer philipi (Chamberlin) from four Oregon countles (Map 6). then Hoff (1958) published his 1 ist of North American species these records were the only ones reported from Oregon. Oregon species were so little known that Hoff included only one among the seven species Iisted from Washington, two among the five from Idaho, two among the three from Nevada, and four among the 49 from California. Of these, C. cancroides and $\underline{H}$. philipl were known from all but Washington. 


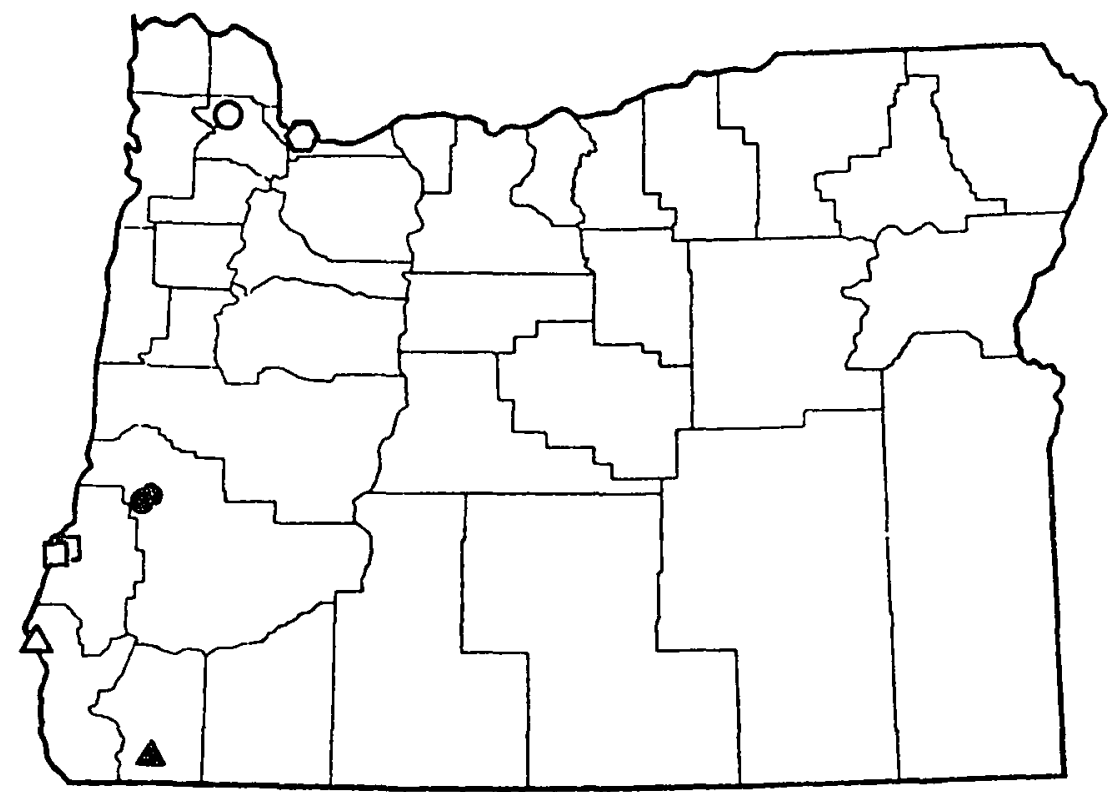

Map 3. Reported Oregon localities of heterosphyronid species prior to 1970; Anochthonius occirentalis 0 , Chthonil:s oregonicus $\square$, Kleptochthonius reophilus $\Delta$, K. orezonus $\mathbf{A}$, Pseudotyrannochthonius incognitus P. newelli 0 .

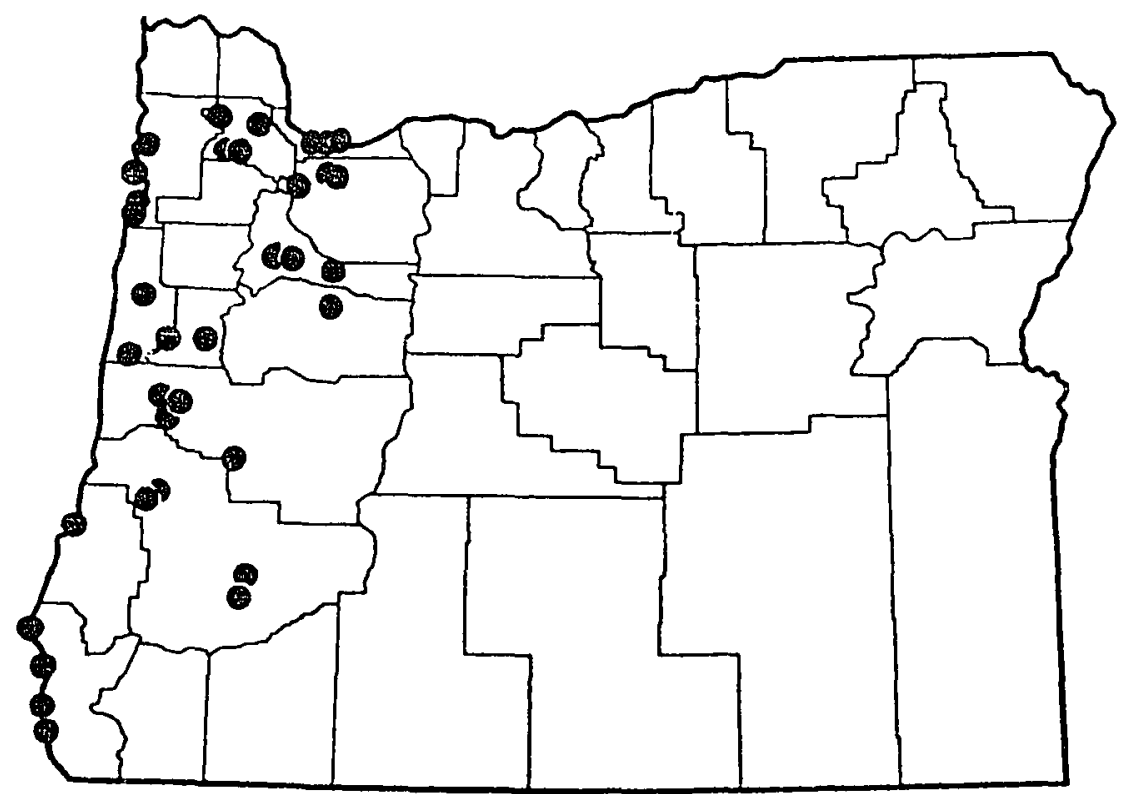

Map 4. Oregon localities reported by Benedict 8 Malcolm (1970) for iseucint:rannochthonius incognitus (‥ newe11i, junior symonym) 


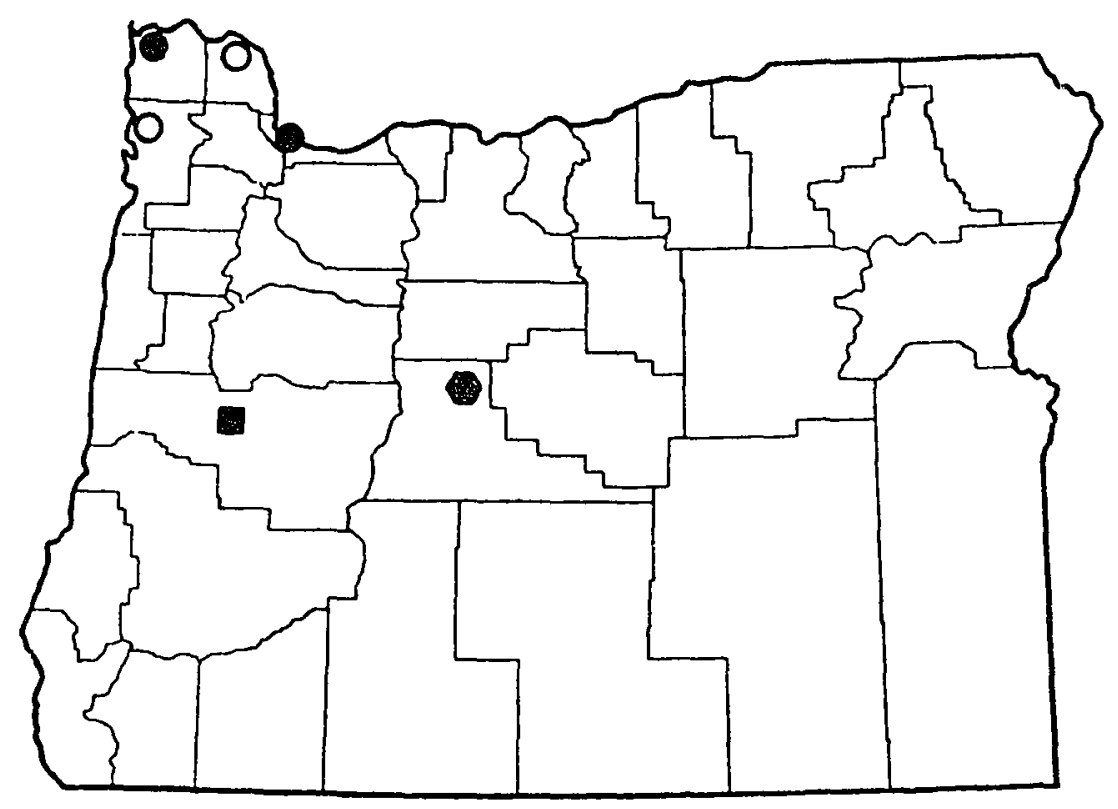

Map 5. Reported Oregon localities of diplosphyronid species Mrior to 1971: Microcreagris cingara , M. columbiana $\mathrm{O}$, 11. theveneti , Parobisium charlotteae,$\underline{\underline{P}}$ hesperum 0 .

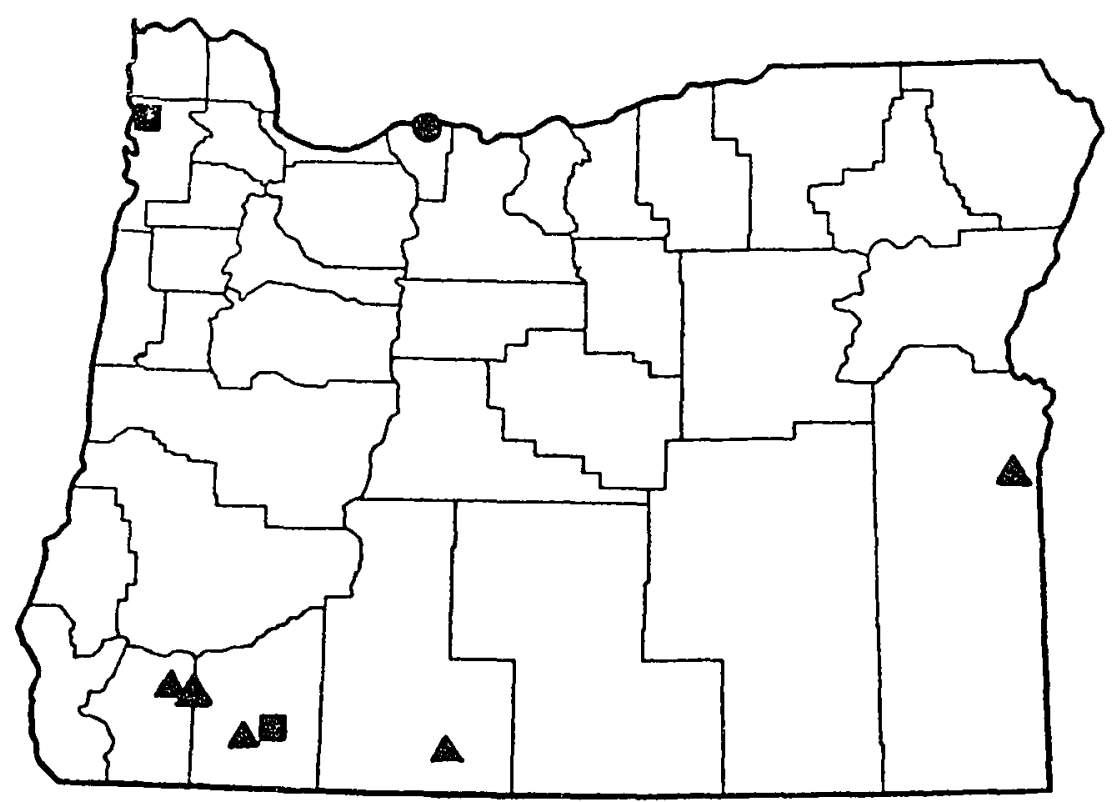

Map 6. Renorted Oregon localities of monosphyronid species; prior to 1.971: Chelifer cancroides , Uaplochelifer philipi - Parachelifer scabriculus . 
During the $1960^{\circ}$ s, seven additional species were described with Cregon type localities (Maps 3-6), Kleptochthonius (Kleptochthonius) oregonus Malcolm and Chamberlin (1961), … (…) geophlis Malcolm and Chamberlin (1961), Parobisium charlotteae Chamberlin (1962), M. columbiana Chamberlin (1962), Pseudotyrannochthonius incognitus (Schuster) (1966a), P. newe111 Muchmore (1967a) and Chthonius (Hesperochthonius) oregonicus Muchmore (1968). In 1970, Benedict and Malcolm recognized $\underline{P}$. newel11 as a junior synonym of $\underline{P}$. incognitus and reported the species from more than 30 Oregon localities (Map 4). My cursory examination in 1971 of Oregon specimens from the Chamberlin-Malcolm Collection indicated that the Oregon fauna would probably consist of approximately 30 species when all specimens were identified. This estimate was consistent with the number of species Iisted at that time for other areass 49 species from Californla (Hoff 1958), 39 from New Mexico (Hoff 1959), 30 from Colorado (Hoff 1961), 26 from Illinois (Hoff 1949), 29 from Michigan (Nelson 1971), and 18 from leaf litter habitats of the southeastern states (Lawson 1968). The analyses since 1971 of Oregon specimens from all sources have revealed at least twice the expected number of species.

The exact number of Oregon species is unknown at the present time as most Oregon localities have not been intensively sampled nor have all the collected specimens been determined to species. In order to Identify most Oregon species, it has been necessary to examine and measure the type series and often hundreds of other spectmens from many states (Benedict \& Malcolm 1970, 1973, 1974, 1978a, 1978b, 1978c, 1978d; Muchmore \& Benedict 1976; Benedict 1977, 1978a, 1978b). Consequent1y, 
considerable systematic work involving Oregon taxa remains. Several "specles", even though distinct taxa, can be discussed only under generic names. Approximately 12 specles of the superfamily Neobisioidea present systematic problems beyond the scope of this study, and cannot be treated under separate species accounts. Despite systematic difficulties, 21 species have been reported from Oregon since 1971 (Benedict \& Malcolm 1973, 1977, 1978a, 1978b, 1978c; Muchmore 1975a; Benedict 1977, $1978 \mathrm{a}, 1978 \mathrm{~b}$ ) as a direct result of this study. Sixteen additional species are being reported for the first time in this work, bringing the total identified species from Oregon to 50.

The following species accounts include avallable data on geographicai distribution, habitats, seasonal distribution and comments about systematic aspects of taxa. Manley's (1969) precedent for Mich1gan species is followed in listing months during which adults and/or nymphs were collected. For most taxa insufficient data exist to draw conclusions about seasonal distribution of life stages. Thus, it should not be assumed that adults or nymphs are absent during unlisted months for which collections may be lacking.

\section{ORDER PSELDOSCORPIONIDA (CHELONETHIDA)}

This arachnid order includes approximately 2000 described species and subspecies (Chamberlin \& Malcolm 1960; Savory 1964). These species have been assigned to three suborders and 20 families (Chamberlin 1931; Beler 1932a, 1932b; Weygoldt 1969) distributed throughout the world. Fifty species are Identified from Oregon. 
SUBORDER HETEROSPH YRONIDA Chamberl in 1929

This suborder is represented in the United States by two families, Tridenchthonidae Balzan and Chthonildae Hansen, both of the superfamlly Chthonioldea Chamberlin.

\section{SUPERFAMILY CHTHONIOIDEA Chamberlin 1929}

Only the family Chthonildae is reported from Oregon.

\section{FAMILY CHTHONIIDAE Hansen 1893}

Chthonilds (Fig. 1), assigned to more than 35 genera throughout the world and represented by eight genera in Oregon (Maps 7.14), are cosmopolitan in distribution except for the extreme northern and southern latitudes (Chamberlin 1931). Chthonilds, as inhabitants of moist soll and litter, are probably the most common pseudoscorpions in western Oregon, both in terms of numbers of animals and of species. This, no doubt, is related to the number of relatively moist habitats in the extensive forests, woodlands and brushlands. Prior to 1971, only five of the currently recognized chthonild species were reported from Oregon (Maps 3-6): Apochthonius occidentalis (Fig. 1), Klepthochthontus oregonus, $K$. geophilus, Pseudotyrannochthonius incognitus and Chthonius oregonicus. Eleven additional chthonild species have been identified as a result of this study. These 16 spesies, discussed under the species accounts below, are separable by the characters in the key.

\section{Apochthonius Chamberlin 1929}

Although a specimen of $\underline{A}$. occidentalis was collected in Oregon as 


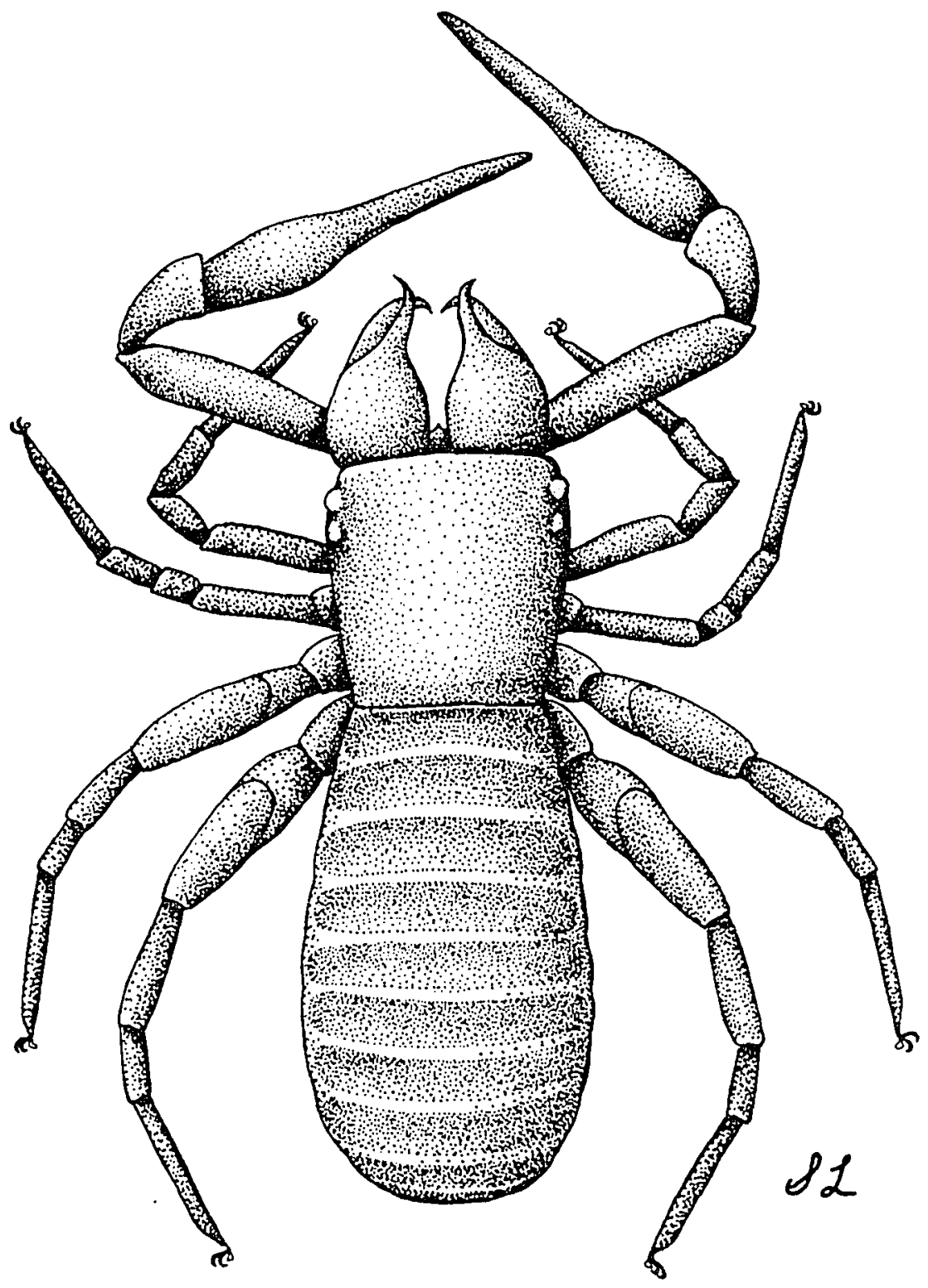

Figure 1. Apochthonlus occidental is Chamberilin, a comson leaf Iltter-inhabiting chthonild specles from western Oregon. (Body longth $1-2 \mathrm{~m}$ )。 
early as 1921 (Chamberiin 1929a) and specimens of Apochthonius occur in nearly every western Oregon leaf litter sample (at elevations 0-1200 m), this genus was reported previously from Oregon from fewer than two dozen specimens (Chamber1in 1929a; Benedict \& Malcolm 1973; Benedict 1978b). This situation stems not from low population densities as suggested by Schuster (1966b) but from an impasse resulting from inadequate species descriptions, poor preparation of certain type specimens, and a lack of data concerning intraspecific and interspecific variations. Even though recent studies (Benedict \& Malcolm 1973; Muchmore \& Benedict 1976; Muchmore 1967b, 1976) solved several systematic problems, most noncavernicolous species of Apochthonius need redescribing. At the present time, four species can be reported from Oregon.

Apochthonius forbesi Benedict (in press)

Geographical distribution. Oregon (Miap 7). This species is known only from the sink in which Charcoal Cave No. I is located. The sink, approximately $10 \mathrm{~m}$ deep by $25 \mathrm{~m}$ wide and $45 \mathrm{~m}$ 1ong, is one of a series of collapsed segments of the Arnold Lavatube System (Greeley 1971).

Habitat. Leaf 1itter. A. forbesi inhabits the moss-litter layer beneath mountain spray (Holodiscus dumosus (Hook.) Heller) and squaw currant (Ribes cereum Dougl.), which grow on the floor of Charcoal Sink. Interestingly, not only do the semi-mesic sinks of the Arnold System contain different shrub species than the surface above, but different pseudoscorpion species were collected from the two levels. A. Eorbesi and Syarinus sp. inhabit the sink, while Dactylochelifer silvestris Hoff and Haplochelifer philipi inhabit the semi-xeric litter beneath ponderosa pine (Pinus ponderosa (Doug1. ex. Loud॰)) and green manzanita 


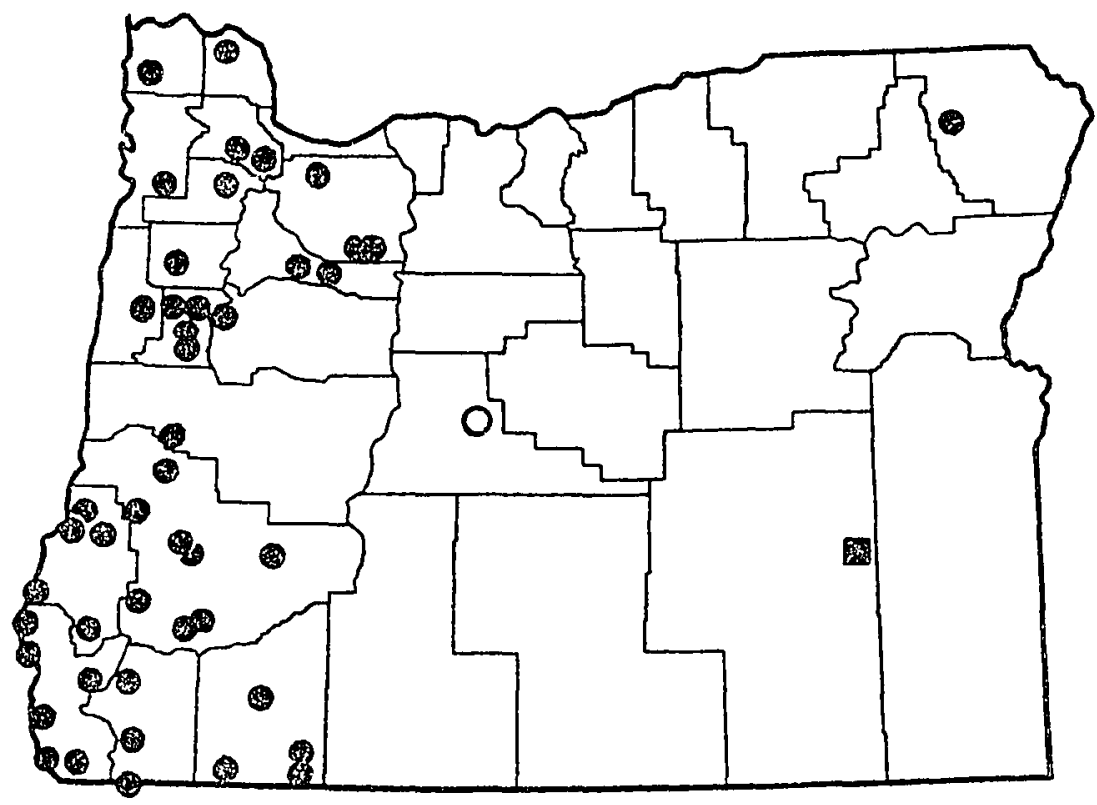

Map 7. Distribution in Oregon: Apochthonius forbesi 0 , A. malheuri , A. minimus

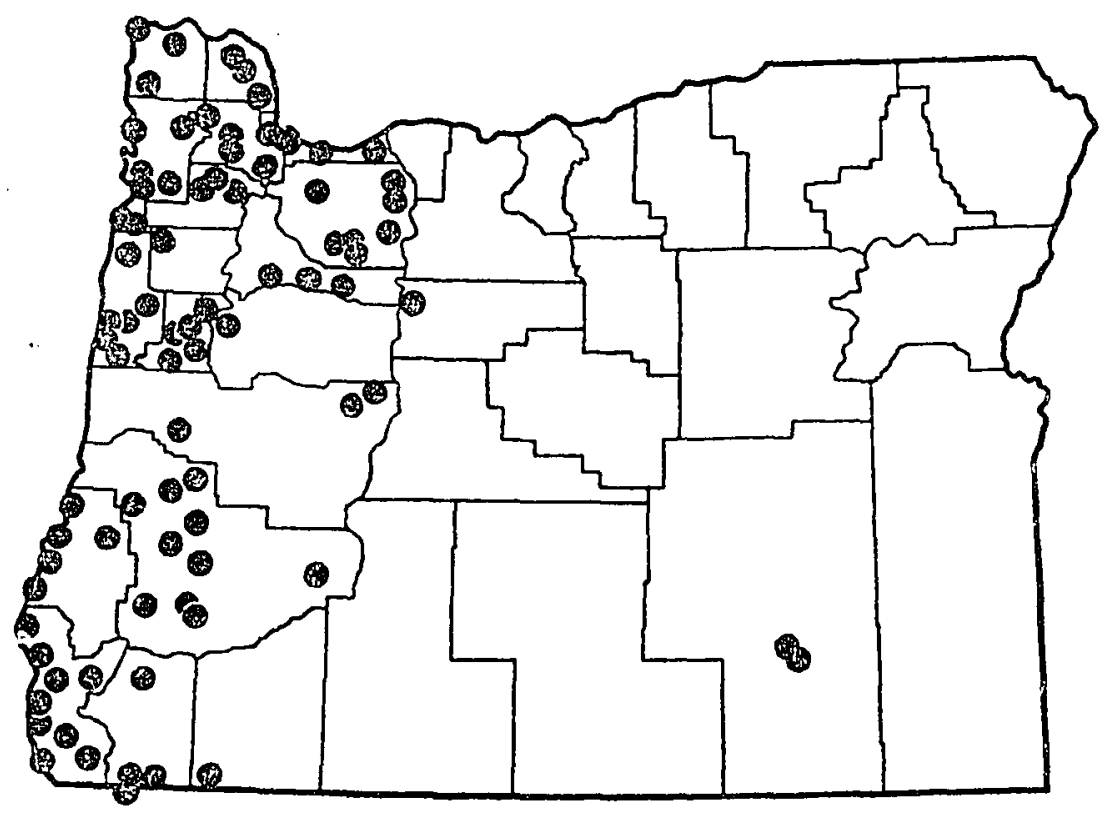

Map 8. Distribution in Oregon Apochthonius occidentalis . 
(Arctostaphylos patula Greene) of the surface. The area, located at an elevation of $1385 \mathrm{~m}$, receives an average annual precipitation of about $320 \mathrm{~mm}$ and is ectonal between open stands of ponderosa pine forest and sagebrush (Artemisia spp.) shrub-grasslands (Franklin \& Dyrness 1973).

Seasonal distribution. Oregon adults of A. forbesi were collected in June; nymphs are unknown. Remarks. See Benedict (1978b) for a detailed description of this specles. Although the total specialization of A. forbesi for subterranean existence is not as marked as that observed for many cavernicolous species of the genus (e.g., A. malheuri Benedict \& Malcolm), it is still apparent. In contrast to other Oregon leaf litter specles of the genus, A. Eorbesi has somewhat less pigment and/or thinner cuticle, weaker eyes, slimmer appendages and greater size.

\section{Apochthonius malheuri Benedict \& Malcolm 1973}

Geographical distribution. Oregon (Map 7). This species is known only from Malheur Cave, a unitary lavatube nearly $1000 \mathrm{~m}$ in length, which is located in semi-arid Harney County at an elevation of $1220 \mathrm{~m}$.

Habitat. Cave. Specimens were recovered from we11-rotted wood and debris removed from crevices and undersurfaces of rocks in the humid deep Twilight to True Dark Lones (Howarth 1973) between 200 and $365 \mathrm{~m}$ downtube from the entrance (Benedict \& Malcolm 1973). Malheur Cave is unusual among lavatubes of the Pacific Northwest in that it contains a cool-thermal lake (Palmer 1975) with a maximum measured depth of $7 \mathrm{~m}$. Consequently, the cave is up to $10^{\circ} \mathrm{C}$ warmer in the True Dark Zone (Benedict et al. 1977) than the expected temperature of $7.8^{\circ} \mathrm{C}$, 
the average annual temperature of the area. The area averaged $290 \mathrm{~mm}$ of precipitation annual1y.

Seasonal distribution. Oregon adults were collected in August and September, nymphs of all three stages in September and October. Remarks. See Benedict and Malcolm (1973) for a detailed description of A. malheuri. This is the first species of Apochthonius reported from a cave west of Missouri and Arkansas. It exhibits typical troglobitic modifications (Chamberlin \& Malcolm 1960) of attenuation, giantism, depletion of pigment and loss of photoreceptors (Benedict \& Malcolm 1973). Malheur Cave also contains three apparently endemic, aquatic, cavernicolous invertebrate species, the flatworm Kenkia rhychida Hyman, the amphipod Stygobromus hubbsi Shoemaker and an undescribed isopod of the genus Asellus (L. Fleming, pers. comm.).

\section{Apochthonius mirimus Schuster 1966}

Geographical distribution. Oregon (Map 7), Washington. This species was reported previously from two localitiess the olympic peninsula of northwestern Washington (Schuster 1966b) and Douglas County, Oregon (Benedict \& Malcolm 1973). It is now known from 76 additional Oregon collections taken at elevations from 0-1675 m. Although A. minimus was collected as high as $1675 \mathrm{~m}$ on Nt. Ashland, it is more common in the lowlands from $0.610 \mathrm{~m}$.

Habitats. Leaf litter and mosses. A. minimus occurred in samples of litter from beneath such dominant species as bigleaf maple (Acer macrophyllum Pursh), red alder (Alnus rubra Bong.), Douglas-fir (Pseudotsuga menziesil (Mirb.) Franco), western hemlock (Isuga heterophy1la (Raf.) Sarg•), Oregon white oak (Quercus garryana Dougl.), 
Callfornta black oak ( $Q$. kelloggil Newb.), canyon live oak ( 9 . chrysolepis Liebm.), Oregon ash (Fraxinus latifolia Benth.), black cottonwood (Populus trichocarpa Torr.\& Gray), California laurel (Umbellularia callfornica (Hook。\& Arn.) Nutt.), Sitka spruce (Picea sitchensis (Bong.) (arr.), ponderosa pine, lodgepole pine ( sugar pine ( $\underline{P} \cdot$ lambertiana Douglo), grand fir (Abies grandis (Dougl.) Lindl.), incense cedar (Libocedrus decurrens Torr.), and madrone (Arbutus menziesil Pursh). Chamberlin (unpubl. record), also collected it from "under board, edge of marsh at north end of Coos Bay." The single known eastern Oregon collection, also by Chamberlin (unpubl. record), was taken in Wallowa County (approx. $910 \mathrm{~m}$ elev.) from "bark rotting pine stump."

Seasonal distribution. Oregon adults were collected every month of the year. Nymphs, while present, were not sorted separately. Remarks. This species should be redescribed from large serles of specimens from throughout its range. When A. minimus and A. occidentalis occur in the same collection, adults of A. minimus are one-third smaller than those of $A$. occidentalis. The coxal spines also differ (see key).

Apochthonius occidentalis Chamberl in 1929

Geographical distribution. Callfornia, New Mexico, Oregon (Map 8), Washington. This species has veeñ reported previously, under this name, only from Portland, Oregon (Chamberlin 1929a). However, my examination of several hundred specimens of Apochthonius, including the types of nearly every described species, reveals that $\underline{A}$. intermedius Chamberlin (1929b) from Friday Harbor, liashington; A. magnanimus Hoff (1956a) from San Miguel and Santa Fe Counties, New Mexico; A. Maximus Schuster (1966b) 
Erom northern California; Apochthonius sp. (Benedict \& Malcolm 1970) from northern California, western Oregon and western Washington; and Apochthonius sp. (Muchmore \& Benedict 1976) from southeastern Oregon, all share a common range of variation in the expression of morphological characteristics and are, therefore, synonymous. Since $\underline{A}$. occidentalis (Chamberiin 1929a) has priority over A. intermedius (Chamberlin 1929b), the taxon is rightfully named A. occidentalis.

Oregon specimens are known from every county west of the Cascade Mountains and from two counties east of the crest. The species occurs in Oregon at elevations from $0-1700 \mathrm{~m}$.

Habitats. Leaf litter, mosses. In western Oregon, A. occidentalis is exceedingly common in the litter-epiphyte layer associated with red alder, white alder (Alnus nhombifolia Nutt.), bigleaf maple, vine maple (Acer circinatum Pursh), black cottonwood, Oregon oak, Oregon ash, Douglas-fir, western hemlock, Sitka spruce, western white pine (Plnus montlcola Dougl. ex D. Don), ponderosa pine, Jeffrey pine (‥ jeffreyi Grev. \& Balf.), lodgepole pine, sugar pine, Port Orford cedar, western red cedar (Thuja plicata Donn), canyon live oak, madrone, $\tan$ oak (Lithocarpus densiflorus (Hook。) Nutt, ex T. \& G.), California laurel, manzanita (Arctostaphylos spp.), silktassel (Garry eliptica Doug1.), salal (Gaultheria shallon Pursh), and scotch broom (Cytisus scoparius (I.) Link). A. occidentalis even occurs in the 1 it ter-strewn grasses and in clearings overgrown with bracken fern (Pteridium aguilinum (L.) Kuhn). It lnhabits sandy, very shallow litter beneath low, deformed lodgepole pines which grow within sight of the Pacific Ocean. It was recovered from samples of mosses and lichens growing on 
bark and on rocks, debris from the hollow of a bigleaf maple tree, bark attached to a drift log, a pack rat (Neotoma sp.) nest in an old shed and another pack rat nest on the ground in a Douglas-fir forest. In eastern Oregon, $\underline{A} \cdot$ occidentalis was recovered from a mixed 1itter sample from Paclfic silver fir (Ables amabilis (Dougl.) Forbes) and mountain hemlock (Tsuga mertensiana (Bong•) Carr.) near Clear Lake in Wasco County. It was also taken in two samples of leaf litter from chokecherry (Prunus virginiana $I_{0}$ ) and mountain spray growing in riparian communities of the Blitzen River drainage on the western slope of Steens Mountain at $1220 \mathrm{~m}$ and $1700 \mathrm{~m}$ elevation.

Seasonal distribution. Adults were collected from western Oregon during every month of the year, often 20 to 30 in a single sample. Nymphs, especially common during summer months, were collected frequently in the same samples with adults but were not sorted separately. Remarks. A detailed redescription, complete with measurements and figures illustrating intraspecific variation, is in manuscript. See remarks under $\underline{A}$. minimus for information about separating $\underline{A}$. occidentalis from A. minimus.

\section{Chthonius C. Koch 1843}

One species of this genus is reported from Oregon (Muchmore 1968). See Muchmore (1968) and Lawson (1968) for descriptive detalls of the genus.

Chthonius (Hesperochthonius) oregonicus Muchmore 1968

Geographical distribution. Oregon (Map 9). This specles has been reported previously from two localities in Coos County, Oregon (Muchmore 
1968). Now it is known from one additional collection from Charleston (Coos County). A11 known specimens are from localities at elevations near $0 \mathrm{~m}$ in the Sitka Spruce Zone.

Habitats. Leaf litter. Earlier records lacked habitat data (Muchmore 1968) but my specimen came from a sample of mixed leaf litter of Sitka spruce, Port Orford cedar and red alder.

Seasona1 distribution. Adults were collected in April and September; nymphs are unknown.

Remarks. See Muchmore (1968) for a detailed description of C. oregonicus.

Kleptochthonius Chamberlin 1949

Two species of this genus have been reported from Oregon, $\underline{K}$. geophilus and $\underline{K}$. oregonus (Malcolm \& Chamberlin 1961). Since most Oregon specimens appear to be intermediates between the two species, further study may reveal that $\underline{K}$. geophilus is a junior synonym of $\underline{\text { K}}$ oregonus. Data are given under $\underline{\mathrm{K}}$ - oregonus as it has page priority. See Malcolm and Chamberlin (1961) and Muchmore (1974a) for descriptive data concerning the genus.

Kleptochthonius (Kleptochthonlus) geophilus Malcolm \& Chamberl in 1961 Geographical distribution. Oregon (Map 9). This species is known from only one locality at an elevation near $0 \mathrm{~m}$ in Curry County, Oregon (Malcolm \& Chamberlin 1961). It was not collected in my samples.

Habitat. Leaf 1 itter of red alder.

Seasonal distribution. Oregon adults and nymphs were collected in Apri1. 


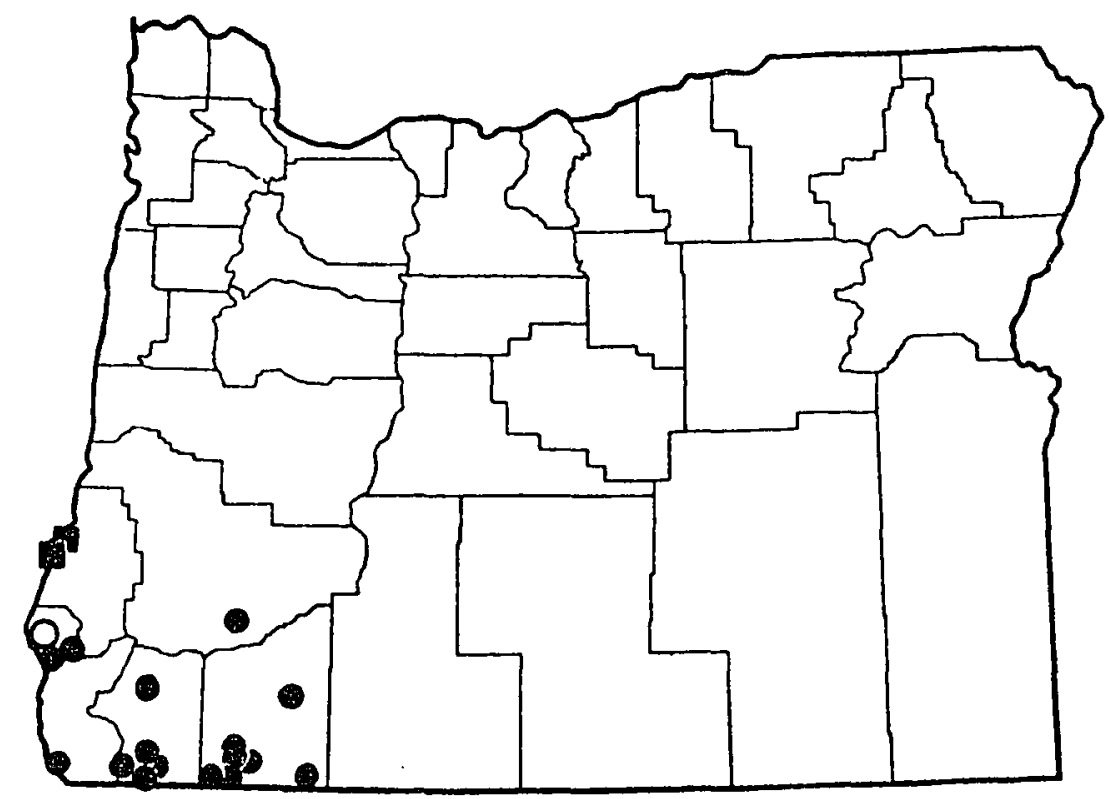

Map 9. Nistribution in nregon: Chthonius oregonicus , Kleptochthonius geophilus $\mathrm{O}$, K. oregonus -

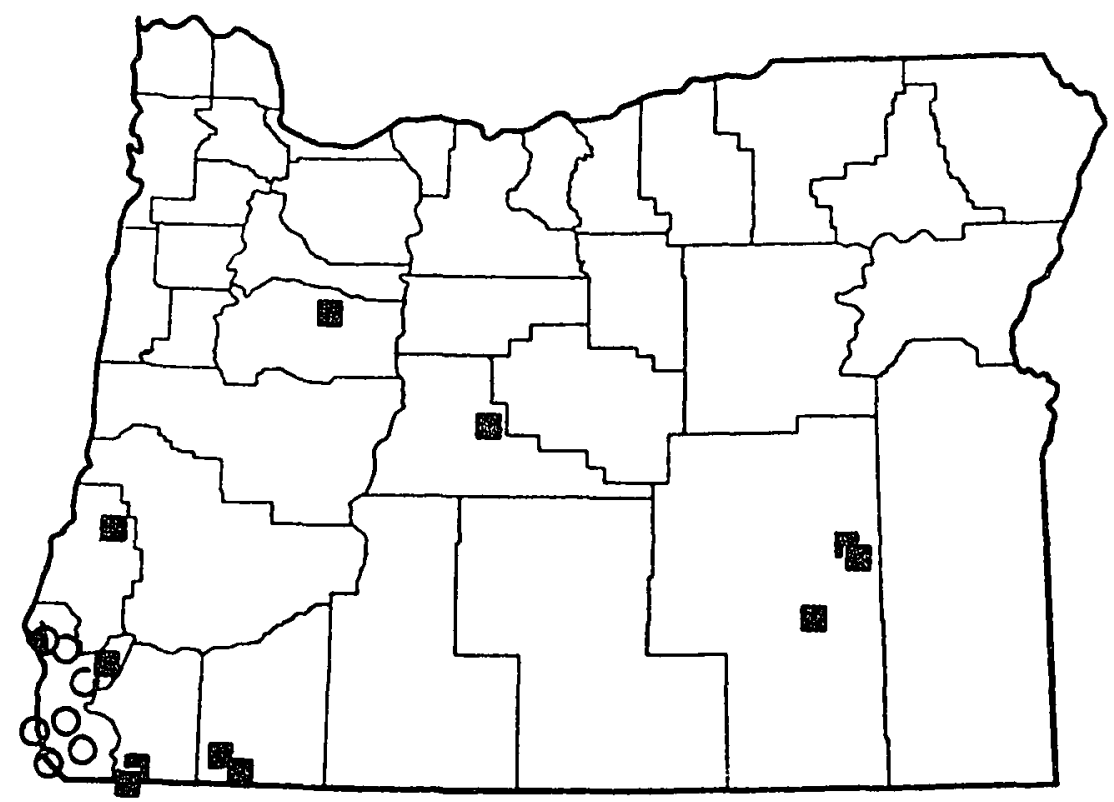

Map 10. Distribution in Oregon: Lechytia hoffi , Malcolmochthorius malcolmi 0 , M. orejunus 0. 
Remarks. This species may be a junior synonym of $\underline{k}$. oregonus.

Kleptochthonius (Kleptochthonius) oregonus Malcolm \& Chamberlin 1961

Geographical distribution. Oregon (Map 9). This species was reported previously from one locality in Josephine County, Oregon (Malcolm \& Chamberlin 1961). Now it is known from more than 50 samples from southwestern Oregon taken at elevations from $120-1525 \mathrm{~m}$ in the Western Hemlock, Mixed Conifer and Mixed Evergreen Zones of the Siskiyou Mountains and western Cascade Mountains.

Habltats. Leaf litter. $\underline{k}$ oregonus was collewed with about an equal frequency from sclerophyllous litter of madrone, tan oak, canyon 1 ive oak, chinkapin (Castanopsis chrysophylla (Dougl.) A. DC.) and manzanita; deciduous litter of bigleaf maple, Oregon white oak and Callfornla black oak; and coniferous litter of Douglas-fir, white fir (Abies concolor (Gord. \& Glend.) Lindl.), incense cedar, ponderosa pine and sugar pine. It also occurred in a sample of moss from a bigleaf maple tree, from bark of a willow tree ( Salix $\left.\mathrm{sp}_{.}\right)$, from wood of a rotted stump and from wood of a Douglas-fir log.

Seasonal distribution. Oregon adults were recovered from September through February and in April. Nymphs were not sorted separately.

Remarks. Although Malcolm and Chamberlin (1961) provided excellent descriptions of $\underline{K}$. geophlius and $\underline{K}$ - oregonus, a redescription is needed in view of recent findings. See remarks under $\underline{k}$ geophilus.

\section{Lechytia Balzan 1891}

One species, Lechytia hoffi Muchmore, has been reported from Oregon (Muchmore 1975). Although only recently described by Nuchmore 
$(1975 a), \underline{L}$ hoffi has a long, confused history under the name of "Lechytla paciflca (Banks)." The first specimens of the taxon were reported from Mt. Hamilton, California (Chamberlin 1925) and misidentifled as Roncus pacificus Banks (1893). Chamberlin, at the same time, transferred $\underline{R}$. pacificus to Lechytia; hence subsequent records and references concerning $\underline{L}$. hoffi up to 1968 are under $\underline{L}$. pacifica (Chamberlin 1929a, 1931; Beier 1932a; Hoff 1952, 1956a, 1958, 1961, 1963; Hoff \& Clawson 1952). In 1968, Schuster reported that Banks' type spectmens of Roncus pacificus belonged to the genus Mundochthonius Chamberlin, instead of Lechytia. This left the western North American species of Lechytia without a specific name. Muchmore (1975a), therefore, named the taxon Lechytia hoffi and described it from large series of specimens.

\section{Lechytia hoffi Nuchmore 1975}

Geograpilical distribution. Arizona, California, Colorado, Nevada, New Mexico, Oregon (Map 10), South Dakota, Utah and Washington. Muchmore (1975a) reported $\underline{L}$. hoffi from localities in nine states including one in Harney County, Oregon (Benedict Collection). Oregon specimens were recovered from at least 25 samples collected at elevations from 150-1525 m east and west of the Cascade Mountains.

Habitats. Leaf litter, bark, rotted wood. In New Mexico and Colorado, L. hoffi appears adapted to living in relatively dry litter of juniper, pinyons and ponderosa pine (Hoff 1961). Oregon specimens are from samples of material from ponderosa pine, western juniper (Juniperus occidentalis Hooke $=$ ) : Douglas-fir, madrone, manzanita, Oregon white oak and red alder. L. hoffi occurred in bark samples 
from stumps, logs and living trees, rotted wood of stumps and snags, tree hollows, and in litter of roody plants. ‥ hoffi was also recovered from debris of harvester ant nests.

Seasonal distribution. Oregon adults were collected in May, June, July, September and November; nymphs were not sorted separately. Remarks. See Muchmore (1975a) for a modern-style description of L. hoffi.

\section{Malcolmochthonius Benedict 1978}

Two species of this genus are reported from Oregon (Benedict 1978a). See Benedict (1978a) for a detailed description of the genus.

\section{Malcolmochthonius malcolmi Bened ict 1978}

Geographical distribution. California, Oregon (Map 10). This species is known from Humboldt County, California, and Curry County, Oregon (Benedict 1978a). Oregon specimens were collected from seven localities at elevations from $0-900 \mathrm{~m}$ in the Sitka Spruce, hestern Hemlock and Mixed Evergreen Lones of the western Siskiyou Mountains.

Habitats. Leaf litter. The California specimen was collected from the 1 itter of coast redwood (Sequola sempervirens (D. Don) End1.). Oregon specimens came from litter of Sitka spruce, sugar pine, knobcone pine (Pinus attenuata Lemm.), Douglas-fir, tan oak, madrone and manzanita.

Seasonal distribution. Oregon adults were collected in February, March, May and August; nymphs are unknown.

Remarks. See Benedict (1978a) for a detailed description of M. malcolmi. 
Malcolmochthonius oregonus Benedict 1978

Geographical distribution. Oregon (Map 10). This species is

known from one locality at an elevation of $250 \mathrm{~m}$ in the Mixed Evergreen Zone of Curry County.

Habitats. Leaf litter of mixed Douglas-fir and tan oak.

Seasonal distribution. An Oregon adult was collected in May; nymphs are unknown.

Remarks. See Benedict (1978a) for a detailed description of M. oregonus.

Mundochthonius Chamber1in 1929

This genus has not been reported previously from Oregon except as "Mundochthonius" from specimens in the same collections with Pseudotyrannochthonius incognitus (Benedict \& Malcolm 1970). Individuals of Mondochthonius are nearly as common in the leaf litter habitats of western Oregon as those of Apochthonius. The dearth of Oregon records results from several factors. There is, and has been a paucity of chelonethologists studying western North American chthoniids. Three of the four described western species, M. erosidens Chamberlin (1929a), M. magnus Chamberlin (1929a) and M. pacificus (Banks) (1893) lack adequate descriptions, and were reported previously only from type series. Even N. montanus Chamberlin (1929a), reported from a number of Colorado and New Mexico specimens (Chamberlin 1929a; Hoff 1956a, 1961), is still incompletely described. The misdetermination of M. pacteicus has caused considerable confusion (see discussion under Lechytia). My study of the type specimens of most described species of the 
genus (Benedict \& Malcolm 1973) and of hundreds of specimens from western North American localities, reveals that there are four to six species from Oregon. Three can now be identified by names M. magnus, M. erosidens and M. pacificus. The other "species", while common, cannot be characterized at this time and are not discussed further in this work.

Mundochthonius erosidens Chamberlin 1929

Geographical distribution. California, Oregon (Map 11). This species has been reported previously from one specimen collected in 1923 from San Mateo County, California (Chamberlin 1929a). It is now known from 16 collections taken at elevations from $60-2285 \mathrm{~m} \mathrm{in}$ western Oregon.

Habitats. Leaf litter, rotted wood. The California specimen was collected from under a rock of a damp serpentine outcrop. From Oregon, ‥ erosidens was collected from 1 itter of snowbrush ceanothus (Ceanothus velutinus Dougl. ex Hook.), western hemlock, Douglas-fir, western red cedar, bigleaf maple, California laurel and green manzanita. It also occurred in tree hollows of red alder, California laurel and Shasta fir (Abies magnifica Murr.), in rotted wood of a stump, and in a California laurel snag.

Seasonal distribution. Oregon adults were collected in August through October, and in February and May. Nymphs were not separated from adults.

Remarks. Although $M$ - erosidens is the type species of Mundochthonius, it has not been redescribed since Chamberlin's exceedingly brief description of 1929. 


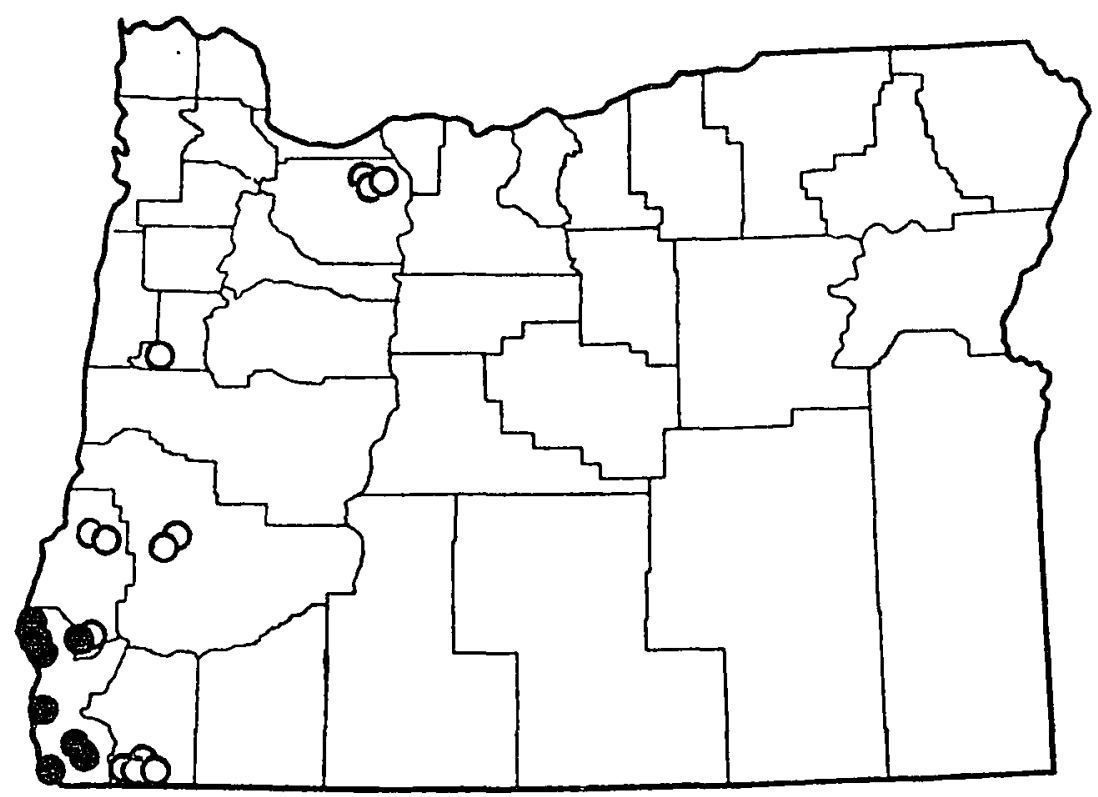

Map 11. Distribution in Cregons Mundochthonius erosidens 0 , M. magnus .

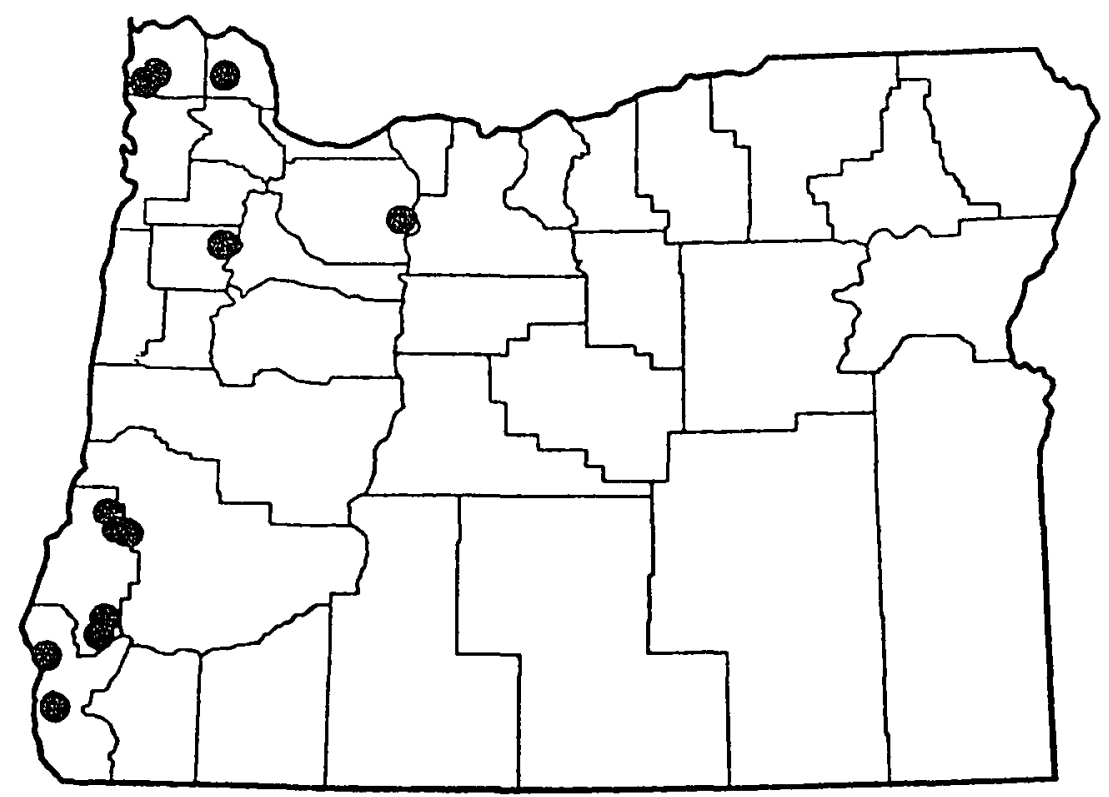

Map 12. Iistribution in Oregon: Munclochthonius pacificus 
Mundochthonius magnus Chamberlin 1929

Geographical distribution. Californla, Oregon (Map 11). This species has been reported previously from one specimen collected in San Mateo County, California (Chamberlin 1929a). It is now known from 13 collections taken at elevations from $0-1220 \mathrm{~m}$ in Coos and Curry Counties, Oregon, in the kiestern Hemlock and Mixed Evergreen Zones.

Habitats. Leaf litter. Habitat data for the California specimen are lacking. Oregon specimens came from 11tter of canyon 1 ive oak, tan oak, bigleaf maple, red alder, Douglas-fir and western white pine.

Seasonal distribution. Oregon adults were collected from February through May and in August and September. Nymphs were not recorded separately.

Remarks. This species has not been redescribed since the original very brief description of 1929.

Mondochthonius pacificus (Banks) 1893

Geogrdgical distribution. California, Idaho, Oregon (Map 12), llashington. Records of $\underline{M}$. pacificus and $\underline{L}$. hoffi were confused for approximately 40 years; prior to 1968 all records except those from Washington pertained to the genus Lechytia. Schuster (1968) redescribed "pacificus" from Banks' (1893) types and recognized it as a species of Mondochthonius. Schuster also mentioned specimens of M. pacificus from California and Idaho but did not give locality or habitat data. Oregon specimens of $M$. Dacificus are known from 15 collections taken at elevations from $0-1000 \mathrm{~m}$, mostly in the Interior Valley and hestern Hemlock Zones. 
Habitats. Leaf 1itter, moss, bark. Washington specimens (Malcolm Collection, unpub1. records) were recovered from samples of Douglas-fir litter. Oregon specimens occurred in samples of litter (Douglas-fir, California laurel), bark of living trees (Sitka spruce) and snags (red alder), tree hollows (tan oak, red alder), moss on tree trunks and branches, and debris of a shrew's nest.

Seasonal distribution. Oregon adults were collected from February through August and in November. Nymphs were not recorded separately.

Remarks. Although Schuster (1968) redescribed this species from the type series, a redescription is needed based on a large series of specimens reflecting intraspecific variation.

Neochthonius Chamberlin 1929

One species of this genus is now being reported from Oregon. See Muchmore (1969a) for a brief discussion of this genus.

Neochthonius amplus (Schuster) 1962

Geographical distribution. California, Oregon (Map 13). This species has been reported previously from Yolo County, California (Schuster 1962). It is nor known from 12 collections taken at elevations from $0-450 \mathrm{~m}$ in the Interior Valley Zones of Curry, Josephine, Jackson, Douglas, Yamhill and Washington Counties, Oregon.

Habitats. Leaf 11tter. California specimens came from soll, leaf litter and decomposing wood beneath elderberry (Sambucus sp.) and valley oak (Quercus lobata Nee). Oregon specimens were recovered from litter samples taken beneath Oregon oak, California black oak, canyon live oak, bigleaf maple, manzanita, madrone, and Douglas-fir. These habitats 
occur in drier forests of western Oregon.

Seasonal distribution. Oregon adults have been recovered in January, March, Apri1, August and October. Nymphs are unknown.

Remarks. A detailed description is needed for this species. It was originally described under the name of kewochthonius amplus, then Muchmore (1969a) transferred it to the genus Neochthonius.

\section{Pseudotyrannochthonius Beier 1932}

Two species, $\underline{P}$. gracilis and $\underline{P}$. incognitus, occur in Oregon. See Benedict ani Malcolm (1970) for a detailed study of the genus in the Pacific Northwest. $\underline{P}$. newelli was recognized as a junior synonym of P. Incognitus.

Pseudotyrannochthonius gracilis Benedict \& Malcolm 1970

Geographical distribution. California, Oregon (Map 14), Washington. Reported previously from southwestern Washington and northwestern California (Benedict \& Malcolm 1970), P. graclis has now been collected from two localities in southwestern Oregon near the Callfornia border at elevations of $450 \mathrm{~m}$ (Jackson County) and $1220 \mathrm{~m}$ (Josephine County).

Habltat. Leaf litter and debris. Benedict and Malcolm $(1970,50)$ considered this species to be associated with "either moss or coniferous duff rather than deciduous debris." One of the two Oregon specimens came from Douglas-fir litter and the other one from "the lower crawlway in total darkness" in Oregon Cave (Benedict Collection, unpubl, record). Seasonal distribution. Oregon adults of $\underline{p}$. gracilis have been collected from November through February. Nymphs are unknown. Remarks. See Benedict and Malcolm (1970) for a detailed 


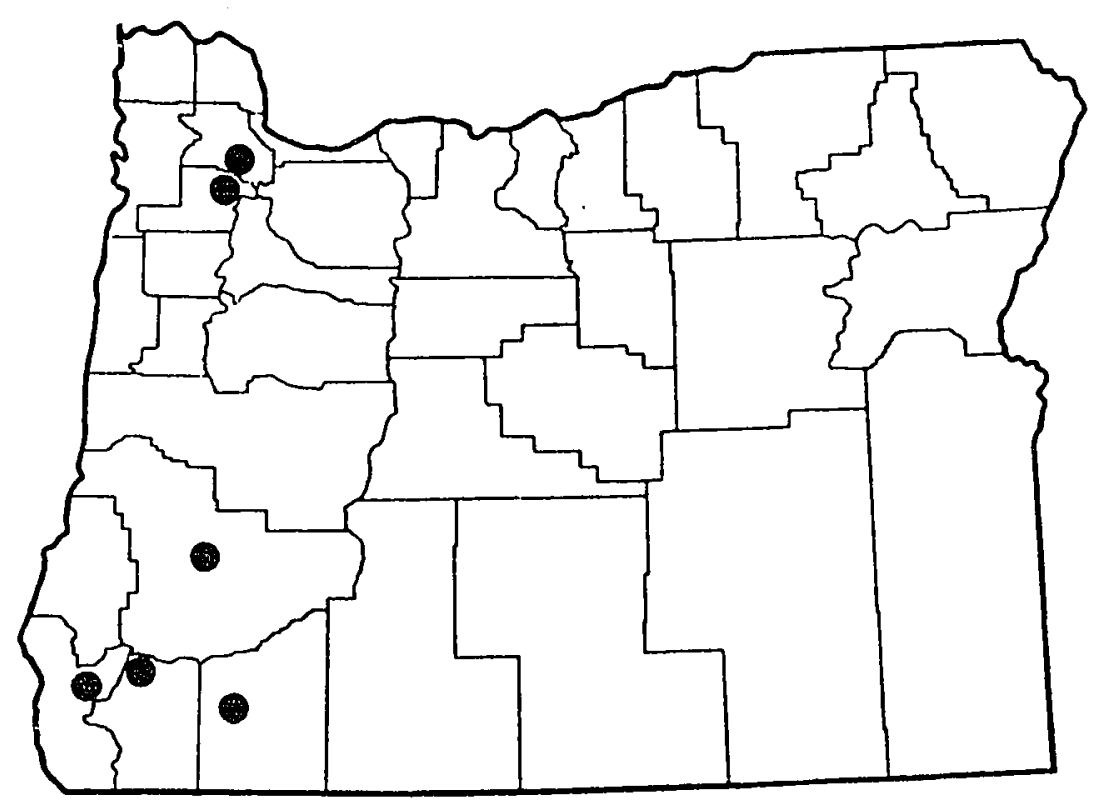

linp 13. Distribution in Oregon: Neochthonius amplus

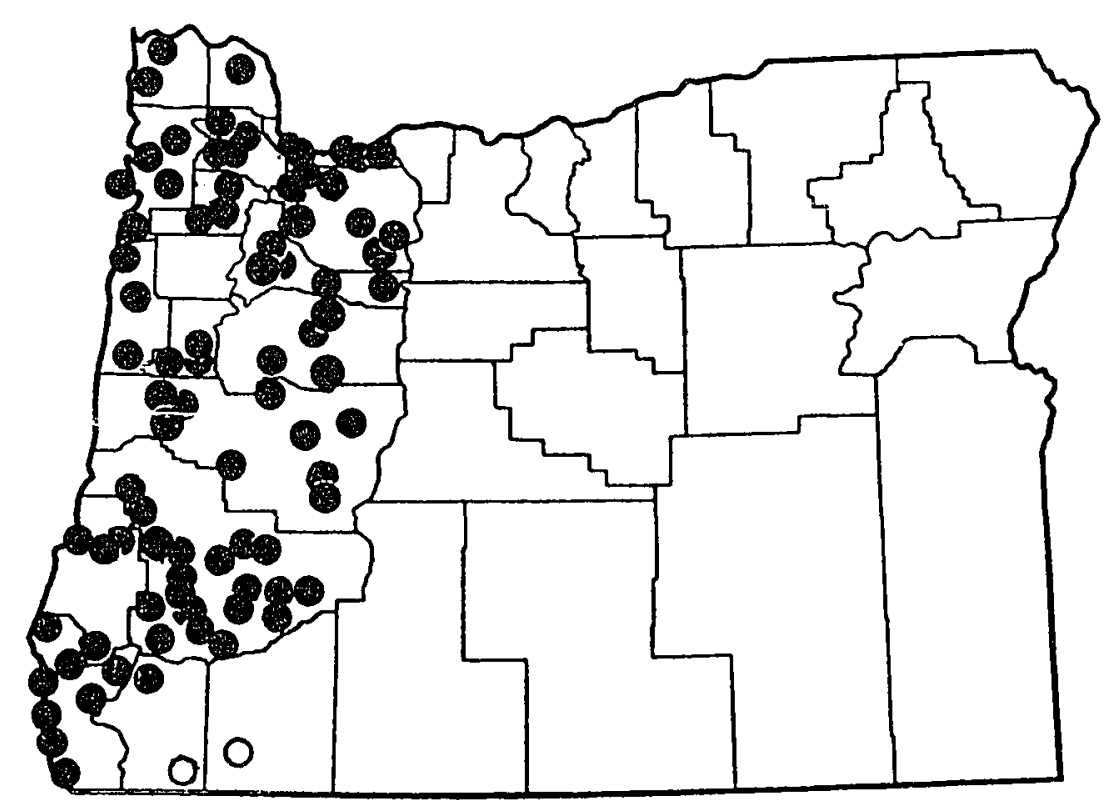

Man 14. Sistrijution in Oregon: Pseudiotyrannochthonius pracilis $\mathrm{O}, \mathrm{p}$. incornitus $\mathrm{P}$ 
description of this species. The Oregon specimens are clearly conspecific with those from Washington and California but are silghtly larger (see measurements in Appendix IV).

Pseudotyrannochthonius incognitus (Schuster) 1966

Geographical distribution. California, Idaho, Oregon (Map 14), Washington. Aslde from a single collection from Shoshone County, Idaho (Schuster 1966a), P. incognitus is known from localities west of the Cascade Mountains between Skamania County, Washington, and Humboldt Cuunty, California. It is currently known from over 160 collections taken at elevations from $0-1220 \mathrm{~m}$ in the Western Hemlock, Sitka Spruce, Interfor Valley and Mixed Evergreen Zones.

Habitats. Leaf litter, soil and decaying rood. Benedict and

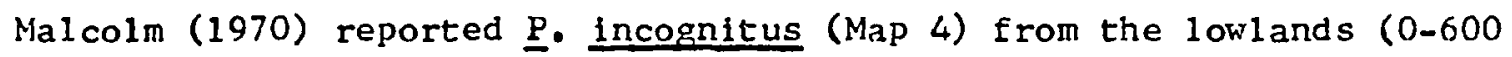
m) Erom samples of leaf litter, soll and decaying wood of bigleaf maple, vine maple, red alder, Oregon white oak, California black oak, Douglasfir, western hemlock, western red cedar and sitka spruce. In the present study, $\underline{p}$. incognitus occurred in more than 110 western Oregon samples from mosses and 1 ichens on the ground, rocks and tree trunks, deciduous-coniferous debris mixed with sclerophyllous litter of canyon live oak, California laurel, tan oak, madrone and manzanita, and in a sample of pure sugar pine litter from the Mixed Evergreen Lone of Curry County. P. Incognitus was not recovered in samples from the Rogue River portion of the Interior Valiey Zone or from eastern Oregon. Seasonal distribution. Oregon adults were collected during all months of the year, nymphs only from July through November. Protonymphs are unknown. 
Remarks. See Benedict and Malcolm (1970) for a detalled description of this species.

SUBORDER DIPLOSPHYRONIDA Chamberlin 1929

This suborder is represented in the United States by two superfamilies, Neobisioidea Chamberlin and Garypoidea Chamberlin. Species of both superfamilies occur in Oregon.

SUPERFAMILY NEOBISIOIDEA Chamberlin 1930

This superfamily is represented in the United States by three families, Neobisildae Chamberlin, Syarinidae Chamberlin and Ideoroncldae Chamberlin. The latter is unknown from Oregon. Approximately 12 species of Neobisildae and one or two species of Syarinidae occur in rregon. Complex systematic problems beyond the scope of this study prevent most of these species from being characterized at th 1 s time.

FAMILY NEOBISIINAE Chamberlin 1930

Neobisilds (Fig. 2) occur primarily in the Northern Hemisphere (Chamberlin 1931) and commonly inhabit leaf litter, soil, mosses and caves (Chamberlin \&: Malcolm 1960). In western Oregon, chthoniids and neobisilds generally occur in the same samples, with chthonilds present in greater numbers but neobisidis in greater biomass.

Prior to this study, five species had been reported from Oregon (Nap 5). Microcreagris theveneti (Simon) was reported in Banks (18958 11) "In moss and rotted wood, Portland and Astoria, Oregon(Hubbard); Portland, Nregon (Schwarz)" and as "common in the coast regions of Oregon" (Banks 1910:37). Parobislum hesperum (Chamberlin) is the second 


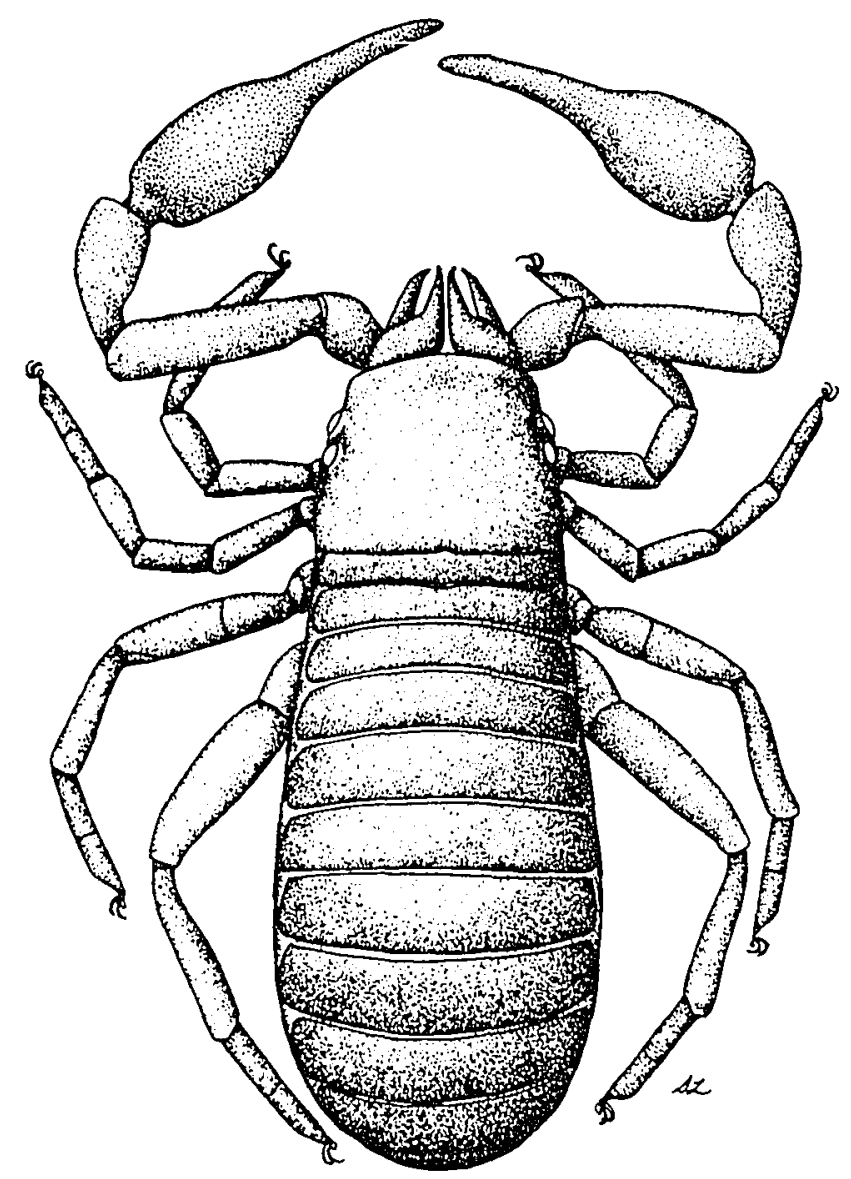

F1gure 20 Halobisium occidentale Beler, a neoblaild species of the high tidal zone. (Body length $3-4 \mathrm{zm}$ ). 
species of any family to have been described initially from an Orepon locality, i.e., from rubble beneath a $\log$ above high tide 1 ine at Cannon Beach, Clatsop County (Chamberlin 1930). Microcreagris cingara Chamberlin was reported from Springfield, Lane County, by Chamberlin in 1930. In 1962, Chamberlin described $\underline{p}$. charlotteae Chamberlin from Redmond Cave, Deschutes County, and $\underline{N}$. columbiana Chamberlin from a well at Clatskanie, Clatsop County. Even though neobisilds are fairly abundant in western Oregon and are well-represented in the samples, there are few criteria available for assigning most specimens to species, even the species mentioned above. Therefore, these species are not treated under separate species accounts.

There is, however, one very distinctive littoral species, Halobisium occidentale Beler, which can now be reported from Oregon. Halobisium Chamberlin 1930

This genus is currently under study by Shulte (1976, pers. comm.). One species is known to occur along the Oregon coastline.

Halobisium occidentale Beier 1931

Geographical distribution. Alaska, California, Oregon (Map 15), Vashington. This species was reported previously from Palo Alto, Callfornia (Beier 1931, 1932a). Now it is known from a number of coastal localities from California through Alaska (Chamberlin-MalcolmBenedict Collection, unpubl. records), where it occurs in the high tide zone (Shulte 1976).

Habitats. Tidal flats. Chamberlin (1930) collected more than 45 specimens near Palo Alto, California, from under boards and driftwood in Salicornia salt marshes which flood at high tide. H. occidentale is 


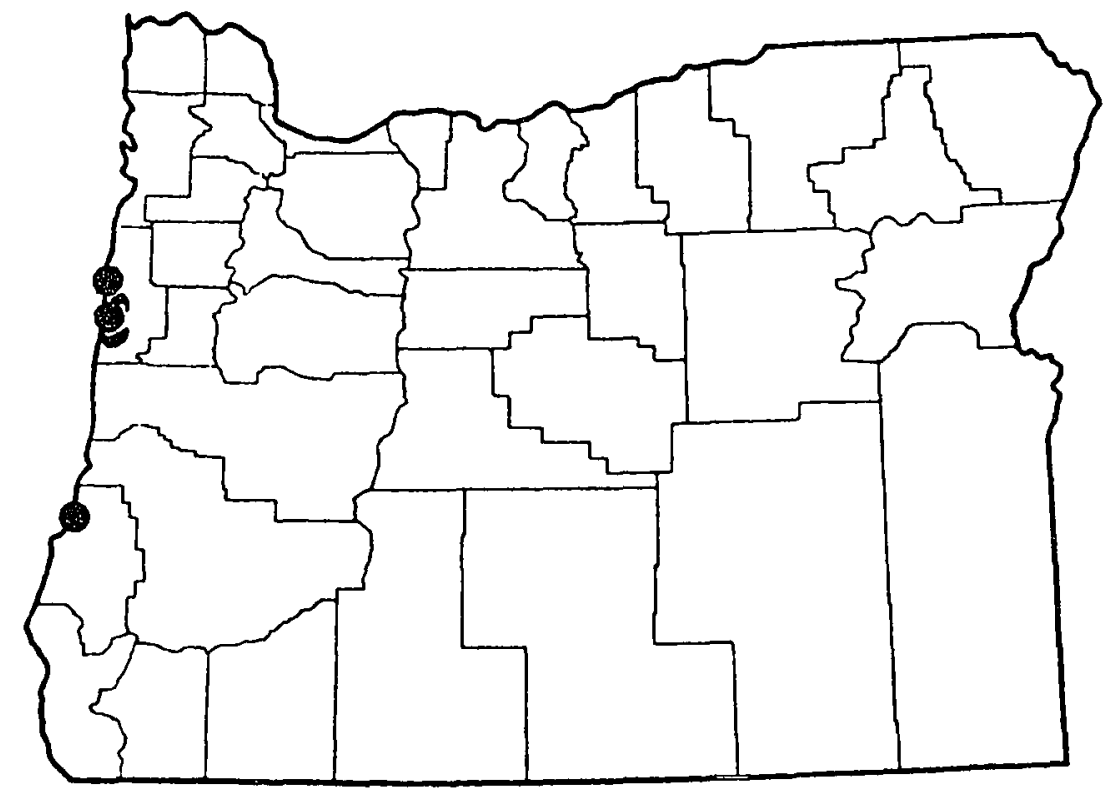

Map 15. Distribution in Oregon: Malobisium occidentale . 
known from six Oregon localities where it was collected under boards and debris of Salicornia-saltgrass tidal flats, in estuary-water soaked bark of a sitka spruce tree-root, in a log eaten by boring clams (Teredo sp.) in the high tide zone, and in a gribble burrow (Limnoria $\mathrm{sp}_{.}$) in wood from a slough (Benedict-Chamberlin-Malcolm Collection). Washingt on specimens (from Puget Sound area and Bay Center) did not include habitat data (Chamberlin Collection). From Alaska ("Glacier Bay, north side of Lagoon Island, $87 \mathrm{~km} 283^{\circ} \mathrm{fm}$ Juneau"), eight specimens were collected "under 50 rocks 5-10 m down from high tide, 14 IX 1977" (Burke Nuseum Collection).

Seasonal distribution. Oregon adults were collected in March, Apr1l, May, July and August; nymphs are unknown. Remarks. Shulte (pers. comm.) is redescribing this species.

FAIIILY SYARININAE Chamberlin 1930

This family is well represented in Oregon by the genus Syarinus Chamberlin (Fig. 3) but individual species have yet to be identified. Specimens of Syarinus were collected from leaf litter in montane areas of the Steens Mountain (Harney County) and the western Cascade Mountains (Lane County), and from the sinks of the Arnold Lavatube System (Deschutes County). Specimens were also collected from bark samples from humid coastal forests (Lincoln County). Oregon specimens appear to represent at least two species.

SUPERFAMILY GARYPOIDEA Chamberl in 1930

This superfamily is represented in the United States by three families, Garypidae Hansen, Olpiidae Chamberlin and Menthidae Chamberlin. 


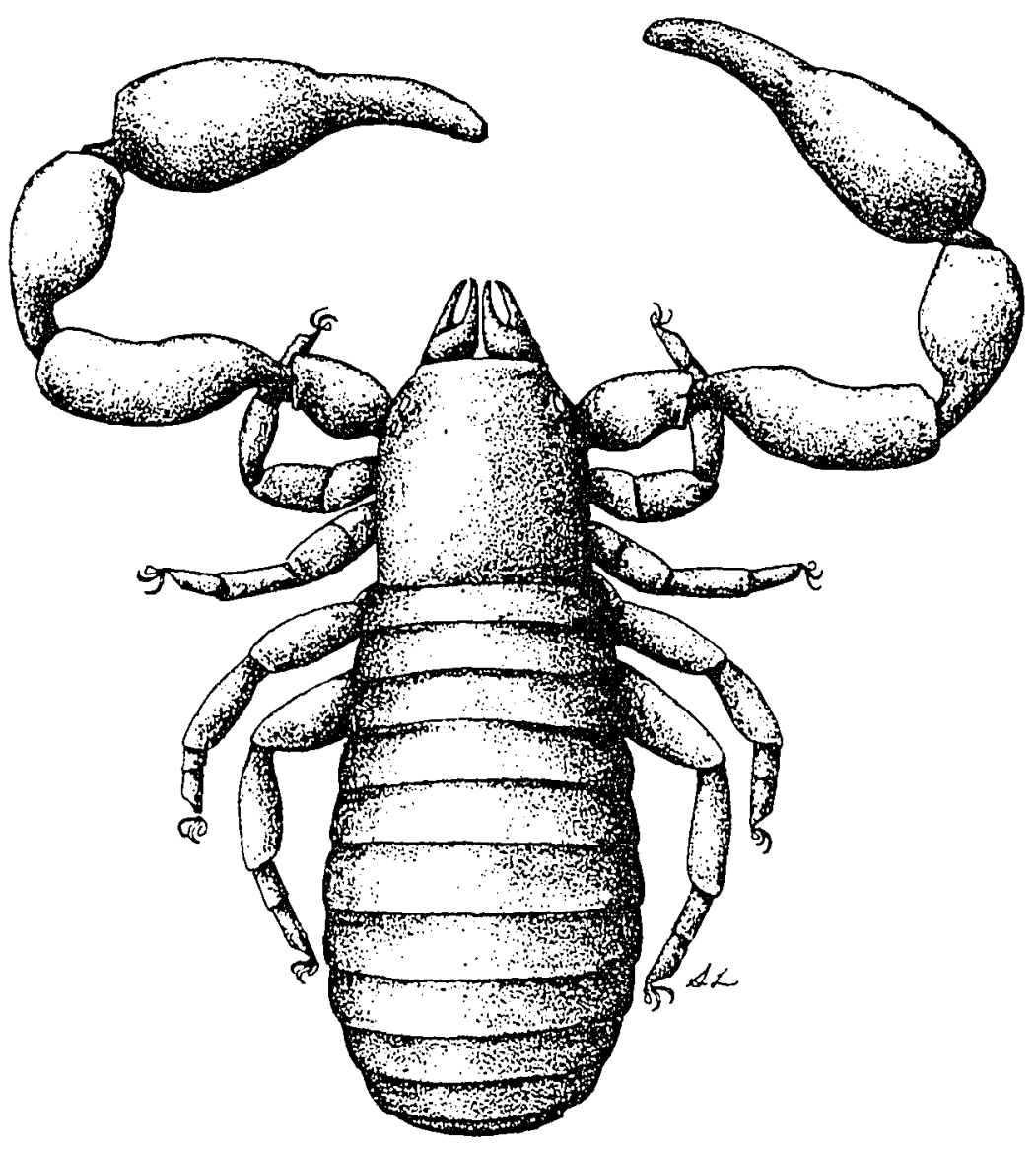

Figure 3. Syarinus sp., a leaf 1itter-inhabiting syarinid specles frow eastern Oregon. (Body length $2-3$ 
Of these, only garrypids and olpilis are reported from Oregon (Benedlct \& Malcolm I977).

FAMILY GARYPIDAE Hansen 1894

Garypids (Fig. 4), assigned to about 20 genera, are considered as mostly tropical and subtropical in distribution (Hoff 1964). Of the approximately six species known from the United States, Benedict and Malcolm (1977) recently reported the first records from Oregon of this family. Larca chamberilni Benedict and Malcolm was described from western Oregon and Archeolarca rotunda Hoff and Clawson was reported from eastern Oregon. In addition to these two species, a specimen of Larca notha Hoff is now reported from Harney County, Oregon.

\section{Archeolarca Hoff \& Clawson 1952}

One species of this genus is reported from Oregon (Benedict \& Malcolm 1977). See Hoff and Clawson (1952) for a detailed description of the genus.

Arctieolarca rotunda Hoff \& Clawson 1952 Geographical distribution. Oregon (Map 16), New Mexico, Utah. Habitats. Only 23 specimens of this species have been reported from its entire range, all from rodent debris. Twenty-two of the specimens came from nests of pack rats (Neotoma cinerea (Ord) and N. albigula Hartley) and porcupine (Erethizon dorsatum epixanthum Brandt) In Utah (Hoff \& Clarson 1952) and in New Mexico (Hoff 1956b). One male was extracted from Neotoma (prob. N. cinerea) debris from Unnamed Cave, Arnold Lavatube System, Deschutes County, Oregon (Benedict \& Malcolm 1977). 


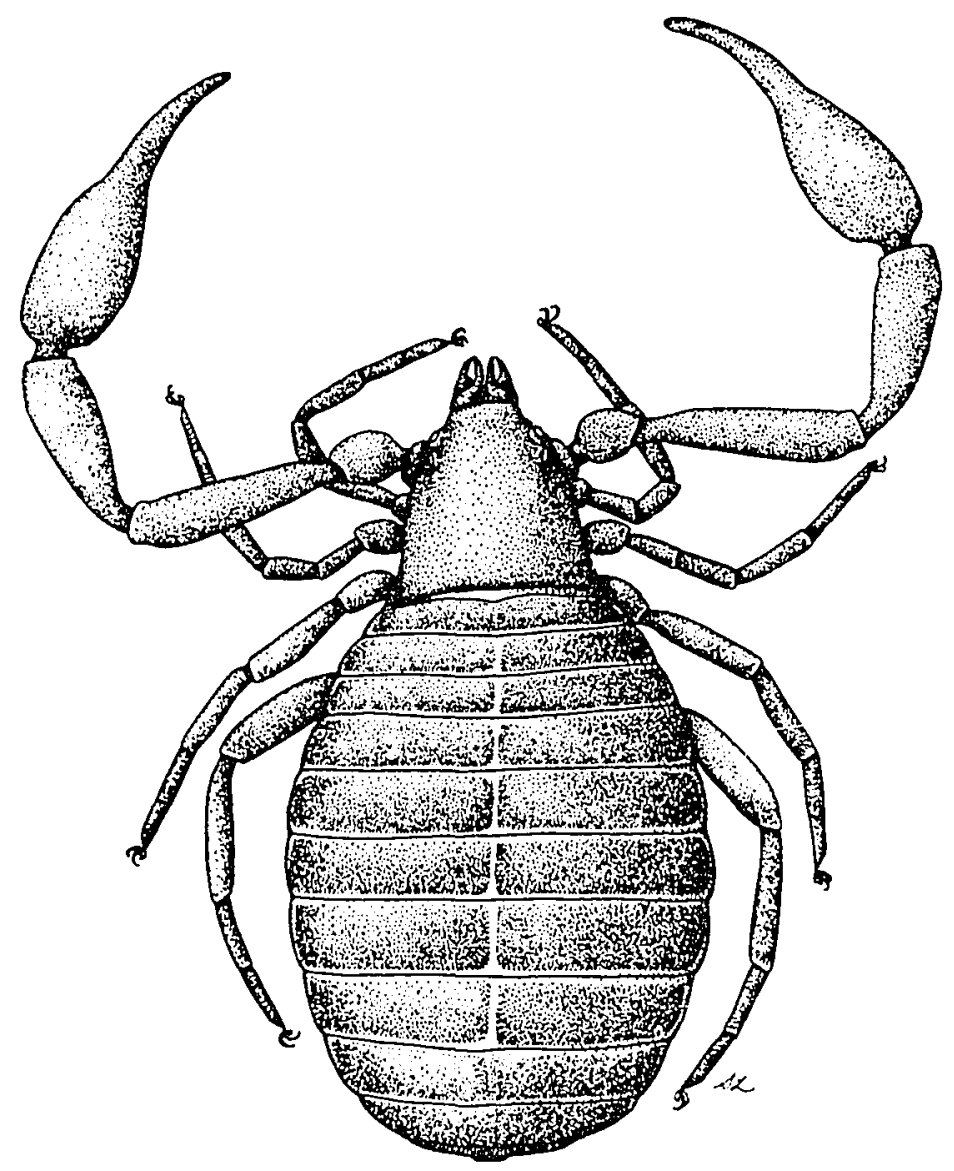

Flgure 4. Archeolarca rotunda Hoff \& Clawson, a garypid species frow animal nosts. (Body length $2.4-2.6 \mathrm{~mm}$ ). 


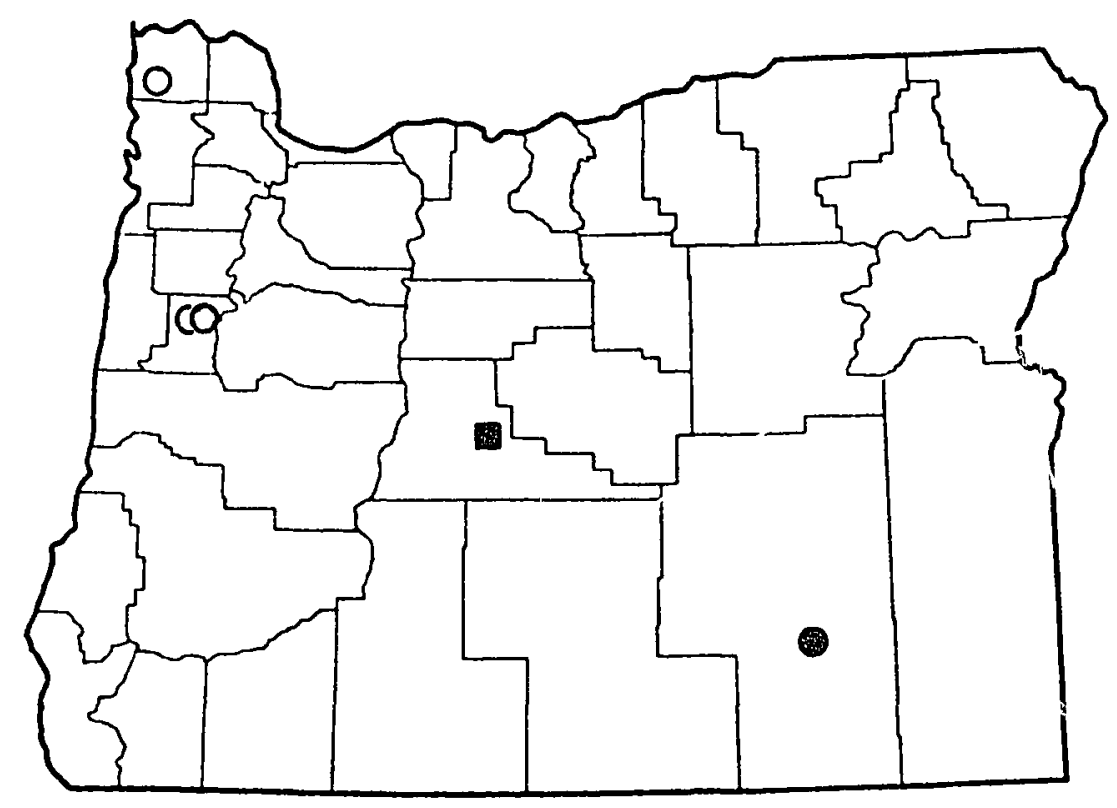

Map 16. Distribution in Oregon: Axcheolarca rotunda , Larca chamberlini $O$, L. notha 
Seasonal distribution. The Oregon specimen, a male, was collected in June. While nymphs are unknown for Oregon, they have been collected in Utah and New Wexico during October, November, February, March and Apr11.

Remarks. Although $\underline{A}$. rotunda was collected from a cave, it does not exhibit troglobitic tendencies; instead it is associated with rodents which inhabit the cave. Hoff \& Clawson (1952) provided a detalled description of this species.

\section{Larca Chamberlin 1930}

This genus is represented in Oregon by two species, $\underline{I}$. chamber$\underline{1 \text { ini }}$ and L. notha. See Benedict and Malcolm (1977) for a detailed study of the genus.

Larca chamberlini Benedict \& Malcolm 1977

Geographical distribution. California, Oregon (Map 15). This species was reported previously from four specimens from northern California and Benton County, Oregon (Benedict \& Malcolm 1977). Now it is known from two additional Oregon specimens, one from clatsop County and the other one from benton County. Oregon specimens have been collected at elevations near $0 \mathrm{~m}$ in the Sitka Spruce and Interior Valley zones.

Habitats. Mosses, old buildings. During the $1940^{\prime} \mathrm{s}$, four specimens were collected at four localities in Yuba County, California and Benton County, Oregon (Benedict \& Malcolm 1977). These specimens were elther phoretic on mosquitoes or associated with mosquitoes in old bulldings. In 1973, I recovered a nymph from mosses festooning a sitka spruce tree in Clatsop County, Oregon. 
Seasonal distribution. Oregon adults were collected in October and November, a nymph in July.

Remarks. See Benedict and Malcolm (1977) for a detailed description.

Larca notha Hoff 1961

Geographical distribution. Colorado, Oregon (Map 16). Known previously from Larimer County, Colorado (Hoff 1961), L. notha is now reported from Harney County, Oregon, where it was collected at an elevation of $1220 \mathrm{~m}$.

Habitats. Leaf litter. The Colorado specimen was collected from litter of quaking aspen (Populus tremuloides Michx.). The Oregon specimen was collected from debris caught between multiple trunks of mountain alder (Alnus incana (L.) Moench) growing in the riparian community along the Blitzen River at a site approximately $450 \mathrm{~m}$ lower in elevation than the nearest aspen grove on Steens Mountain.

Seasonal distribution. The Oregon adult was collected in Miarch. Remarks. See Hoff (1961) for a detailed description of $\underline{\text { L }}$ notha.

FAMIIY OLPIIDAE Chamberlin 1930

01piids (Fig. 5), with about 30 assigned species, appear to exhibit their greatest divergence in the arid tropics and subtropics (Chamberlin 1930). Fewer than 12 species are known from the United States and only two species have been reported from Oregon (Benedict \& Malcolm 1977): Oreolplum nymphum Benedict and Malcolm and Pseudogary= plnus Erontalis (Banks). 


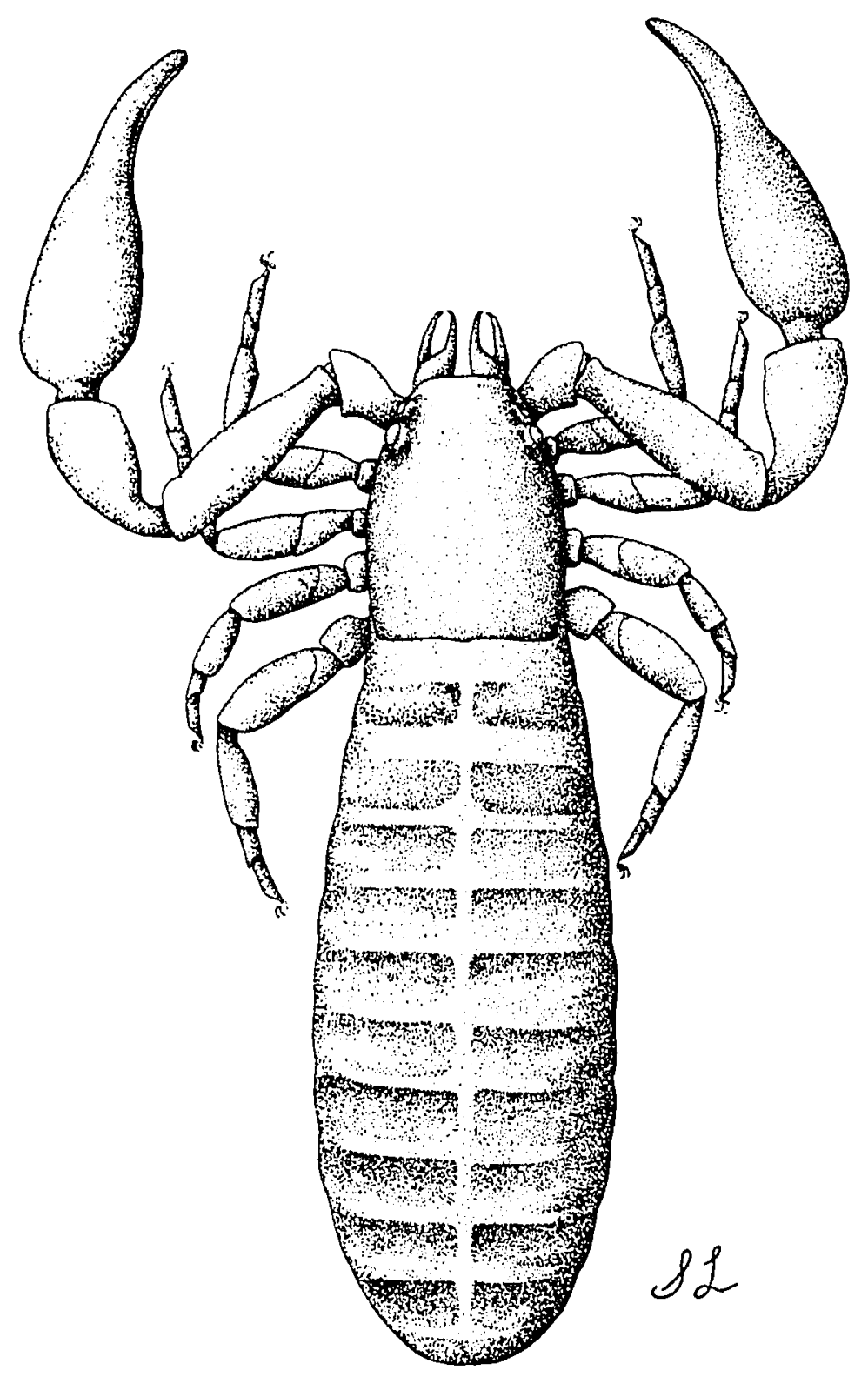

F1gure 5. Pseudogaryplnus Erontalis (Banks), a leaf litter and bark-inhtbiting olpild specles from southwestern Oregon. (Body length 3.0-4.6 m). 


\section{Oreolpium Benedict \& Malcolm 1977}

One species of this genus is reported from Oregon (Benedict \& Malcolm 1977). See Benedict and Malcolm (1977) for a detailed description of this genus.

\section{Oreolpium nymphum Benedict \& Halcolm 1977}

Geographical distribution. Oregon (Map 17). This specles is known only from widely scattered localities in western Oregon (Benedict \& Malcolm 1977). It occurs at elevations from 305-1675 $\mathrm{m}$ in the lestern Hemlock and Mixed Conifer Zones in the Cascade and Siskiyou 1 Mountains between Marion County and the California-Oregon border. Habitats. Bark. Ten collections came from samples of well-rotted bark of old-growth 0.6-2.5 $\mathrm{m}(\mathrm{dbh})$ conifers (Douglas-fir, western hemlock, sugar pine, ponderosa pine), but not from litter samples beneath these individual trecs. 0 . nymphum did occur in one sample of mixed Louglas-fir-myrtle-oak-maple litter collected at $150 \mathrm{~m}$ in a riparian community along the limpqua River.

Eeasonal distribution. Adults were collected in April, August, September and October. Nymphs were taken in September.

Remarks. See Benedict \& halcolm (1977) for a detalled description.

\section{Pseudogarypinus Beier 1931}

Cne species of this genus is reported from Oregon (Benedict \& Nalcolm 1977). See Benedict \& Malcolm (1977) for a detailed redescription of this genus. 


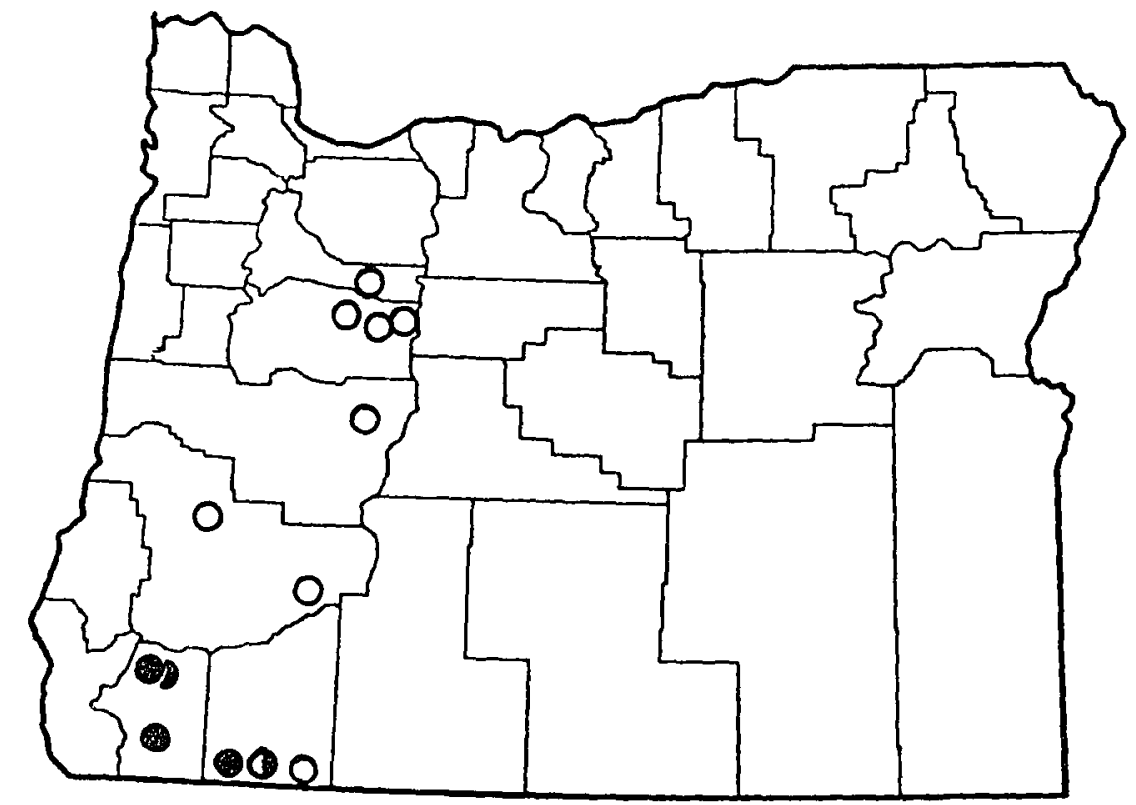

Map 17. Distribution in Oregon: Oreolpium nymphum 0 , Pseudogarypinus frontalis 
Pseudogarypinus frontalis (Banks) 1909

Geographical distribution. California, Colorado, New Mexico, Oregon (Map 18), Utah, Hashington. This species is distributed at widely scattered localities from the Rocky Mountains to within a few miles of the Pacific Ocean (Benedict \& Halcolm 1977). Oregon specimens were collected from Jackson and Josephine Counties at elevations from 150-1465 $\mathrm{m}$ in the Interior Valley and Mixed Conifer Lones of the Siskiyou Nountains.

Habitats. Leaf litter, bark. Benedict and Malcolm (1977) in their recent study compiled habitat data for all known collections of P. frontalis and reported it from leaf litter, wood of living and dead trees, stumps and logs, bark of living trees, and rock crevices. The 12 Oregon specimens were collected in four samples of leaf litter (sugar pine, Jeffrey pine, California black oak, canyon live oak) and in two samples of bark from living trees (Douglas-fir, madrone).

Seasonal distribution. Oregon adults were collected in April, August, September and November, nymphs in September. One female bore six eggs (April collection).

Remarks. See Benedict and Malcolm (1977) for a detailed redescription based on the restudy of syntypes and a large series of specimens from throughout its range. $\underline{p}$. marianae was also recognized as a junior synonym of $\underline{\text { P. Erontalis. }}$

SUBORDER MONOSPHYRONIDA Chamberl in 1929

This suborder is represented in the United States by three superfamilies, Feaelloidea Chamberlin, Chelridioldea Chamberlin and 
Cheliferioidea Chamberlin. All three occur in Oregon.

SUPERFANILY FEAELLOIDEA Chamber 1 in 1930

This superfamily is represented in the United States by one family, Pseudogarypidae Chamberlin. See Benedict and Malcolm (1978a) for a detalled study of Pseudogarypidae.

FAMILY PSEUDOGARYPIDAE Chamberlin 1930

The family Pseudogarypidae includes several fossil species from Europe, six extant species from North America (Fig, 6) and one extant species from Tasmania (Benedict \& Malcolm 1978a, Muchmore pers. comm.).

Pseudogarypus Ellingsen 1909

The first valid pseudogarypid records from Oregon were only recently reported (Benedict $\&$ Malcolm 1978a), despite Chamberlin's (1931:231) mention of "a hitherto undescribed form From Oregon." The species in question apparently is Pseudogarypus hesperus which Chamberlin (1931) diagnosed without reporting Oregon records. Nearly 50 years later, Benedict and Malcolm (1978a) provided the first records from Oregon for both $\underline{\underline{P}}$ hesperus and $\underline{\underline{P}}$. bicornis (Banks). The two species in Oregon are partially sympatric (Maps 17-18). In areas of overlap, P. bicornis occurs at lover elevations, especially in southwestern Oregon (see Table II). Benedict and Malcolm (1978a) provide a detailed redescription of this genus.

Pseudogarypus bicornis (Banks) 1895

Geographical distribution. Arizona, California, Colorado, Idaho, Oregon (Map 18), Utah, Washington, Wyoming. This species occurs from 


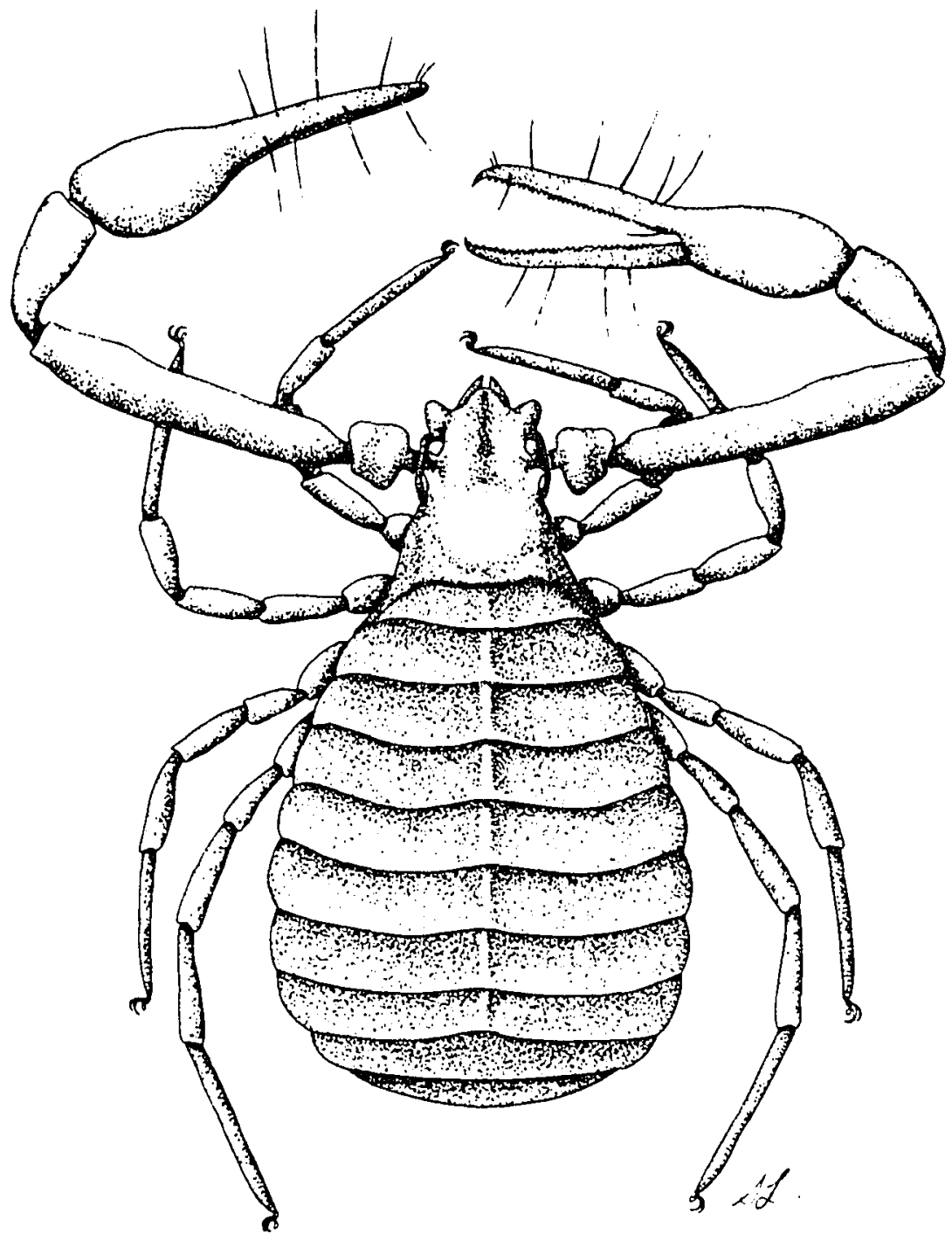

Flgure 6. Pseudogarypus bicornls (Banks), a leaf litter and bark-inhabiting pseudogarypid species from Oregon. (Body length 2.2-3.3 $\mathrm{mm}$ ). 


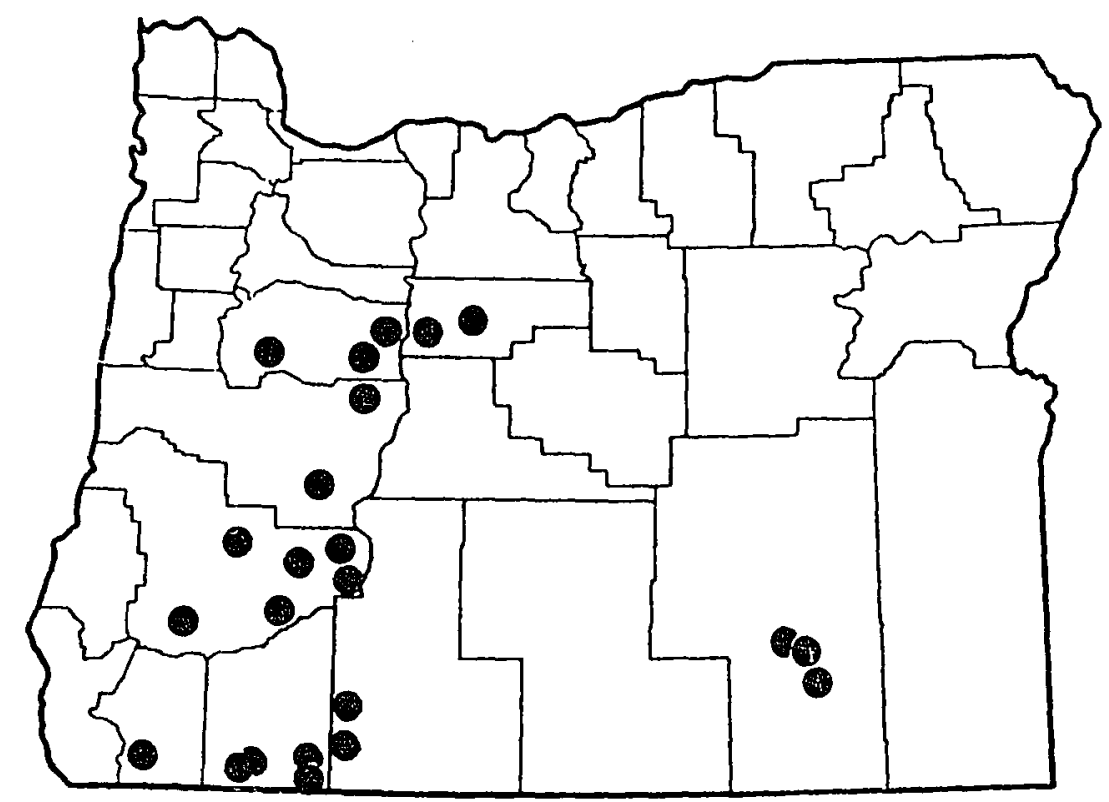

Map 12. Wistribution in Cregon: Pseudorarypus bicornis

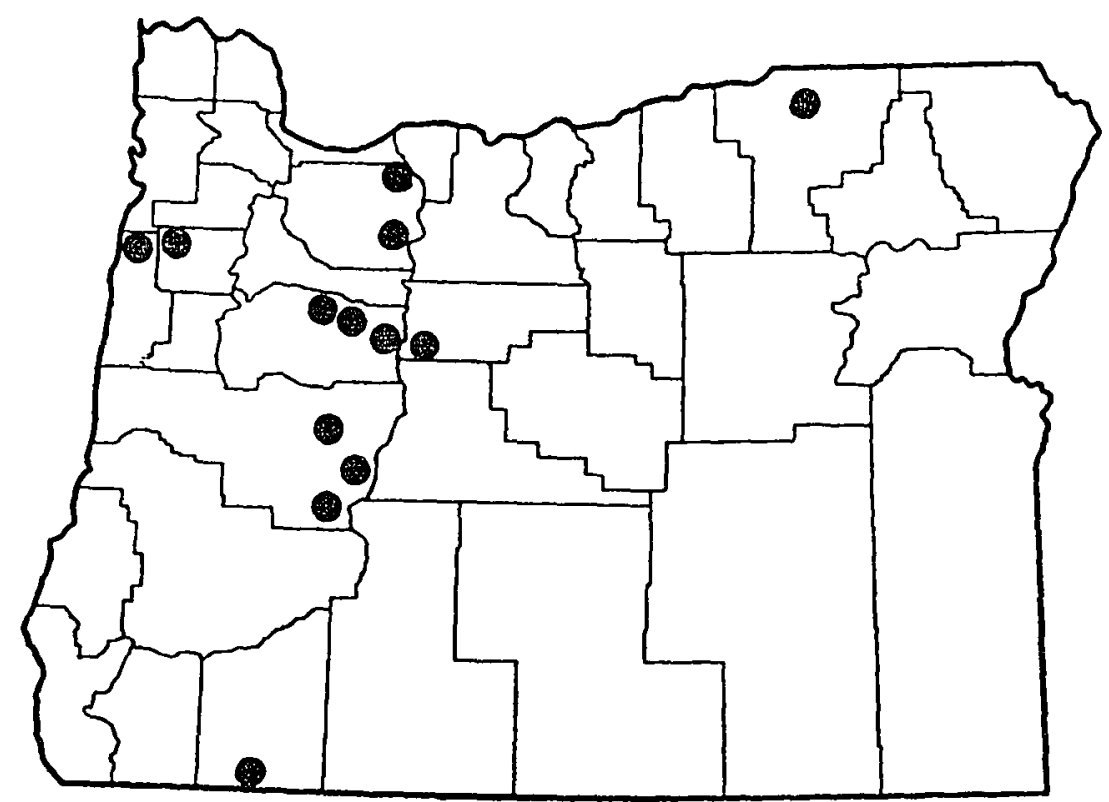

Mar 19. Mistrihution in Oreoons jescutogarypus hesperus $\circ$ 
the Rocky Mountains nearly to the Paclfic coast at elevations from 300-3050 m (Benedict \& Malcolm 1978a). Oregon specimens came from 28 localities in eight counties, where it occurred in eight vegetation zones at elevations from 305-2075 m (Table II).

Habitats. Leaf litter, bark, tree hollows, mosses, rock crevices. Although Benedict and Malcolm (1978a), reported $\underline{P} \cdot \underline{\text { bicornis from }}$ approximately 50 localities throughout its range, most specimens, except those from Oregon, lack habitat data. From other states, P. bicornis was recorded from rock crevices, bark of a cottonwood stump, 1itter beneath birch (Betula $\mathrm{sp}_{.}$) and maple trees, and from a swallow's nest.

Oregon specimens were collected from a total of 24 leaf litter samples of lodgepole pine, ponderosa pine, sugar pine, incense cedar, white-grand fir (Abies concolor-grandis), Douglas-fir, madrone, bigleaf maple, mountain alder, willow and sagebrush. The sagebrush (Artemisia tridentata Nutt.) sample, collected from one of the rarest habitats in western Oregon, also came from the highest elevation $(2075 \mathrm{~m})$ at which

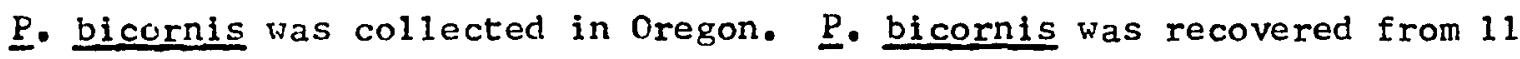
samples of material from living treest six bark samples from Douglas-fir, grand fir (Abies grandis (Dougl.) Lindl.), ponderosa pine, sugar pine, western yew ( axus brevifolia Nutto) and Engelmann spruce (Picea engelmannil Parry ex Enge $1 \mathrm{~m}_{\bullet}$ ); four tree hollow samples from Douglas-fir, grand fir, madrone and ponderosa pine; and one sample of moss-festoons from bigleaf maple. P. bicornis occurred in four samples of mosseslichens growing on rocks, and was hand-collected from under a rock. In harney County, it was collected exclusively from debris caught between multiple trunks of mountain alder and willows growing in riparian 
TABLE II

COMPARISON OP ELEVATIONS AND VEGETATION ZONES IN OREGON OF THO SPECIES OF PSEUDOGARYPUS ELLINGSEN

\begin{tabular}{|c|c|c|}
\hline \multicolumn{3}{|c|}{ WESTERN OREGON } \\
\hline & P. bleomis & P. hesperus \\
\hline Coast Range Mts. & & $620 \mathrm{~m}$ \\
\hline (Llncoln, Polk Co.) & & Hostern Hemlock Zone \\
\hline Northern Cascade Mts. & & $1000 \ldots 1070 \mathrm{~m}$ \\
\hline (Clackamas $\mathrm{CO}_{\bullet}$ ) & & Western Henlock Lone \\
\hline MIddle Cascade MEs. & $365-1280 m$ & $580-1525$ m \\
\hline (Linn, Lane, Jefferson Co.) & Mestern Hemlock Zono & $\begin{array}{l}\text { Hestern Hemlock Zone } \\
\text { Paclfle SIIver Fir Lone }\end{array}$ \\
\hline Southern Cascade Mts. & $305-1770 m$ & \\
\hline \multirow[t]{3}{*}{ (Douglas, Jackson Co.) } & Mixed Conlfer Zone & \\
\hline & White Flr Zone & \\
\hline & Shasta Red FIr Zone & \\
\hline Eastern Siskiyou MtB. & $915+-02075$ m & $2075 \ldots 2290$ m \\
\hline \multirow{3}{*}{ (Josephine, Jackson Co.) } & Mixed Conlfer Zane & Mountaln Henlock Zone \\
\hline & White Fir Zone & \\
\hline & EASTERN OREGON & \\
\hline Ochoco Mts. & $1525=$ & \\
\hline (Jufferson Co.) & Grand Fir Zono & \\
\hline Blue Mts. & & $1540=$ \\
\hline (Unat1Lla Co.) & & White Fir Zone \\
\hline Steen Mt. & $1280-1675=$ & \\
\hline (Hernoy $\mathrm{Co}_{0}$ ) & Hestern Junipor Zono & \\
\hline
\end{tabular}


communities of the Blitzen River drainage. Otherwise $\underline{P}$. bicornis appears to exhibit little habitat specificity except for non-coastal areas.

Seasonal distribution. The 39 Oregon collections were taken during every season of the year, often with both adults and nymphs of every stage. Eanks (1895) noted that the type collection from Yellowstone Park contained many nymphs in molting cocoons of silk and earth.

Remarks. See Benedict and ialcolm (1978a) for a detailed redescription based on large series of specimens from throughout its range.

Pseudogarypus hesperus Chamberl in 1931

Geographical distribution. Oregon (Nap 19), ::ashington. Known only from the Pacific Northwest (Chamberlin 1931; Benedict \& Malcoln: 1978a), P. hesperus is reported from four vegetation zones at elevations Eron near $0 \mathrm{~m}$ (southwestern Washington) to $1525 \mathrm{~m}$ (summit of Nit. Ashlancl). Habitats. Twenty of the 23 collections of $\underline{p}$. hesperus, including. the only one from hashington, came from well-rotted bark of $0.6-2.5 \mathrm{~m}$ (dbh) old-growth Douglas-fir, mountain hemlock (Isuga mertensiana (joug1.) Forbes) and western red cedar. A litter sample was taken under each of these trees (in Oregon), but $\underline{\underline{P}}$. hesperus was not recovered. Cne specimen came from beneath a rock and one specimen from an outhouse in $\exists$ forest camp.

Seasonal distribution. Oregon collections contained bnth adul:is and nymphs of every stage; collections were made in Apri1, Hay, Junc, Alrgust and September.

Remarks. See نenedict and Malcolm (1978a) for a detailed 
description of this species.

SUPERFAMILY CHEIRIDIOIDEA Chamber1In 1931

This superfamily is represented in the United States by two families, Chelridildae Chamberlin and Sternophoridae Chamberlin. Only specles of the Chelridildae have been reported from Oregon (Benedict 1977).

FAMILY CHEIRIDIDAE Chamberlin 1931

Cheiridilds (Fig. 7), assigned to about 12 genera, occur in every zoogeographical region except Australasia (Chamberlin 1931). Of approximately 12 species known from the United States, five were recently reported from Oregon (Benedict 1977). Apocheiridium bulbifenorum Benedict, A. fergusoni Benedict and A. granochelum Benedict were described with Oregon type localities, while A. ferumoides Chamberlin and A. mormon Chamberlin were reported for the first time from Oregon.

Apocheiridium Chamberlin 1924

Five species of this genus are known to occur in Oregon (Benedict 1977). For a systematic study of western North American species, see Benedict (1977). Although a single "colony" of this genus may contaln 30 to 40 individuals, the total number of collectlons reported for any species is very small. Thus, relatively little is known about these possibly rare pseudoscorpions.

Apocheiridium bulbifemorum Benedict 1977

Geographical distribution. Oregon (Map 20). This very distinctive species is known from a single adult collected at $800 \mathrm{~m}$ in the Mixed 


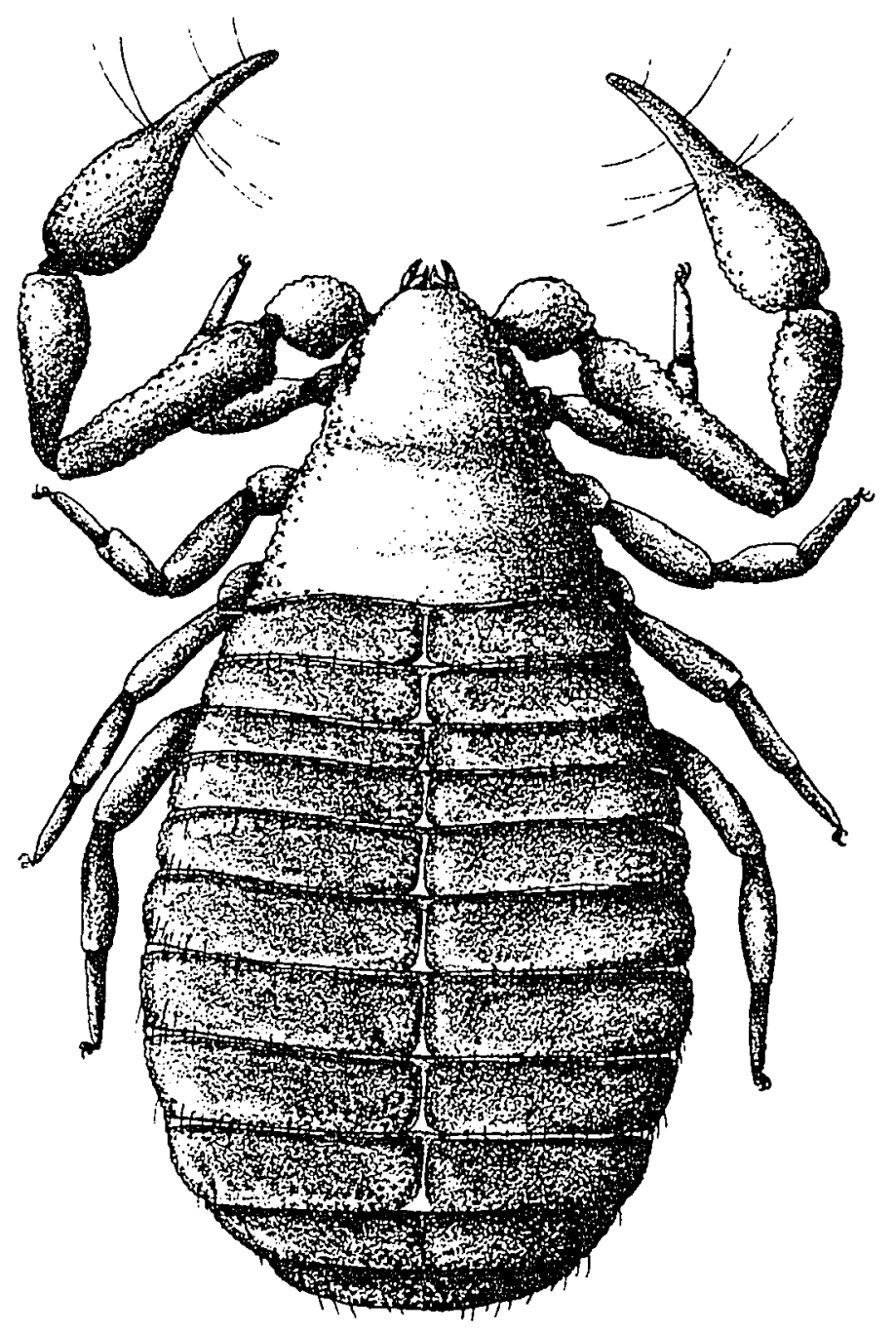

F1gure 7. Apochelridium fergusonl Benedict, a barkinhabiting cheiridild species from eastern Oregon. (Body length $1.3 \mathrm{mat}$ ). 


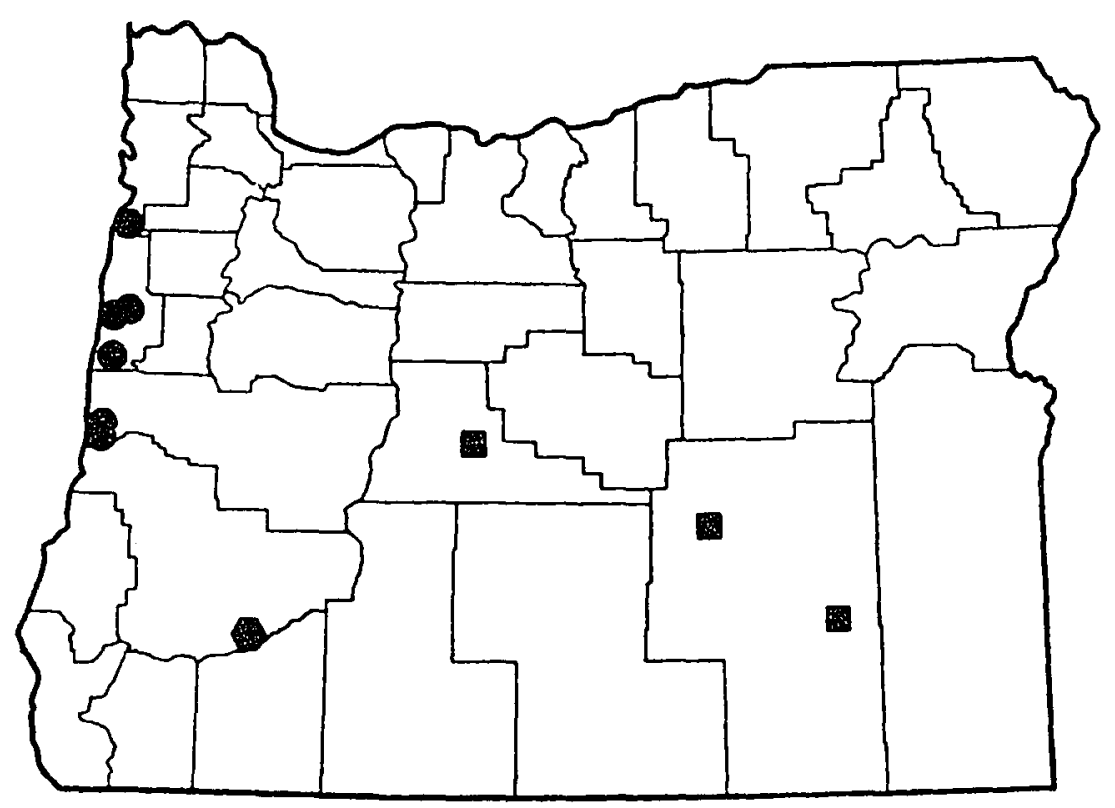

Hap 20. Distribution in Oregon: Apocheiridium bulbifemorum A. fergusoni , A. ferumoides .

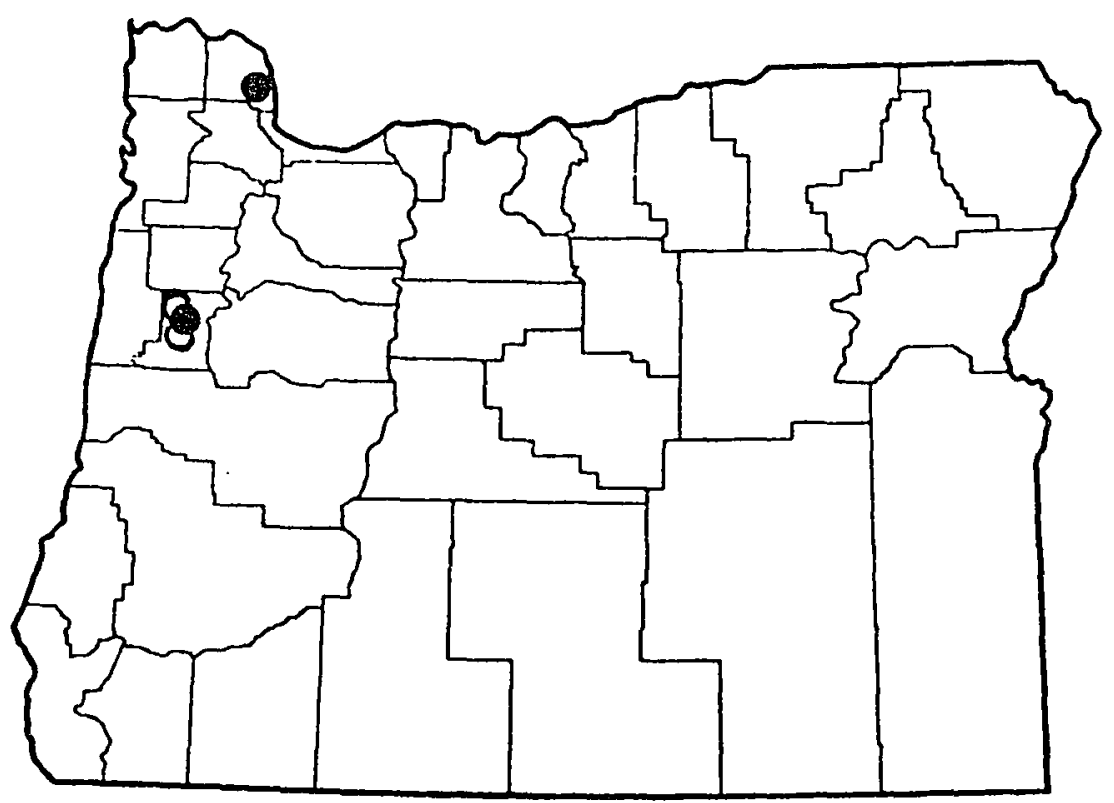

Man 21. Mistribution in Oregon: Apocheiridium granochelum A. mormon $O$. 
Contfer zone of Douglas County (Benedict 1977).

Habitat. Bark of a living sugar pine tree.

Seasonal distribution. An Oregon adult vas collected in September.

Remarks. See Benedict (1977) for a detailed description of this species.

Apocheiridium fergusoni Benedict 1977

Geographical distribution. Oregon (liap 20). This species is reported from four specimens collected in Harney and Deschutes Counties (Benedict 1977).

llabitat. Bark of living western juniper trees.

Seasonal distribution. Oregon adults were recovered in April, May and June, a nymph in April.

Remarks. See ienedict (1977) for a detailed description of this species.

\section{Apocheiridium ferumoides Chamberlin 1924}

Geographical distribution. Oregon (Map 20), California. This species is known from the coastal zone near sea level between Morro Bay and the Columbla River (Chamberlin 1924a, 1932; Benedict 1977). Oregon specimens were collected in the Sitka Spruce zone between Douglas and Clatsop Counties.

Habitats. Bark. California specimens came from bark of eucalyptus (Eucalyptus sp.), oak, cypress (Cupressus sp.), pine and coast redrood (Sequoia sempervirens (D. Don) EndI.) trees. Six Oregon collections were taken from bark of living sitka spruce, Douglas-fir and western red 
cedar.

Seasonal distribution. Oregon adults and nymphs were collected in February and March, nymphs in February. See Essig (1958) for photographs of molting and egg webs of $\underline{A}$. ferumoides. "Molting and egg webs are white silken disc-like, $2 \mathrm{~mm}$ in diameter; eggs white, irregular, somewhat globular, laid in groups of four within webs" (Essig 1958:11; Chamberlin 1924a).

Remarks. Published records suggest that $\underline{A}$. ferumoides occurs in two widely separated geographical areasi the coastal zone of Oregon and California (Chamberlin 1924a, 1932; Benedict 1977) and the Great Salt Lake Desert of Utah (Gering 1956). Benedict (1977) questioned the Utah determination since species of this genus superficially resemble each other and are, therefore, easily confused (Chamberlin 1924a). Utah specimens were unavailable for examination. See Benedict (1977) for a revised diagnosis and for measurements.

Apochelridium granochelum Benedict 1977

Geographical distribution. Oregon (Map 21). This species has been reported from three collections which were made during the $1930^{\prime}$ 's from the Interior Valley cones of Benton and Columbia Counties at elevations near $0 \mathrm{~m}$.

Habitats. Bark. The species is known from two collections from oak bark and one collection from Oregon ash bark (Benedict 1977). More than 30 samples of oak and ash bark were taken on one trip, alone, in Benton County in an unsuccessful attempt to locate the habitats of A. granochelum before it was described (Benedict 1977). The species was not collected during the present investigation. 
Seasonal distribution. Oregon adults were collected in February and March, nymphs in February.

Remarks. See Benedict (1977) for a detailed description of this species.

Apocheiridium mormon Chamberlin 1924

Geographical distribution. Idaho, Oregon (Map 21). Known for more than 50 years from a single specimen collected in Bear Lake County, Idaho, A. mormon was recently reported (Benedict 1977) from two collections made in the $1930^{\prime} \mathrm{s}$ in Benton County, Oregon.

Habitats. Bark. The Idaho specimen came from bark of mountain mahogany (Cercocarpus ledifolius Nutt. in $T \& G_{\bullet}$ ); Oregon specimens from under bark of oak and of an old fence post of an unknown species.

Seasonal distribution. Oregon adults were collected in February and March, nymphs in February. The fence post collection consisted of a colony of 37 adults and nymphs (Chamberlin Collection, unpubl. records).

Remarks. See Benedict (1977) for a revised diagnosis of this species, along with measurements.

SUPERFAMIIY CHELIFEROIDEA Chamber 1 in 1931

This superfamily is represented in the United States by three families, Cheliferidae Hagen, Chernetidae Menge and Atemnidae Chamberlin. Species of both the Cheliferidae and Chernetidae occur in Oregon.

FAMILY CHERNETIDAE Menge 1855

Chernetids (Fig. 8) are currently assigned to approximately onehundred poorly defined and confusing genera which Muchmore (1972b, 1974b, 1975b) is revising. Chernetids exhibit a nearly cosmopolitan distribu- 


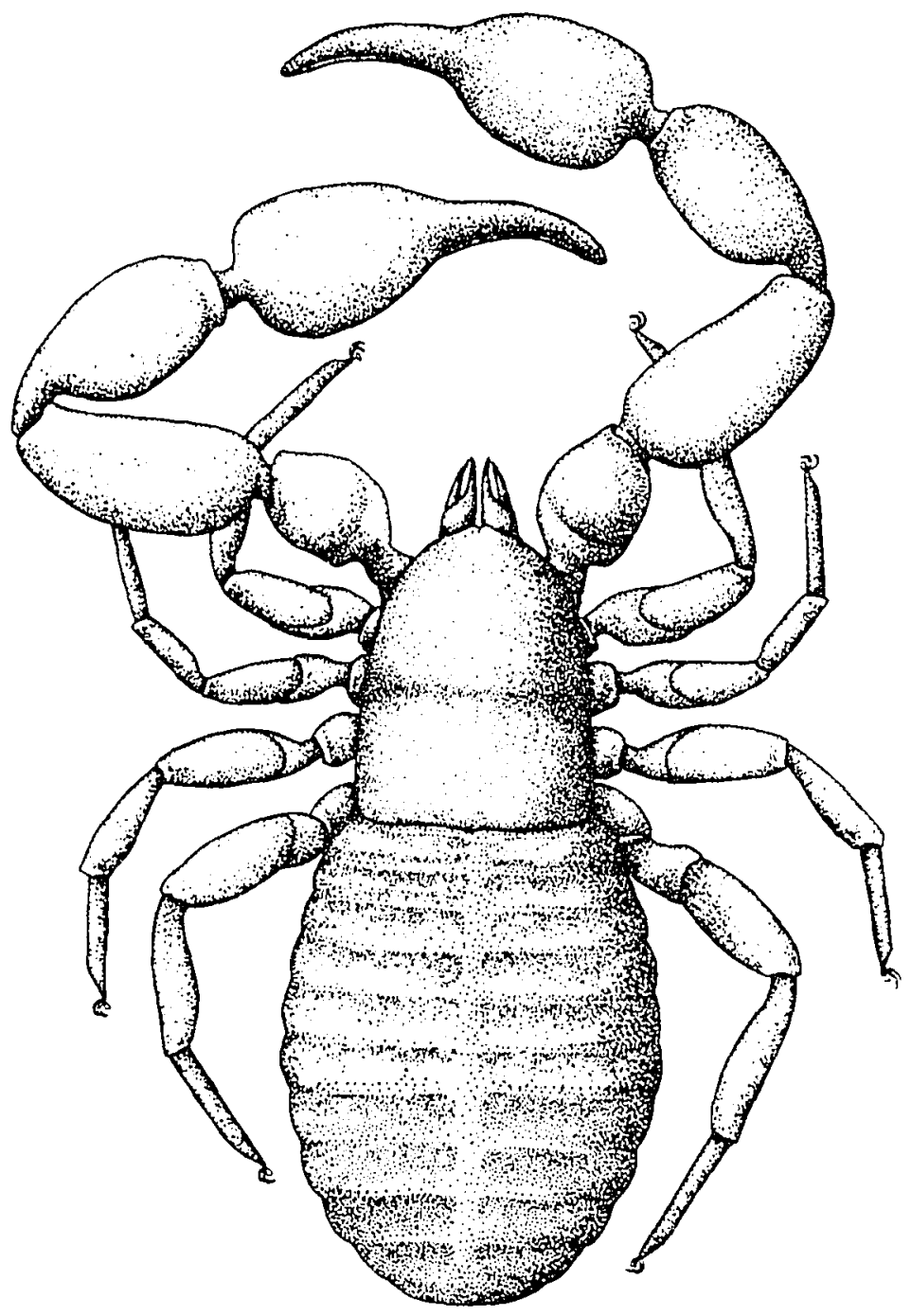

Figure 8. Illinichernes stephensi Benedict \& Malcolm, a tree hollow-inhabiting chernetid pseudoscorpion from western Oregon. (Body length 2.5-3.3 m). 
tion (Chamberlin 1931) and are the most diverse in form and size "in the torrid and the warm temperate zones" (Hoff 1959848), but also extend into cool temperate areas. Approximately 80 species have been reported from the United States, but none previously from Oregon. This is due to the perplexing systematis problems, not to a lack of chernetid specimens. Eight species are now being reported from Oregon: Acuminochernes crassopalpus (Hoff), Dendrochernes crassus Hoff, Dinocheirus sicarius Chamberlin, D. validus (Banks), Illinichernes stephensi Benedict \& Malcolm (1978c), Hesperochernes utahensis Hoff \& Clawson, Lamprochernes sp. and Lustrochernes grossus (Banks). These species, and the specimens upon which they are based, probably represent only a small part of the Oregon chernetid fauna.

\section{Acuminochernes Hoff 1949}

The single known Oregon specimen keys to A. crassopalpus (Hoff 1949, 1958) and exhibits the characteristics described by Hoff (1949), even though the closest reported localities are in the Great Plains states (Hoff 1945).

\section{Acuminochernes crassopalpus (Hoff) 1945}

Geographical distribution. Arkansas, Illinois, Kansas, Michigan, Oregon (Map 22). A specimen was collected from Sauvie Island, Multnomah County, Oregon (elevation near $0 \mathrm{~m}$ ).

Habitats. Rodent debris. The Oregon specimen came from debris collected from a tree hollow occupied by a California ground squirrel (Spermophilus beecheyi douglasii (Richardson)). In other states, this pseudoscorpion has been collected from the stomach of a red-bellied 


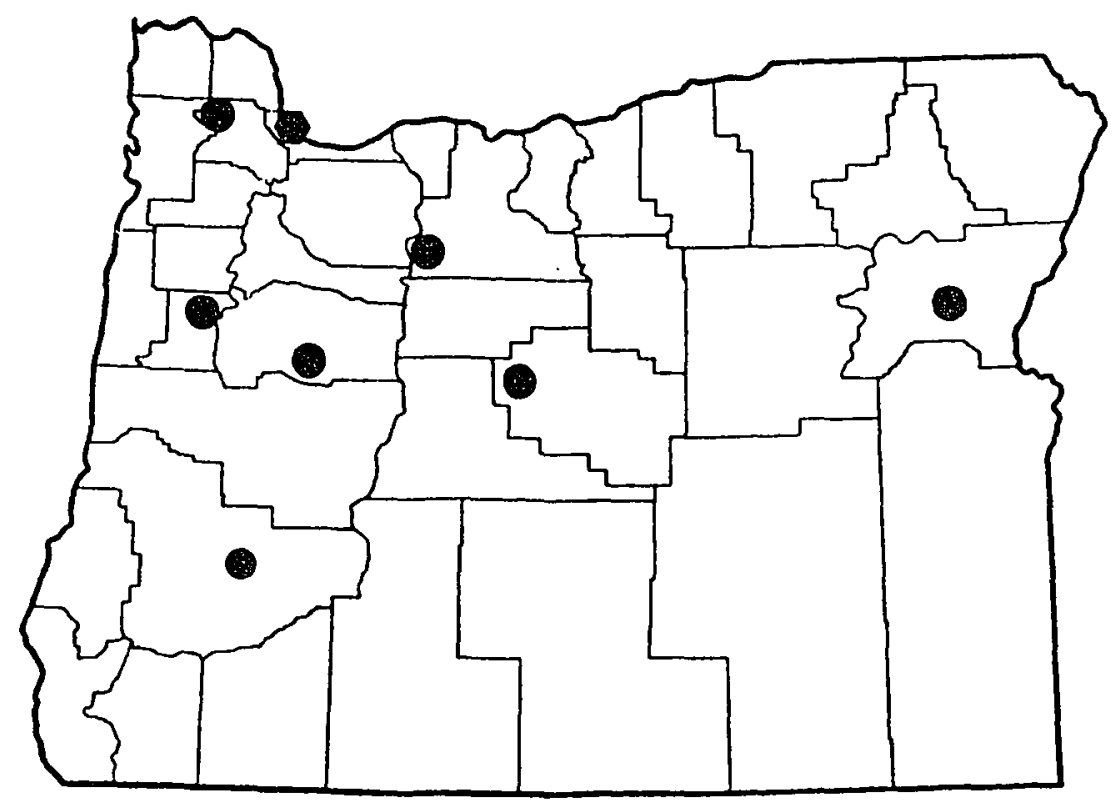

Hap 22. Pistribution in Cregon: Acuminochernes crassopalpus - Bendrochernes crassus 9

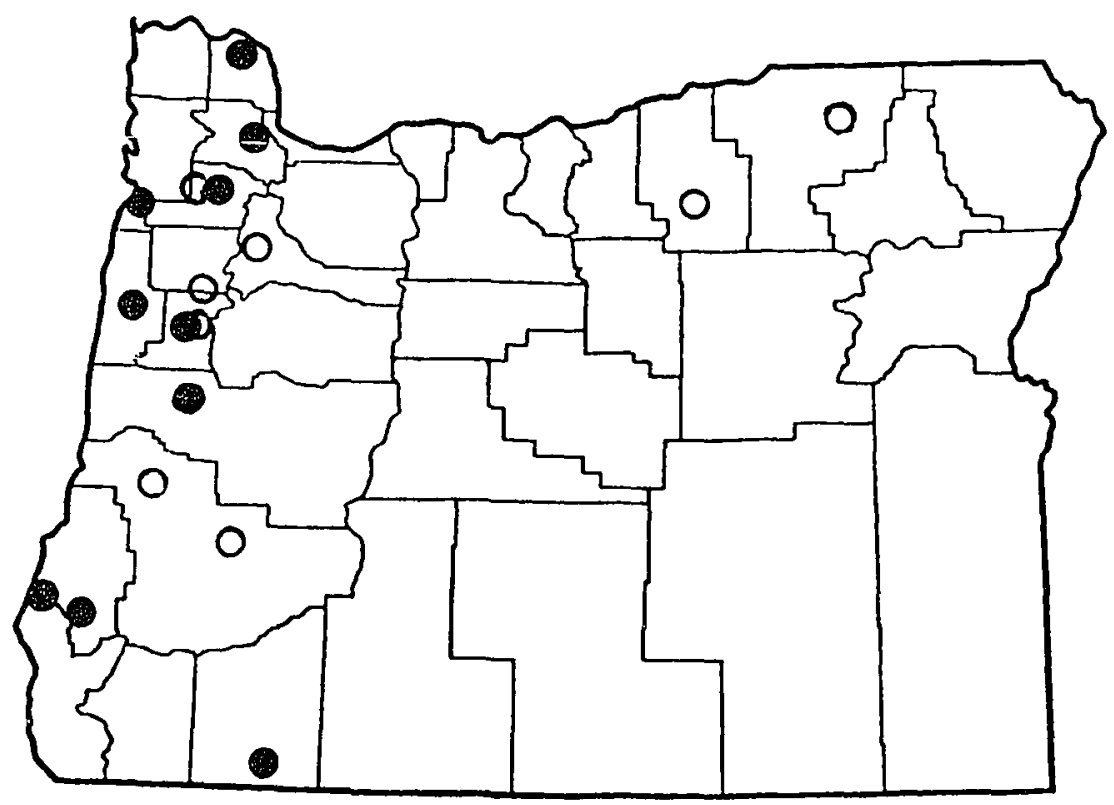

Ma' 23. Distribution in Oregon: Linochcirus sicarius Minocheirus validus $O$. 
woodpecker (Centurus carolinus (L)), a decayed $\log$ and from tree hollows (Hoff 1949; Nelson 1975).

Seasonal distribution. The Oregon adult was collected in October. Remarks. See Hoff (1945, 1949) and Nelson (1975) for detalled descriptive data concerning this species.

\section{Dendrochernes Beier 1931}

One species of this genus is now being reported from Oregon. See Hoff (1956c) for descriptive details of the genus.

\section{Dendrochernes crassus Hoff 1956}

Geographical distribution. New Mexico, Oregon (Map 22). This species is now reported from Oregon where it was collected in western Oregon in the Interior Valley Lone at elevations from $150-610 \mathrm{~m} \mathrm{in}$ Benton, Douglas, Linn and washington Counties. In eastern Oregon, it was collected in ponderosa pine areas from 760-1370 $\mathrm{m}$ in Harney and Crook Counties.

Habitats. Bark. Oregon specimens came from under bark of "dead" ponderosa pine and Douglas-fir, and under bark of a relatively "freshly fallen" ponderosa plne log (Chamberlin Collection, unpubl. records). One collector recorded restern pine beetles (Dendroctonus brevicornis Lec.) with D. crassus.

Seasonal distribution. Oregon adults were collected in March, Apr11, May and July, nymphs are unknown. Remarks. See Hoff (1956c, 1961) for descriptive details. 


\section{Dinochelrus Chamberlin 1929}

Two species, ‥ sicarius and ㅁ. validus, are now reported from Oregon. See Muchmore (1974b) for a revision of the genus.

\section{Dinocheirus sicarius Chamberlin 1952}

Geographical distribution. California, Oregon (Map 23), Utah. This species has been reported previously from California (Chamberlin 1952) and Utah (Gering 1956). Oregon specimens were collected at elevations from $0-610 \mathrm{~m}$ in farm areas.

Habitats. Domestic animal shelters. California specimens were collected from a barn, from barn owl (Tyto alba (Scopoli)) pellets, Neotoma spp. nests and middens, and attached to the trochanter of a muscid fly (Chamberlin 1952). No habltat data were given for the Utah specimens (Gering 1956). Oregon specimens came from domestic animal shelters, either currently or once occupled by cows, horses, sheep, pigs or fowl. ‥ sicarius was recovered in high numbers from litterdung samples from inside, under or within a meter of these shelters. This pseudoscorpion was present regardless of the condition of the bullding, the type of floor, or the molsture content of the debris. It was not, however, recovered from rain-weathered material removed from a former barn site, even though it occurred in samples taken from chicken house litter on the same farm.

Seasonal distribution. Oregon specimens were collected at all seasons of the year and many samples contained all life stages. Two of the May samples from Coos and Yamill Counties each included four females with egg masses of approximately 20 eggs each. 
Remarks. See Chamberlin (1952) for a detailed description of this species complete with excellent illustrations.

Dinocheirus validus (Banks) 1895

Geographical distribution. California, Colorado, New Mexico, Oregon (Map 23), Utah. This species has been reported previously from widely scattered localities between the Rocky Mountains and the Sierra Nevada Mountains (Banks 1895; Hoff 1947, 1956c, 1958, 1961; Knowlton 1972). Now it is reported from seven Oregon counties, where it occurs in the Interior Valley and Sitka Spruce Zones of western Oregon and in riparian communities of northeastern Oregon.

Habitats. Bark, tree hollows. California specimens came from bark near Lake Tahoe (Banks 1895), New Mexico specimens from bark of fir logs (Hoff 1956c, 1959), Colorado specimens from under bark of cottonwood logs and dead quaking aspen (Hoff 1961) and Utah specimens from under a $2 \times 4$ board in the sagebrush zone (Knowlton 1972). Western Oregon specimens came from samples of tree hollow debris (Oregon white oak, grand and white firs) and bark of a living tree (lodgepole pine). D. validus was also collected "on fly. In rotary flight trap. Upper net (5')" at Forest Grove, Washington County (Chamberlin Collection, unpubl. record). Eastern Oregon specimens came from bark of cottonwood. Seasonal distribution. Oregon adults were collected in January, March, April, May, August and September, nymphs are unknown. Remarks. See Hoff $(1947,1956 \mathrm{c}, 1961)$ for descriptive detal1s of this species. 
Hesperochernes Chamberlin 1924

One species of this genus is known from Oregon. See Nuchmore (1974b) for a revised diagnosis。

\section{Hesperochernes utahensis Hoff \& Clawson 1952}

Geographical distribution. Colorado, Idaho, New Mexico, Oregon (Map 24), Utah. This species was reported previously from the Rocky Mountain states (Hoff \& Clawson 1952; Hoff 1958, 1961; Know1ton 1972). Now it is reported from Harney County, Oregon, from two localities at elevations of $1220 \mathrm{~m}$ and $1700 \mathrm{~m}$ on the vestern slope of Steens Mountain in the Western Juniper Zone.

Habitats. Leaf litter. Utah specimens came from wood rat nests (Hoff \& Clawson 1952) and litter of juniper, rabbitbrush and sagebrush (Knowlton 1972), Idaho specimens from juniper litter (Knowlton 1972), Colorado specimens from 1itter, under rocks and wood in the pinyonjuniper zone (iloff 1961) and New Mexico specimens from juniper litter (Hoff 1956c). One Oregon collection came from $6 \mathrm{~cm}$ deep mossy-big sagebrush litter in an area roughly $16 \mathrm{~km}$ from the nearest tree. The other Oregon collection was recovered from $8 \mathrm{~cm}$ deep mountain spray litter accumulated on a talus slope overgrown with deciduous shrubs within a few meters of juniper trees.

Seasonal distribution. Oregon adults were collected in July and September, nymphs are unknown.

Remarks. See Hoff and Clawson (1952) and Hoff (1956c, 1961) for descriptive details. 


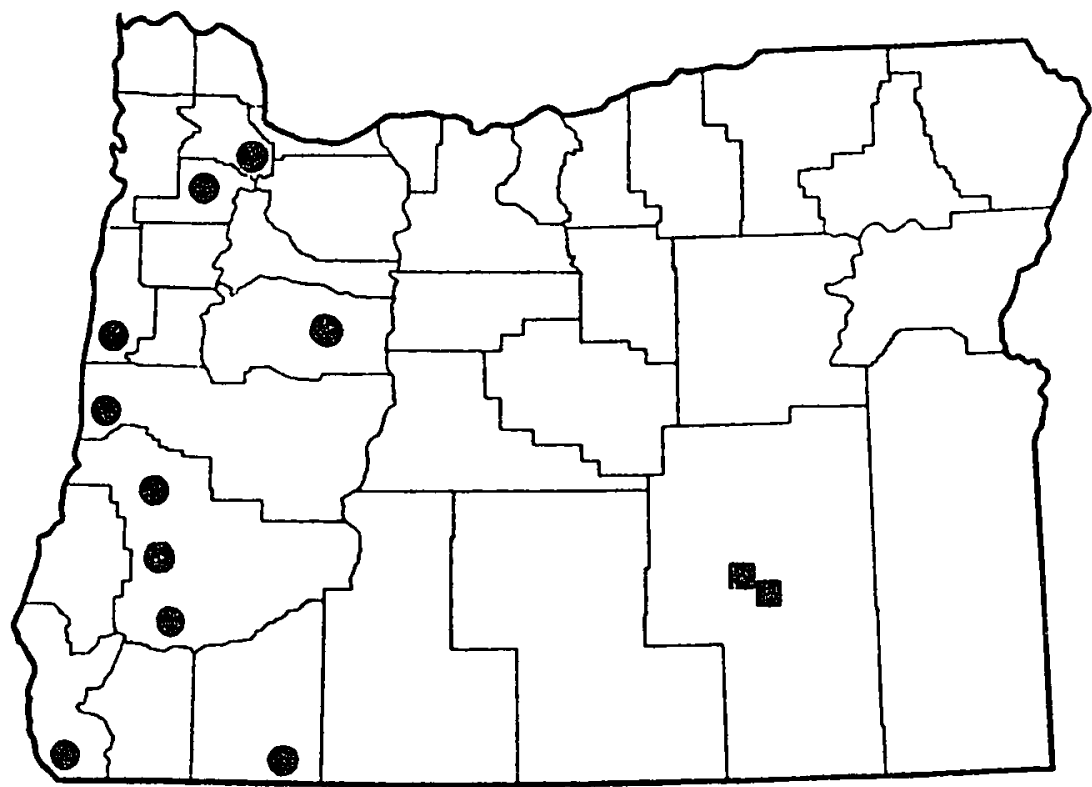

Mai 24. Mistribution in Oregon: lesperochernes utahensis , I11inichernes stephensi

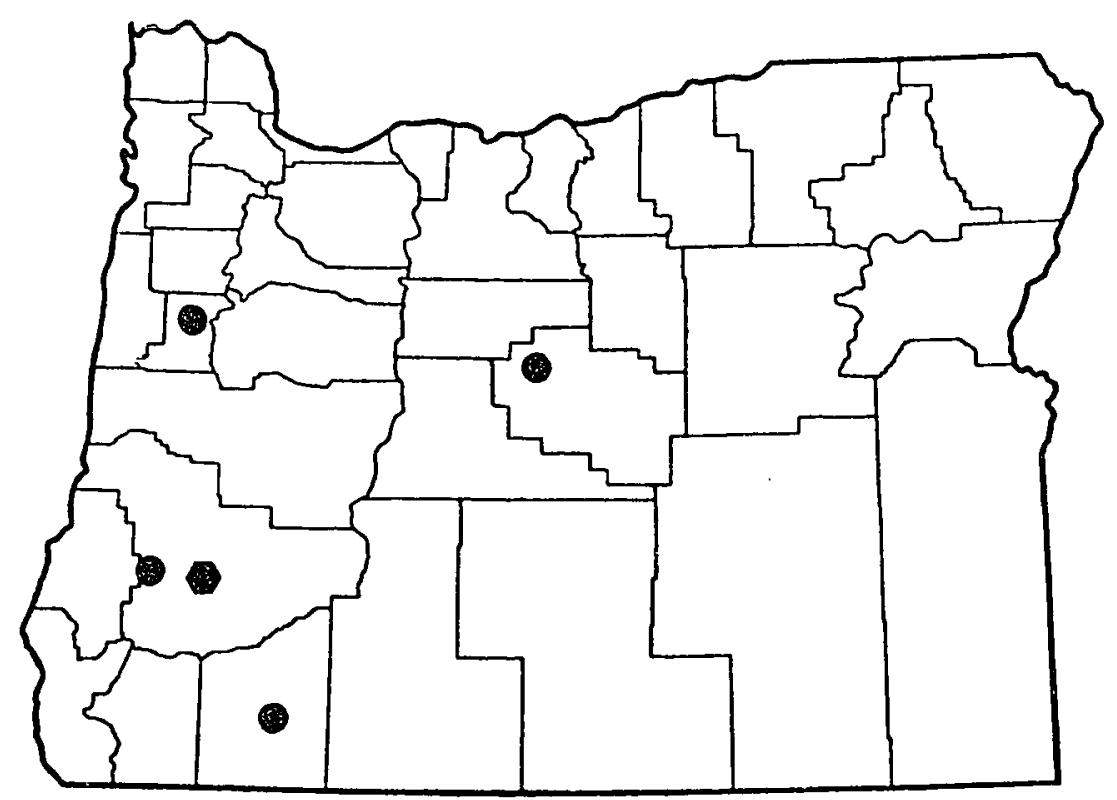

Vap 25. Nistribution in Cregon: Lamprochernes sp. Lustrochernes grossus . 


\section{Il1Inichernes Hoff 1949}

One species of this genus is being described from Oregon (Benedict \& Malcolm 1978c). See Hoff (1949) for descriptive detalls of this genus.

Il1inichernes stephensi Benedict \& Malcolm (in manuscript) Geographical distribution. Oregon (Map 24). This species is common in lowlands (elevations $50-550 \mathrm{~m}$ ) of the Interior Valley and Western Hemlock Zones of western Oregon; one collection came from an elevation of $1650 \mathrm{~m}$ at a locality $6 \mathrm{~km}$ north of the California-Oregon border.

Habitats. Tree hollows. All but two collections came from tree hollows (12 bigleaf maple, four grand fir, three California laurel, three tan oaks, two Oregon white oak, one red alder, one madrone). Samples were taken separately of material from the floor, walls and ceiling of hollows; I. stephensi occurred in all areas of a hollow. It inhabits both dry-rotted and wet-rotted wood, large and small hollows. It was recovered from two leaf litter samples (madrone, scrub white oak).

Seasonal distribution. Oregon adults and nymphs were collected during every month of the year. One June collection from Polk County contained a female with 13 external eggs, another female with 18 embryos, three males and several nymphs of various stages.

Remarks. This species is named after my father, Charles Lester Stephens. A detalled description is in manuscript (Benedict \& Malcolm 1978c). 


\section{Lamprochernes Tömösváry 1882}

At the present time this genus is known from Oregon from one specimen (Muchmore Collection) which has not been identified to species. See lloff (1956c) for descriptive detalis of the genus.

\section{Lamprochernes sp.}

Geographical distribution. Oregon (Map 25), Douglas County, Dixonville. This community is located in the Umpqua River portion of the Interior Valley Zone.

Habitat. No data except the microslide is labeled "Host-housefly". Seasonal distribution. This Oregon female was collected in September, nymphs are unknown.

\section{Lustrochernes Beier 1932}

One species of this genus is being reported from Oregon. See Hoff (1956c) for descriptive details of the genus.

\section{Lustrochernes grossus (Banks) 1893}

Geographical distribution. Arizona, Colorado, New Mexico, Oregon (Map 25). This species has been reported previously from three Rocky Mountain states (Banks, 1893; Hoff 1956c, 1958, 1961); now it is being reported from Oregon where it occurs at elevations from $0-1300 \mathrm{~m}$ in the Interior, Western Hemlock and Ponderosa Pine Zones.

Habitats. Bark. Hoff (1961) observed that this species in New Nexico and Colorado was usually collected in areas of ponderosa pine; no data are available on Arizona specimens. Oregon specimens came from bark of a Douglas-fir and a pine stump and a rotted log; two specimens 
were phoretic on cerambycid beetles. .

Seasonal distribution. Oregon adults were collected in March and Apri1, nymphs are unknown.

Remarks. See Hoff $(1947,1956 c, 1961)$ for descriptive details.

FAMILY CHELIFERIDAE Hagen 1878

Cheliferids (Fig. 9), practically cosmopolitan in distribution, (Chamberlin 1931) occur in drier areas (Beier 1932b; heygoldt 1969), or in drier habitats of mesic areas. Apparently, cheliferids obtain their greatest diversity in size and form in "the torrid and the warm temperate zones" (Hoff 1959:48). Most Oregon cheliferids have been collected in the drier habitats of animal or human shelters, or in the drier southwestern and eastern portions of the state.

Approximately 40 species of cheliferids have been reported from the United States with eight species recorded from Oregon. Banks (1895) gave a record for Parachelifer scabriculus (Simon) from Hood River which was one of the first records of pseudoscorpions from Oregon. Over 50 years elapsed before the next two cheliferid species were reporteds Hof (1950) provided records for Chelifer cancroides (L.) from Tillamook and Jackson Counties, and Chamberlin (1952) reported Haplochelifer philipl (Chamberlin) from four southern counties. Another quartercentury passed before the next five species were reported (Benedict \& Malcolm 1978b). Aspurochelifer 1ittlefieldi Benedict and Malcolm, Dactylochelifer silvestris Hoff, Hysterochelifer fuscipes (Banks), H. proprius Hoff, and $\underline{P}$ - persimilis (Banks). 


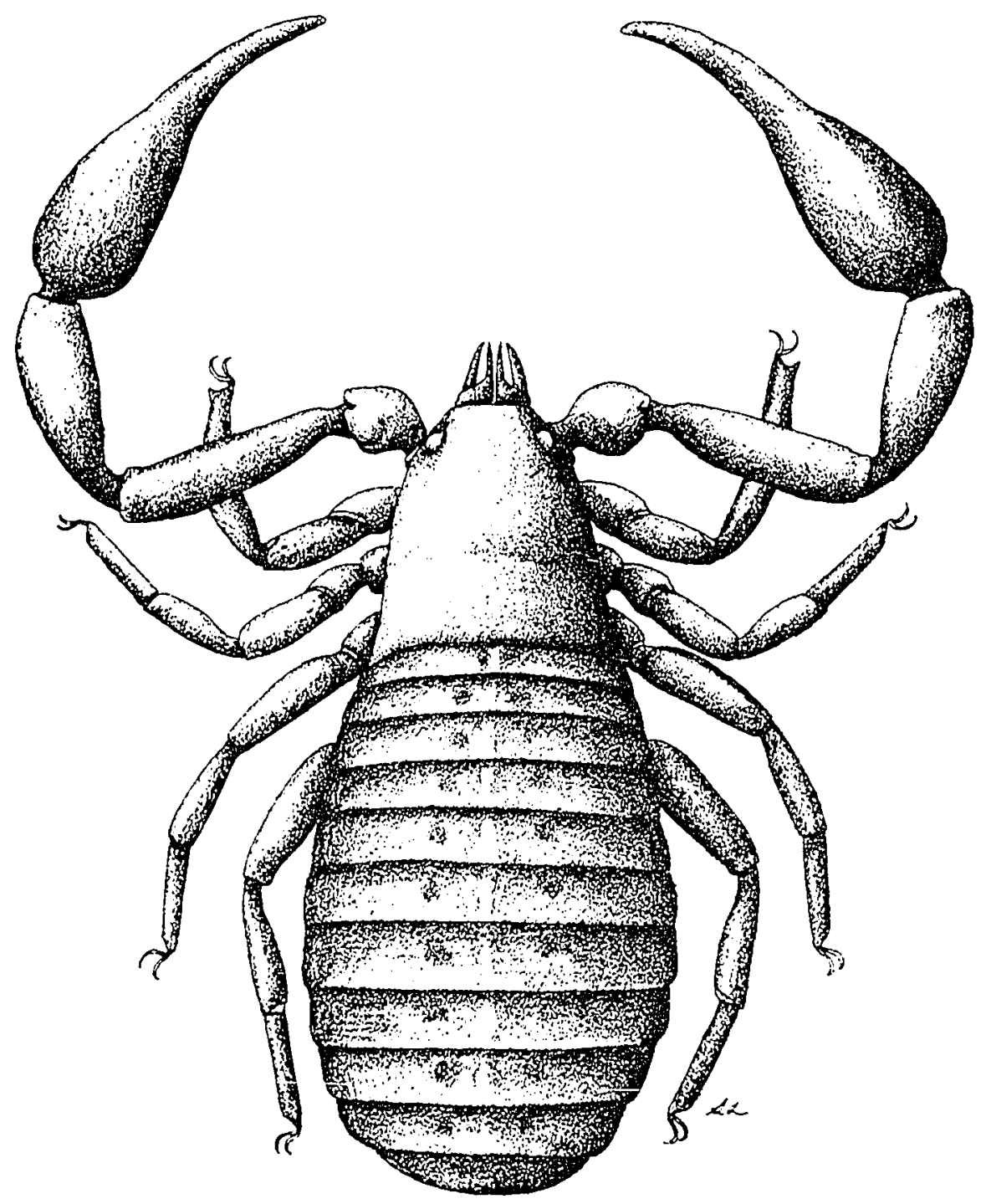

Figure 9. Aspurochelifer 11ttlefleldi Benedict \& Malcolm, a leaf litter-inhabiting cheliferid species from southern Oregon. (Body length 2-3 
Aspurochelifer Benedict \& Malcolm (in press)

One species of this genus is reported from Oregon. See Benedict and Malcolm (1978b) for a detailed description of the genus.

Aspurochelifer 1ittlefieldi Benedict \&Malcolm (in press)

Geographical distribution. California, Idaho, Oregon (Map 26), Nevada, V'ashington. This species was collected in Oregon at elevations from 360-1300 $\mathrm{m}$ in the Interior Valley Lone of Josephine and Jackson Counties, and at $1220 \mathrm{~m}$ in the riparian community along the Blitzen River in the Hestern Juniper Zone of Harney County.

Habitats. Leaf 1itter. Even though the species has been collected from five states, the only habitat data are for three of the four Oregon localities. This species was recovered from two samples of Oregon ash litter from riparian communities in Josephine and Jackson Counties, and from mountain alder litter in Harney County. Specimens occurred in both ground litter and in litter trapped between the multiple trunks of ash and alder trees.

Seasonal distribution. Oregon adults were collected in March, July, September and December. Females with an average of 16 embryos, non-gravid females, males, protonymphs and deutonymphs were collected at the Harney County site (Page Springs) in both July of 1971 and 1972.

Remarks. See Benedict and Malcolm (1978b) for a detailed description of this species.

Chelifer Geoferoy 1762

Chamberlin (1952) and Hoff (1956d) have characterized this monotypic genus in modern terms. 


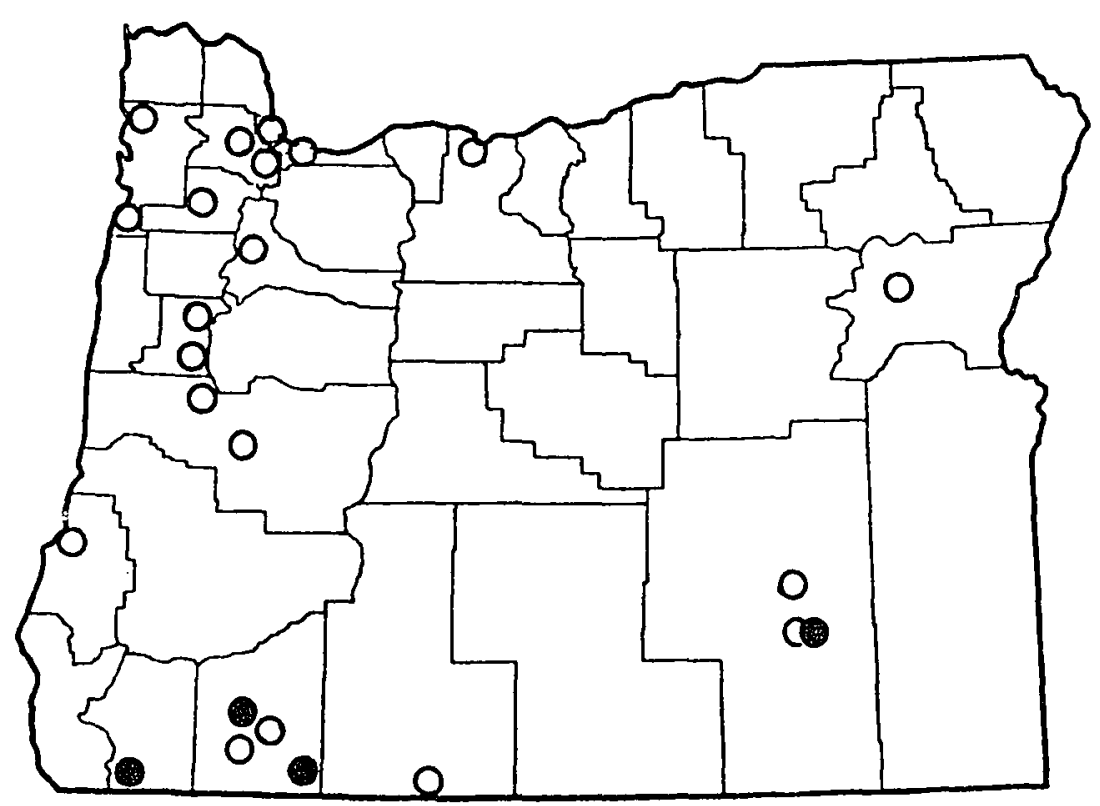

Nap 26. Distribution in Oregon: Aspurochelifer littlefieldi - Chelifer cancroicles $\mathrm{O}$.

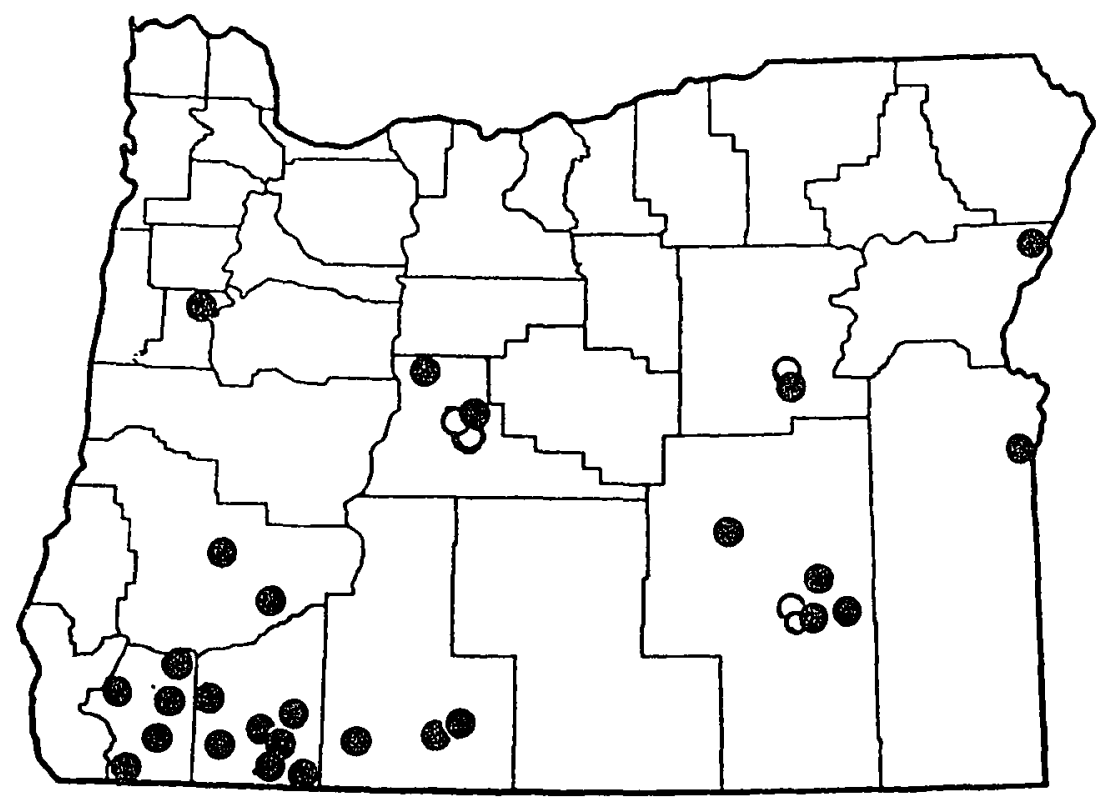

$\because 12$ 27. Distribution in Oregon: Dactylochelifer silvestris 0 , Iaplochelifer philipi 


\section{Chelifer cancroides (Iinnaeus) 1758}

Geographical distribution. Horldwide including Oregon (Nap 26). This pseudoscorpion is the species typically seen by the non-specialist because it inhabits human and domestic animal shelters (Hoff 1949, 1964; Ueygo1dt 1969). Hoff (1950) reported the first specimens from Oregon from Tillamook and Jackson Counties.

Habitats. Human habitations and domestic animal shelters. Sieveral Oregon collectors first became aware of pseudoscorpions by noticing a specimen of $\underline{C}$. cancroides in a bed or bathtub. Oregon specimens are recorded from houses on beds, bathtubs, books, dishes, and even on humans; from barns and sheds in the 1 itter-dung layer and in grain; from out-of-doors in grass clippings, under garage shingles, and in a swallow's nest (Hoff 1950; Benedict \& Malcolm 1978b). C. cancroides occurred in eight of my litter-dung samples, sometimes with the chernetid species, Dinocheirus sicarius.

Seasonal distribution. 'ieygoldt (1969) has cultured $C$. cancroides and provided developmental and $\mathrm{l}$ ife history data. Oregon adults and nymphs were collected during every season from the litter-dung layer, as well as from the other Oregon habitats from which this species is known.

Remarks. Unlike Hoff (1949) in Illinois, and Ressl and Beler (1958) in Austria, I did not recover specimens of $\underline{c}$. cancroides from bark or leaf litter in other than domestic situations. It is possible that the earlier records from non-domestic bark and leaf litter habitats pertain to another closely related genus such as Parachelifer Chamberlin. 
Dactylochelifer Beler 1932

One species of this genus is reported from Oregon (Benedict \& Malcolm 1978b). See Hoff (1956d, 1964) for descriptive details of the genus.

Dactylochelifer silvestris Hoff 1956

Geographical distribution. Colorado, Idaho, New Mexico, Oregon (Map 27), Utah. Oregon specimens are recorded from five scattered localities east of the Cascade Mountains at elevations from 1185-1375 m in the Ponderosa Pine, Sagebrush-Grassland and Vestern Juniper Lones.

Habltats. Leaf litter. Specimens from Colorado and New Mexico occurred in debris and 1 itter of various conifers and broad-leaf trees (Hoff 1956d, 196́1); from Utah and Idaho, in 1itter of Rocky Mountain juniper (Juniperus scopulorum Sarg.), sagebrush, greasewood (Sarcobatus vermiculatus (Hook•) Tor..), and rabbitbrush (Chrysothamnus spp•) (knowlton 1972); and from Oregon, in litter of big sagebrush, willow, green manzanita and ponderosa pine (Benedict \& Nalcolm 1978b). Knowlton (1972:1) observed that D. silvestris was "by far the most common species in Curlew Valley" of Utah and Idaho.

Seasonal distribution. Oregon adults and nymphs were recovered in March, May, July and December, with an adult only in January. One female, collected in July from Harney County, bore 12 embryos.

Remarks. See Hoff $(1956 \mathrm{~d}, 1961)$ for descriptive details of this species. 
iaplochelifer Chamberlin 1932

Chamberlin (1952) characterized this monotypic genus in modern terms, complete with detailed illustrations of Haplochelifer philipi.

Haplochelifer philipl (Chamberlin) 1923

Geographical distribution. Arizona, California, Colorado, Idaho, Nevada, New Mexico, Oregon (Map 27), Utah. Chamberlin (1952) reported the first Oregon specimens from five localities in Josephine, Jackson, klamath and Malheur Counties; it is now known from 24 additional localities in these and six other counties (Benedict \& Malcolm 1978b). habitats. Leaf litter. Throughout its range, it has been collected chiefly from 1 itter beneath pines, oaks, madrone and juniper; and from beneath rocks (Chamber1 in 1952; Hoff 1956d, 1961; Benedict \& Malcolm 1978b). Oregon specimens occurred in 38 collections of leaf litter, one hand-collection from under a board and two from under rocks. In western Oregon, it appears to be the most common cheliferid inhabiting, leaf litter, where it occurs at elevations from $0-1465 \mathrm{~m}$ in the interior Valley Zone between Benton County and the California-Oregon border. Here, it has been recovered mostly from the relatively dry, shallow 1itter of the oak-madrone-manzanita woodlands. In eastern Oregon, it was generally recovered from juniper and ponderosa pine litter at elevations from 900-1375 $\mathrm{m}$ in the kestern Juniper and Ponderosa Pine cones.

Seasonal distribution. Oregon adults and nymphs were collected during all seasons, often from the same collection.

Remarks. See Chamberlin (1952) for a detailed redescription 
including excellent 11 ust rations.

Hysterochelifer Chamberlin 1932

Two species, $\underline{H}$. Euscipes and $\underline{H}$ - proprius, occur in Oregon. A revision of the western North American species of this genus is current$1 \mathrm{y}$ in progress (Benedict \& Malcolm 1978d).

\section{Hysterochelifer fuscipes (Banks) 1909}

Geographical distribution. California, Oregon (Map 28), washington. The three Oregon collections were taken in 1936, 1940 and 1961 in the Interior Valley Lone of Benton County. Although "likely habitats" were sampled for this species, it was not recovered in any of the 2220 Berlese samples taken in this study.

Habitats. Records from a number of localities in the three Paciflc states will be reported which indicate that 1 . Euscipes occurs chlefly in relatively dry, chaparral type communities, where it has been collected from surfaces associated with living and dead shrubs and trees, including bark, mosses-lichens, leaf litter and the interior of cynipid galls (Benedict \& Nalcolm 1978d). The Oregon specimens were collected from a newly fallen log, moss on a silver popular tree (Popu1us sp.), and from "sweeping" undesignated material.

Seasonal distribution. Oregon adults were found in May, August and September.

Remarks. A detalled redescription of this species is in manuscript, based on a restudy of Banks' types (1969) and a number of specimens from various localities in the western United States (Benedict \& Malcolm 1978d). 


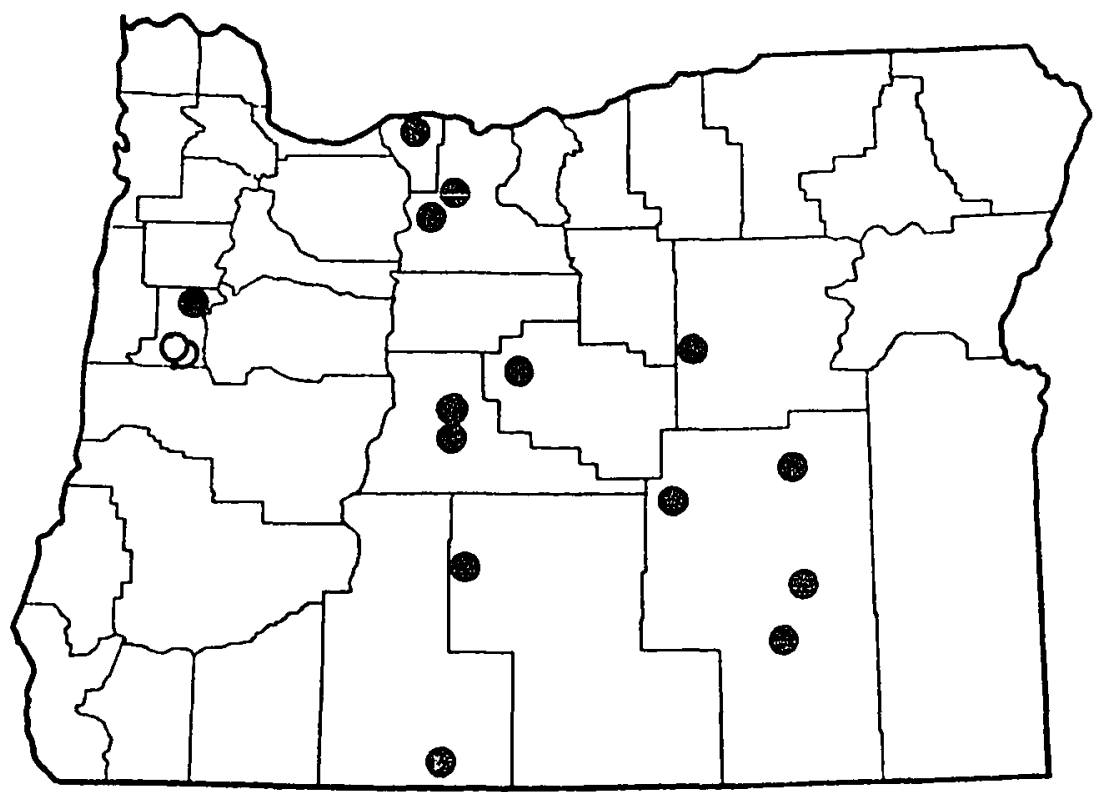

Aan 23. Distribution in Oreson: Iysterochelifer fuscipes $O$, i. Eroprius 9

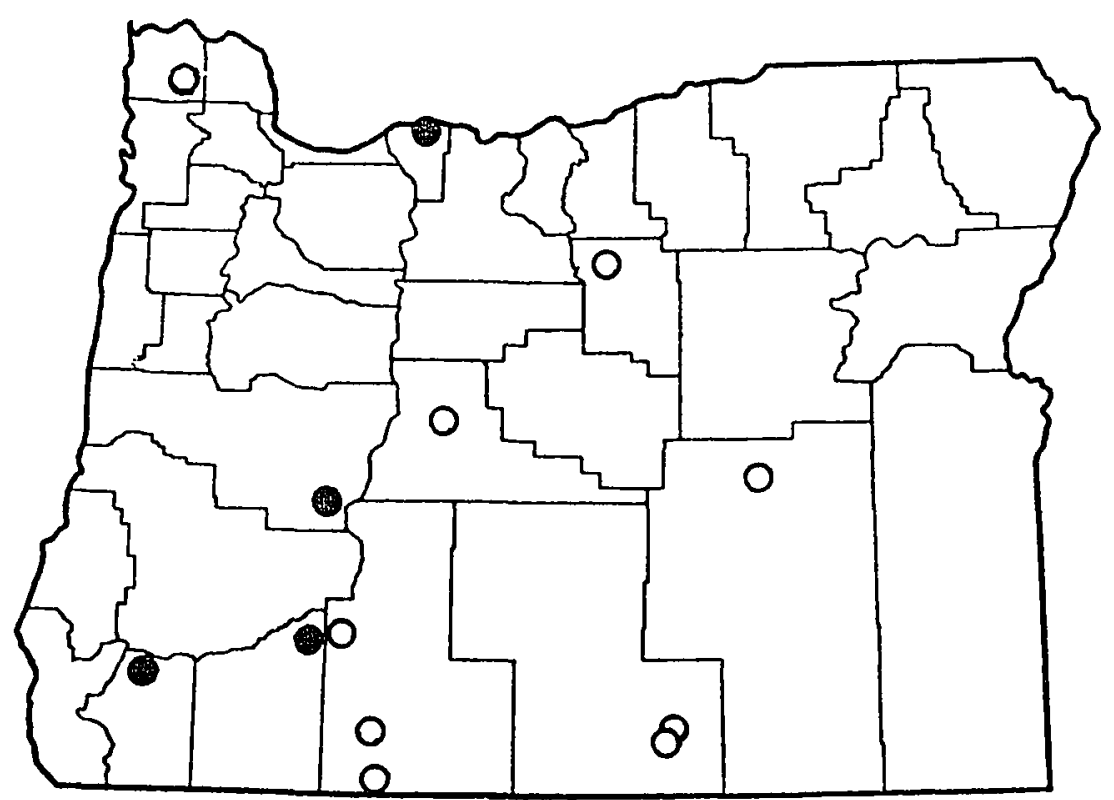

!:a2 29. Wistribution in Oregon: Parachelifer persimilis 0 , E. scabriculus . 


\section{Hysterochelifer proprius Hoff 1950}

\section{Geographical distribution. Arizona, California, Colorado, Idaho,} New Mexico, Oregon (Map 28), Utah, Washington. Prior to the recent study by Benedict and Malcolm (1978b) h. proprius was considered as rare (hoff 1961) since it had been reported only from a total of 11 specimens from Arizona, New Mexico and Colorado (Hoff 1950, 1956d, 1961). Now it is known to be widely distributed between the Rocky Nountain and Pacific states (Benedict \& Malcolm 1978b, 1978d). Oregon specime:is have been recorded from 22 localities, chiefly east of the Cascade Mountains.

Habitats. Throughout its range, 브 proprius was collected nost frequently from bark of juniper (Figs. 10, 11) and ponderosa pine, and more rarely from bark of mountain mahogany and birch. It was also collected from a soaptree yucca, the surface of a rock, "clothes drying on a line" (Hoff 1956d:12), and the stomach of a sagebrush lizard (Sceloporus graciosus (Baird \& Girard))。 Oregon specimens are known from 15 samples of bark from 1 iving western juniper and ponderosa pine trees, one hand-collection from the top of a rock under a juniper tree, and a "beaten" collection from a birch and from a pine. $\underline{\text { H. proprius }}$ is easily found by peeling exfoliating bark from trunks or branches of western juniper trees. The single western Oregon specimen came from a sample of ponderosa pine bark from the Interior Valley zone of Benton County.

Seasonal distribution. Oregon adults were collected every month between January and July and in October; nymphs were collected in Apri1, llay, September and October. A female (Jefferson County, Camp Sherman, 


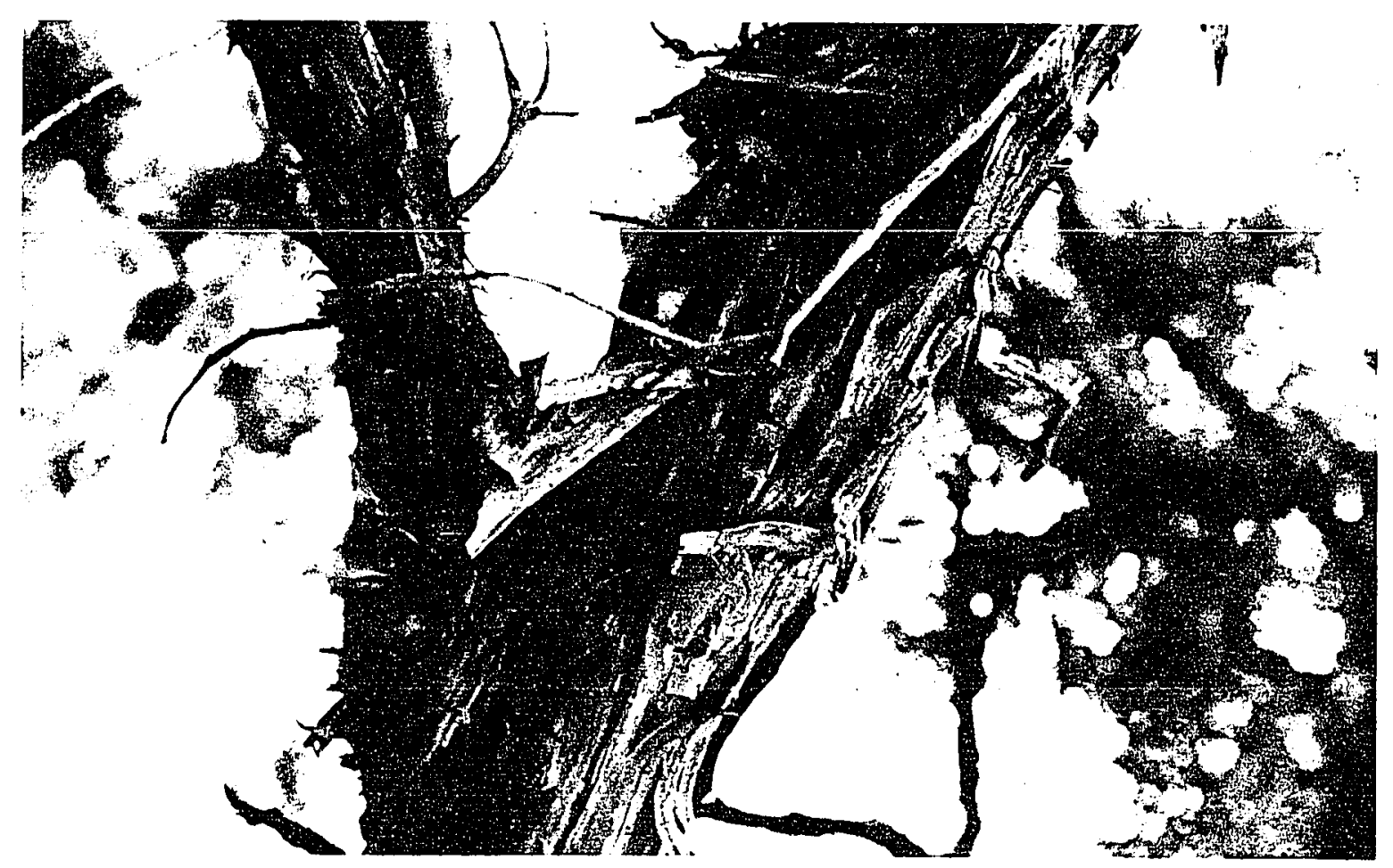

Figure 10. Exfoliating bark of Juniperus occidentalis Hook.

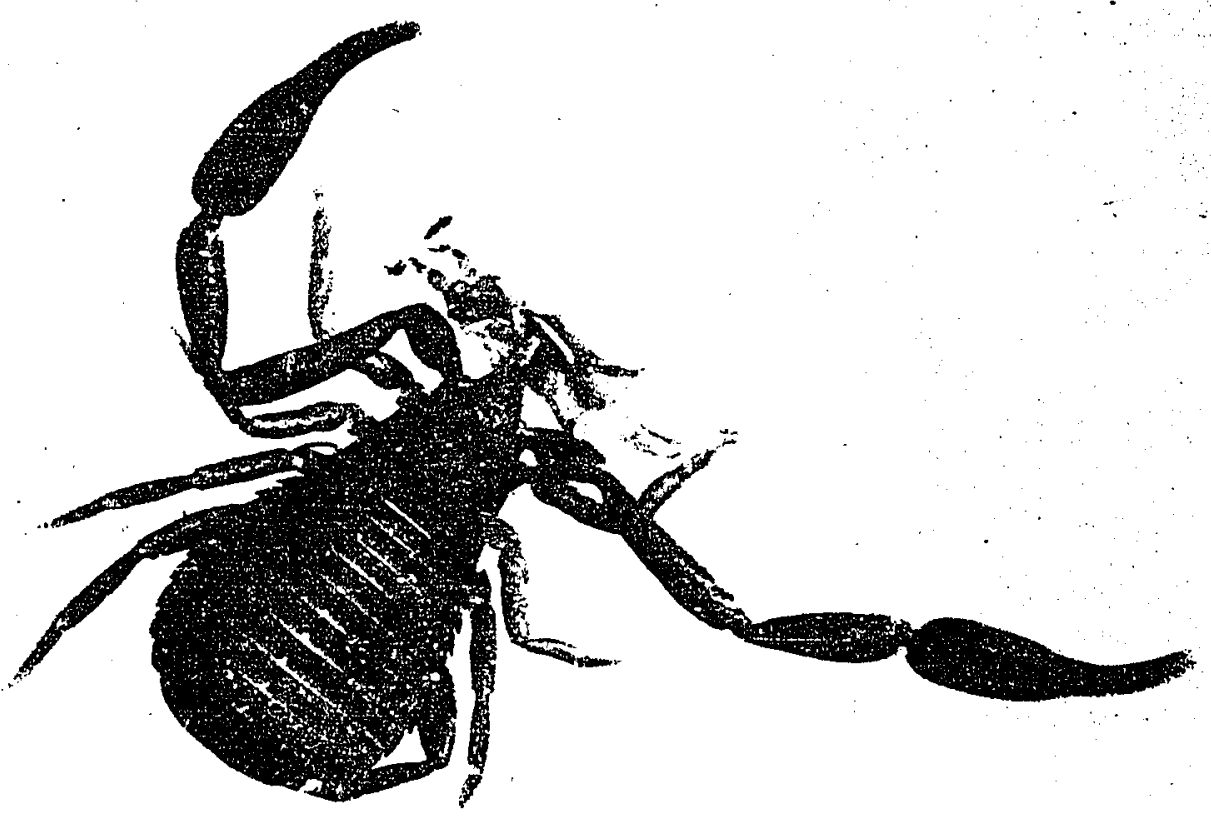

Figure 11. A laboratory specimen (male) of Hysterochelifer proprius Hoff feeding on a collembolan. 
14 May 1966, collected from a freshly fallen ponderosa pine log) survived in my laboratory for three months. On August 1st she produced four pale, green nymphs that escaped three days later. The male of the same collection died two weeks after capture.

Remarks. A detailed redescription of this species is in manuscript based on restudy of Hof 's types and an extensive series of specimens from widely-distributed localities of the western United States (Benedict \& Malcolm 1978d).

\section{Parachelifer Chamberin 1932}

Further study may reveal that Oregon specimens of this genus actually belong to a single highly variable species instead of the two species, $\underline{P}$. persimilis and $\underline{P}$. scabriculus, to which they have been assigned (Banks 1895; Benedict $\varepsilon_{6}$ Nalcolm 1978b). See Chamberlin (1952) for a detailed redescription of this genus, complete with illustrations

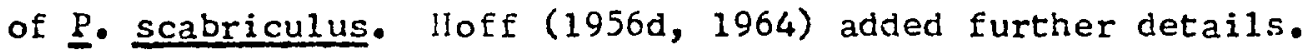

\section{Parachelifer persimilis (Banks) 1909}

Geographical distribution. Arizona, Colorado, Iontana, Nebraska, Nevada, New Mexico, Oregon (Map 29), South Dakota, Utah. Oregon specimens came from 15 "chance" collections from elght widely scattered localities at elevations from $0-2150 \mathrm{~m}$ in six counties.

Habitats. Bark. From states other than Oregon, this species has been collected most frequently from under bark of ponderosa pine stumps, logs, 1 iving and dead trees and less frequently from similar habitats of firs, spruce, pinyon and 1 imber pines and aspen. It vas also reported from the bark-debris at the base of a few trees, snags and stumps, in 
rock crevices, and on a cerambycid beetle. Oregon specimens were collected most frequently without adequate data concerning their habitats. Of the 15 collections, two lack any habitat data, four are recorded just "from bark", three from "bark of a ponderosa pine tree", one from "bark slab of ponderosa pine" and five phoretic on "cerambycid beetle". The three specimens from Crater Lake National Park were transported on separate nights $(8,10,17$ August 1960) to ultraviolet 1 ight by cerambycids. The Clatsop County specimen was on the body of a cerambycid ( 31 August 1963). Interestingly, the Lake County specimens came from an isolated relict ponderosa pine forest on Hart Mountain, a basin range block fault mountain, and were hand-collected from under ponderosa pine bark of a living tree, and from a flying cerambycid beetle. Twelve of the other collections also came from ponderosa pine areas. Thus, despite 1 imited data, it appears that Oregon specimens of P. persimilis exhibit a similar preference for ponderosa pine habitats as postulated for the species elsewhere (Hoff 1961).

Seasonal distribution. Oregon adults were collected in February, April, May, August and October; nymphs and adults in October.

Remarks. This species needs to be redescribed in detail based on a restudy of Banks' types and large series of specimens throughout its reported range.

\section{Parachelifer scabriculus (Simon) 1878}

Geographical distribution. Arizona, California, New Mexico, Oregon (Map 29), South Dakota, Utah. Historically, P. Scabriculus was one of the first pseudoscorpion species with a published record from Oregon, "Hood's River, Oreg॰, one specimen (Hubbard)" (Banks 1895:4). 
It is now known from three additional widely scattered localities in Oregon at elevations from 150-1525 In the Interior Valley, Hestern Hemlock and Mixed Conifer Zones.

Habltats. Bark. Throughout its range, $\underline{P} \cdot$ scabriculus has been reported chiefly from bark of declduous and conlferous trees (Hoff 1963). Although habltat data are wostly lacking, this species has been reported from Utah under stones (Banks 1895), froa California, under bark of dead pine, oak 10g8, and apple, eucalyptus and sycarore trees (Chamberlin 1952), and from South Dakota, from ponderosa pine infested with bark beetles (Hoff 1963). Oregon specimens are known frow bark of a conlfer snag, a living sugar pine and a Douglas-fir trae.

Seasonal distibution. Oregon adults were recovered in Aprll and Auguet, nymphs are unknown for the state.

Remark8. See Chamberiln (1952) for a detalled redescription of this specles based on a number of specimens from California. 


\section{DISTRIBUTION AREAS AND DISPERSAL OF OREGON SPECIES}

The individual species accounts provide the names of states from which species occurring in Oregon have been reported. Such a 1isting leads to speculation about mechanisms by which these small (body length, 1-7 $\mathrm{mm}$ ), flightless animals have spread over large geographical areas. It appears that pseudoscorpion species must be either very ancient, or have very efficient means of dispersal, or both. Therefore, known dispersal mechanisms, including examples of phoresy, are discussed below whlch may explain the observed distributional areas.

\section{DISTRIBUTIONAL AREAS}

According to Udvardy (1969:153) the term "distributional area" is preferred to "range" when "something less than the entire area of a species is under discussion." Such is the case for most western North American pseudoscorpion species as few localities have been thoroughly sampled. As collection data become available, interesting patterns emerge.

A case in polnt is the apparent distribution of Pseudotyrannochthonius incognitus and $\underline{P} \cdot$ gracilis in southwestern liashington, western Cregon and northwestern California (Map 30). ‥ incognitus, recovered in nearly 160 samples (Benedict \& Malcolm 1970; Benedict (oliection unpubl.), occurs in a nearly continuous area west of the Cascade Mountains except in two disjunct areas Inhabited by 


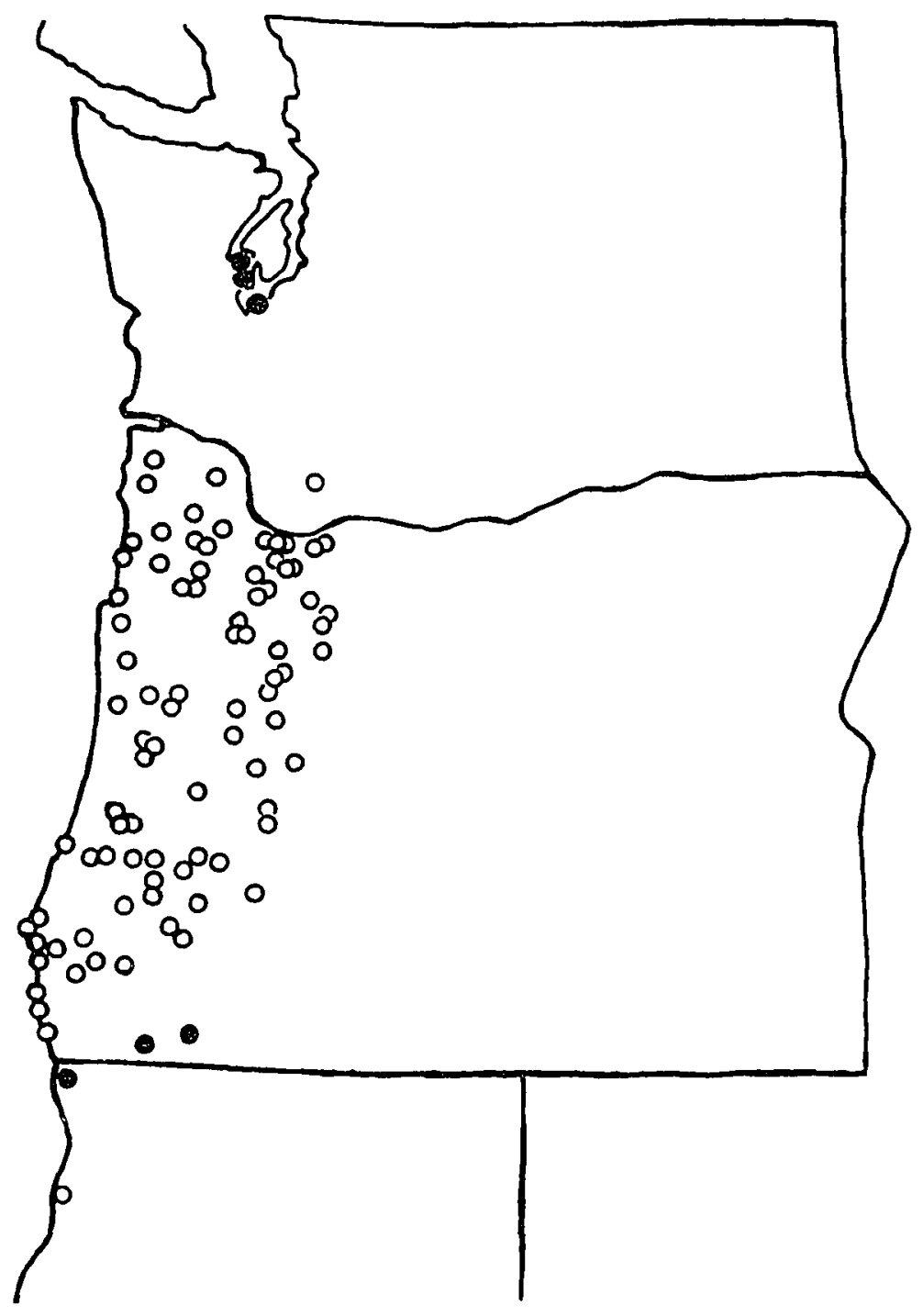

Map 30. Distribution in western Washington, western Oregon and northern Californias Pseudotyrannochthonius incognitus 0 ,

p. gracilis 
P. gracilis. P. gracilis, known from only seven collections (Benedict \& Malcolm 1970; unpub1. records, Benedict Collection), occurs in the lower Puget Sound area of hashington and in the Klamath-Siskiyou area along the Oregon-California border. Additional collections may, of course, provide intermediate records for both species. True disjunct distributions result from either relict populations or from recent colonizations (Nelson 1971; Udvardy 1969).

Conclusions based on the current knowledge of pseudoscorpion distributions are only tentative as several major problems exist. For example, several species are probably invalid taxonomically due to too broad or too narrow species definitions. Even when species are adequately defined, one or more specimens may have been $\mathrm{mis}-$ identifled and are now unavailable for reexamination. Species may be reported from too few localities and/or from specimens collected in a "hit-or-miss fashion" without accurate locality or habitat data. Range maps and lists may suggest that a species occurs statewide when it actually inhabits a very limited area. Any of these problems can distort the apparent distributional area or range of a species. With these limitations in mind, the following Oregon species are grouped according to distributional areas somewhat similar to the ones devised by Nelson (1971) for Michigan species.

a. Vorld wides Chelifer cancroides.

b. Midwestern through Pacific states: Acuminochernes crassopa1pus.

c. viestern edge of Great Plains through Pacific States: Lechytia hoffi, Parachelifer persimilis, $\underline{\text { P. Scabriculus. }}$ 
d. Rocky Mountains through Pacific statesi Apochthonlus occidental is, Archeolarca rotunda, Larca notha, Pseudogarypus bicornis, Dendrochernes crassus, Dinocheirus sicarius, Dactylochelifer silvestris, Haplochelifer philipi, Hysterochelifer proprius.

e. Pacific slope: Apocheiridium ferumoides.

f. Pacific coastline: Halobistum occidentale.

g. Pacific Northwest: Pseudogarypus hesperus.

h. Southwestern Oregon and northern California: Neochthonius amplus, Malcolmochthonius malcolmi.

1. Two disjunct areas (Pugest Sound area, Washington; Klamath Mountains of Oregon and California): Pseudotyrannochthondus gracilis.

j. One locality (possible endemic specles) Redmond Cave: Parobisium charlotteae; Malheur Cave: Apochthonius malheuri; sink of Charcoal Cave No. 1: Apochthonius forbesi.

Other Oregon species probably exhibit similar patterns but are known from too few localities or collections to categorize at this time.

DISPERSAL OF PSEUDOSCORPIONS

Although the distributional areas outlined may not reflect the actual ranges of the species involved, it is useful to discuss dispersal mechanisms which could account for such distributions. Mechanisms include phoresy, human activities and air currents (Nelson 1971).

Phoresy, defined as a "nonparasitic association of one kind of 
animal with another which results in the transportation of the smaller by the larger" (Muchmore 1971:95), is the usual means postulated by which pseudoscorpions disperse. According to Nuchmore, phoresy is the accidental by-product of predation. The pseudoscorpion in search of food attaches to a larger animal ("host") and is accidentally carried to another locality.

Oregon species observed in some part of their range attached to or on other animals ares

Chelifer cancroides, one male and one female on a human, Benton County, Oregon, reported by Benedict \& Malcolm (1978b)

Dinocheirus sicarius, one female clinging to trochanter of third leg of a muscid fly, Monterey County, California (Chamberl in 1952).

Dinocheirus validus, one female on a fly, lashington County, Oregon (unpubl. record, Chamberlin Collection).

Hysterochelifer fuscipes, one female attached by right chela to left second leg of a bostrichid beetle (Psoa quadrisignata Horn), Marin County, California (Benedict \& Malcolm 1978d). Lamprochernes sp., one female on a housefly (Musca domestica I.), Douglas County, Oregon (unpubl, record, Muchmore Collection).

Larca chamberlini, one male on a mosquito, Yuba County, California (Benedict \& Malcolm 1977); one female on abdomen of a hibernating mosquito, Benton County, Oregon (unpubl. record, Chamberlin Collection). 
Lechytia hoffi, one male and one female clinging to hind tarsus of a small beetle (Prostomis mandibularis Fabr.), Santa Cruz County, California (Nuchmore 1975a).

Lustrochernes grossus, two females clinging to dorsal abdominal setae of a male giant crab spider (ollos fasciculatus Simon), Gila County, Arizona (Hoff \& Jennings 1974); two females under elytra of a cerambycld beetle, "Oregon" (unpubl. record, Chamberlin Collection); flve adults "ex." cerambycid beetles (Ergates spiculatus spiculatus LeConte), Benton County, Oregon (unpubl, record, Benedict Collection); nine males, ten females on E. spiculatus, Coconino County, Arizona (Muchmore 1971).

Mundochthonius sp., one male attached by the right chelicera to fourth left leg of a small centipede, Tillamook County, Oregon (unpubl. record, Benedict Collection).

Parachelifer persimilis, five males, seven females on cerambycid beetles (E. spiculatus), Coconino County, Arizona (Muchmore 1971); two males, two females under elytra of a prionine cerambycid (Tragosoma depsarium (L.)), Sandoval County, New Mexico (Muchmore 1971); one male, two females on separate cerambycids (Ortholeptura valida LeConte), Crater Lake National Park, Oregon (Benedict \& Malcolm 1978b); one female on a cerambycid, Clatsop County, Oregon (Benedict \& Malcolm 1978b); one male, one female attached to a leg of a cerambycid (Brachyleptura canadensis Kirby), Hart Mountain, Lake County, Oregon (Benedict \& Malcolm 
1978b).

Thus, specimens of ten pseudoscorpion species reported from Oregon have been collected in some part of their range either on or attached to another animal. It may be questioned whether the specimen of C. cancroldes on a human is a case of phoresy, but it fits Muchmore's definition of being on a larger animal and could have been transported. The pseudoscorpion (Mundochthonius sp.) attached to the centipede may have been feeding since the fingers of the chelicera had penetrated the exoskeleton of the centipede's leg and disrupted the tissues. Pseudoscorpions of five species have been recorded as phoretic on insects in Oregons Lustrochernes grossus and Parachelifer persimilis on cerambycid beetles, Dinocheirus validus and Lamprochernes sp. on flles, and Larca chamberlini on mosquitoes. The beetles carrying P. persimilis were collected in flight.

Phoresy, according to Veygoldt (1969) and Muchmore (1971), is observed mostly among the chernetids and cheliferids, less often among species of other families, and almost never among neobisilds and chthonids. This may relate to the fact that many chthonilds and neobisids inhabit moist roody plant litter and do not come into contact with suitable "host" animals (Beier 1948; Nuchmore 1971). Another interpretation is that these pseudoscorpions would desiccate if flown through the alr, thus, phoresy would be disadvantageous. The only chthonild reported as phoretic by Nuchmore was Lechytia hoffi. It inhabits bark and relatively dry litter, and consequently, would not desiccate as easily as pseudoscorpions from other habitats. The heavily-sclerotized chernetids and cheliferids also typically occur 
in the drier habltats. See Müller (1960) and lieygoldt (1969) for photographs of a chernetid attached to a braconid hymenopteran embedded in amber of 01 igocene age.

Humans apparently serve as indirect transporters of pseudoscorplons during movement of domestic animals and plant materials throughout the world (Muchmore 1963, 1969b, 1972a; Weygoldt 1969). Chamberlin (1938) reported instances of interception of pseudoscorpions at quarantine stations. One specimen of the European species, Allochernes peregrinus Lohmander, was recovered from New Hampshire and is considered an import by Muchmore (1972a). Two European species, C. cancroides and Cheirldium museorum (Leach), appear established in the United States through the transport of domestic animals (Muchmore 1973). Two other European species, Chthonius tetrachelatus (Preyssler) and Roncus lubricus L. Koch, occur in and around Rochester, New York, and may have been imported with nursery stock (Muchmore 1963). Neison (1971:45), however, reported $\subseteq$. tetrachelatus as "widely distributed in the eastern part of the United States from Georgla to Miaine, and as far west as Illinols." Possibly C. tetrachelatus is a relict of the time approximately 100 million years ago when the North American and Euraslan plates were joined (Kürtén 1969) and not a recent import at all. The other three European specles were not reported from the southeastern states (Lawson 1968) nor from Michigan (Nelson 1971). They probably represent recent introductions.

Little is known of the dispersal of leaf litter-inhabiting chthonilds and neobisilds. A fast-moving arthropod, i.e., the centi- 
pede ( $5.6 \mathrm{~mm}$ body length) to which the specimen of Nundochthonius sp. (1.2 mm body length) was attached, certainly could disperse pseudoscorpions through leaf litter. Nelson (1971) suggested that chthonilis and neobisilds are dispersed by air currents, but Lawson (1968:214) cast doubt on this idea since "their secluded habitat would protect them from high winds." I have seen leaf litter blown from hilltops. This sight suggests that wind dispersal could be a factor. Whatever the means, these tiny pseudoscorpions are certainly widely distributed.

\section{ANCIENT ORIGIN OF PSELDOSCORPIONS}

According to Savory (1968) conditions in cryptozoic habitats probably have not changed appreciably for millions of years and thus have not produced much selective pressure for change. If true, then the distributional areas observed for pseudoscorpion species can be explained by the long passage of time during which a species could disperse. Udvardy (1969) noted that species of other taxa with broad distributions or with disjunct distributions were ancient, spreading initially from very small centers to their present areas. Hoff (1959) presented an interesting discussion of the adaptive radiation of pseudoscorpion families. Savory (1964:107) noted that pseudoscorpions "are found everywhere except in the frigid regions of the Arctic and Antarctic."

Normally, if one wishes to suggest an ancient origin for a specles, evidence is gathered from fossils. However, pseudoscorpion fossils are rare, even though modern genera, including Pseudogarypus (Beler 1937; Roewer 1940; Savory 1964), were preserved in Oligocene 
age ambers. Other closely-related arachnids were preserved among the earliest 1 and invertebrates. Scorpions occur in formations of Silurian age and mites (Acari) in formations of Devontan age (Savory 1964). It is reasonable to think that pseudoscorpions are equally ancient but generally were not fossilized due to their habltats. 


\section{HABITATS OF OREGON PSEUDOSCORPIONS}

This is the second major work from the United States with a detailed analysis of pseudoscorpions and their habitats. As background, the following information about Oregon blotic provinces is provided.

\section{BIOTIC PROVINCES OF OREGON}

Five major biotic provinces merge in Oregon, producing one of the more diverse states of North America in terms of environment and vegetation (Franklin \& Dyrness 1973) and hence blotic communities. Three of these provinces intergrade in western Oregon--the mesic temperate coniferous forests typical of Washington and northwestern Oregon, the sclerophyllous forests of the Coast Ranges of California and southwestern Oregon, and the mixed coniferous forests of the Sierra Nevada and the interior of southwestern Oregon. The forests of eastern Oregon are primarily of the Rocky Mountain type, dominated by ponderosa pine and white fir, with western juniper on drier sites. Shrub-grass communities of the Great Basin occur in central and southeastern Oregon. This biotic diversity is difficult to classify ecologlcally because indefinite boundaries exist between communities, and because natural vegetation has been disrupted by logging, clearing, burning and grazing (Franklin \& Dyrness 1973). 
HABITAT RELAT IONSHIPS OF OREGON SPECIES ACCORDING TO SUBORDERS

Heterosphyronid and diplosphyronid pseudoscorpions typically

occur in soil-leaf litter and deep subterranean habitats, while monosphyronids are more typical of bark, rotted wood, animal nests and debris, domestic animal shelters and human habitations (Hoff 1959; Chamberlin \& Malcolm 1960; Lawson 1968; Nelson 1971; Muchmore 1973). Tables III to $V$ include the 50 identified Oregon specles 1 isted by habitats using the format of Nelson (1971). Habitat relationships of species to higher taxonomic categorles shown in these tables will be more evident once the remaining Oregon specimens are identifled to species, since most unidentified specimens are diplosphyronids from leaf litter habitats.

In the meantime, 27 Oregon species have been identifled from woody plant litter, 20 from bark, seven from tree hollows, four from rotted wood, nine from epiphytes, six from under or on rocks, three from under boards, flve from a cave or a wel1, five from animal nests, two from domestic animal shelters, two from human habitations, and one from an outhouse. Seven species were collected phoretically in Oregon.

HABITAT SPECIFICITY OF OREGON PSELDOSCORPION SPECIES

Pseudoscorpion species from Oregon are difficult to classify ecologically as a number of the species occur in several vegetational zones (Appendix II) and in a variety of habitats (Tables III-V) in these zones. Even though it is premature to list species according to particular sites, given the current systematic problems and lack 
TABLE III

OREGON HABITATS OF HETEROSPHYRONID PSEUDOSCORPIONS

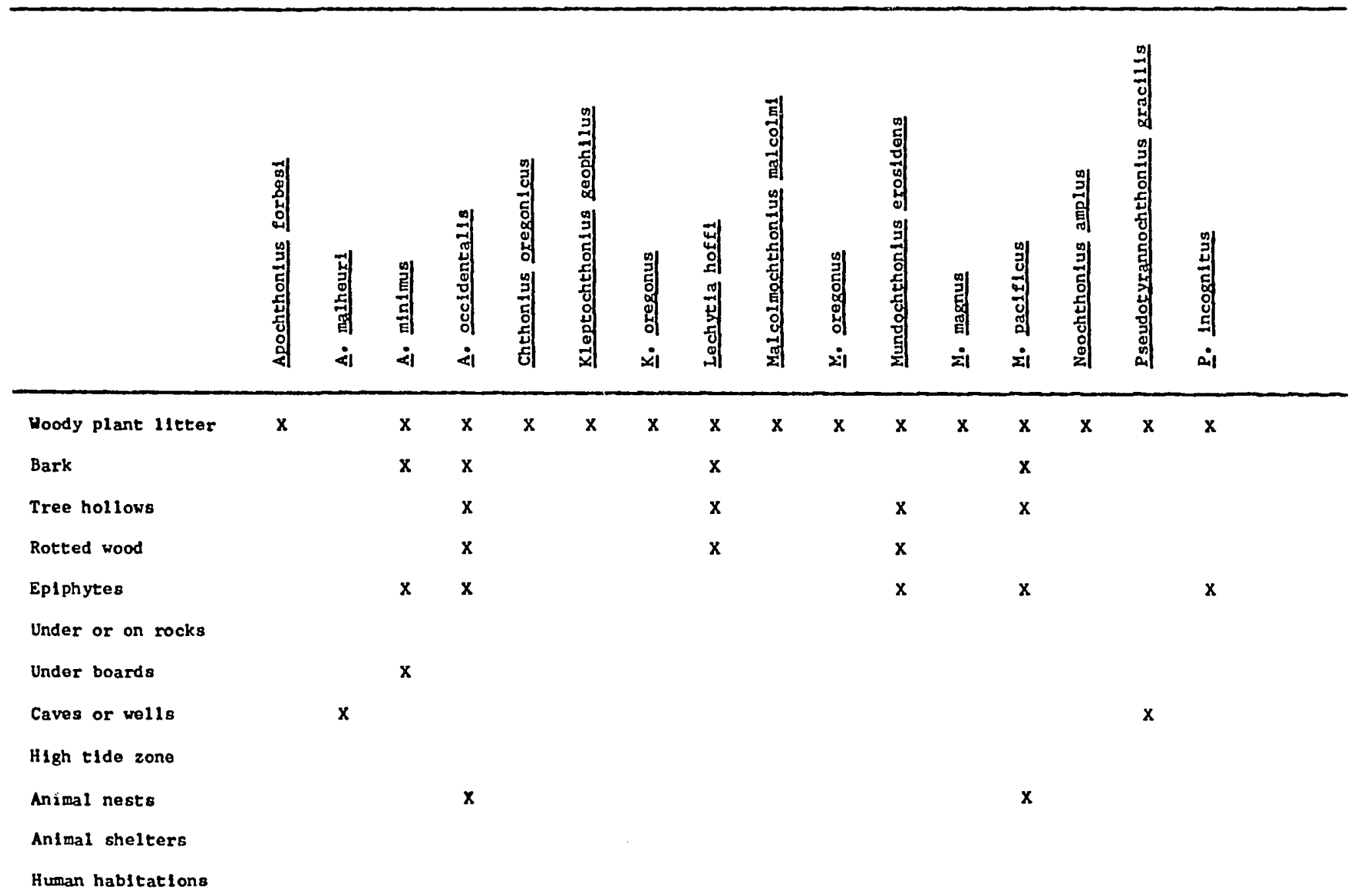


TABLE IV

OREGON HABITATS OF DIPLOSPHYRONID PSELOOSCORPIONS

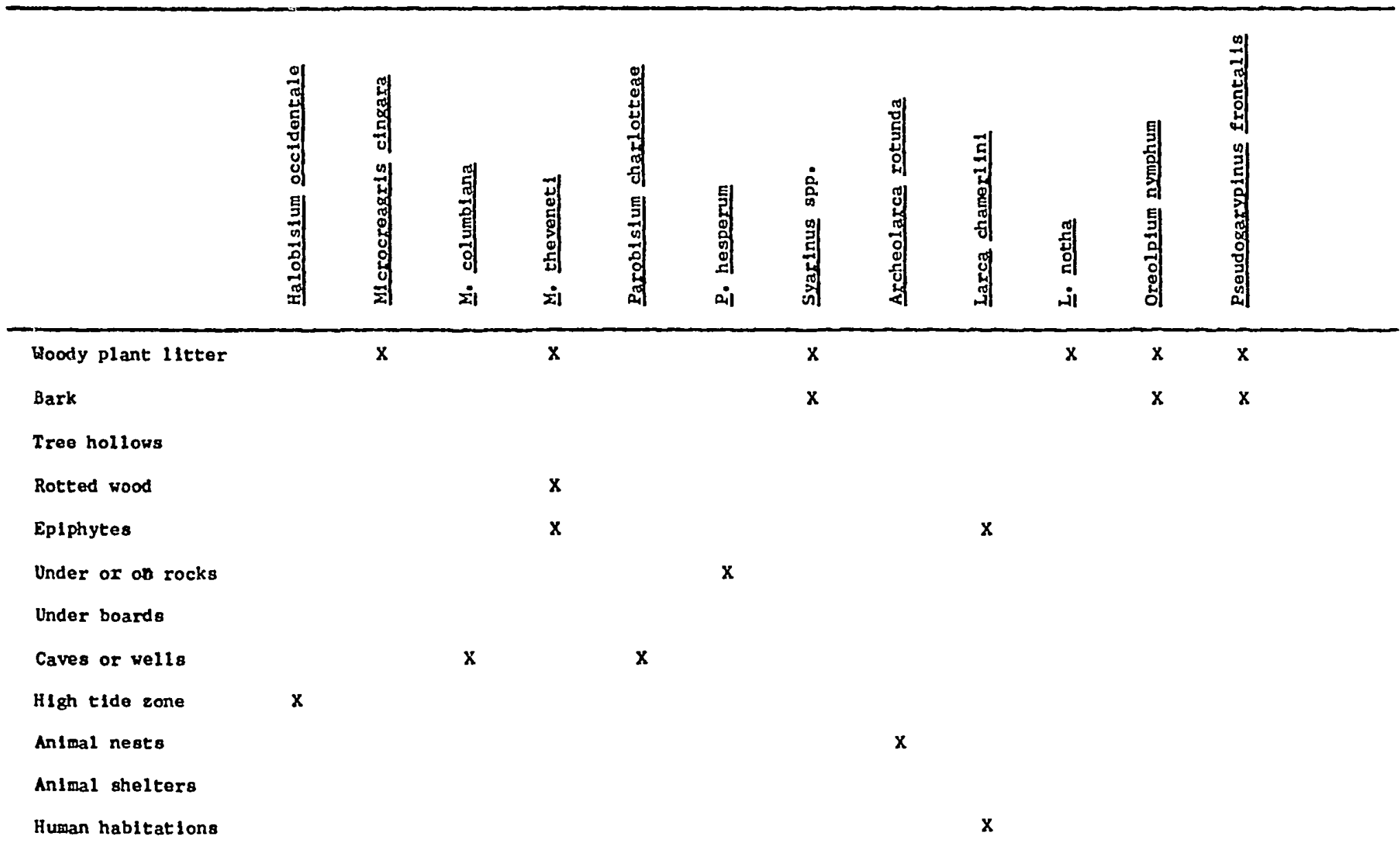


TABLE V

OREGON HABITATS OF MONOSPHYRONID PSEWOSCORPIONS

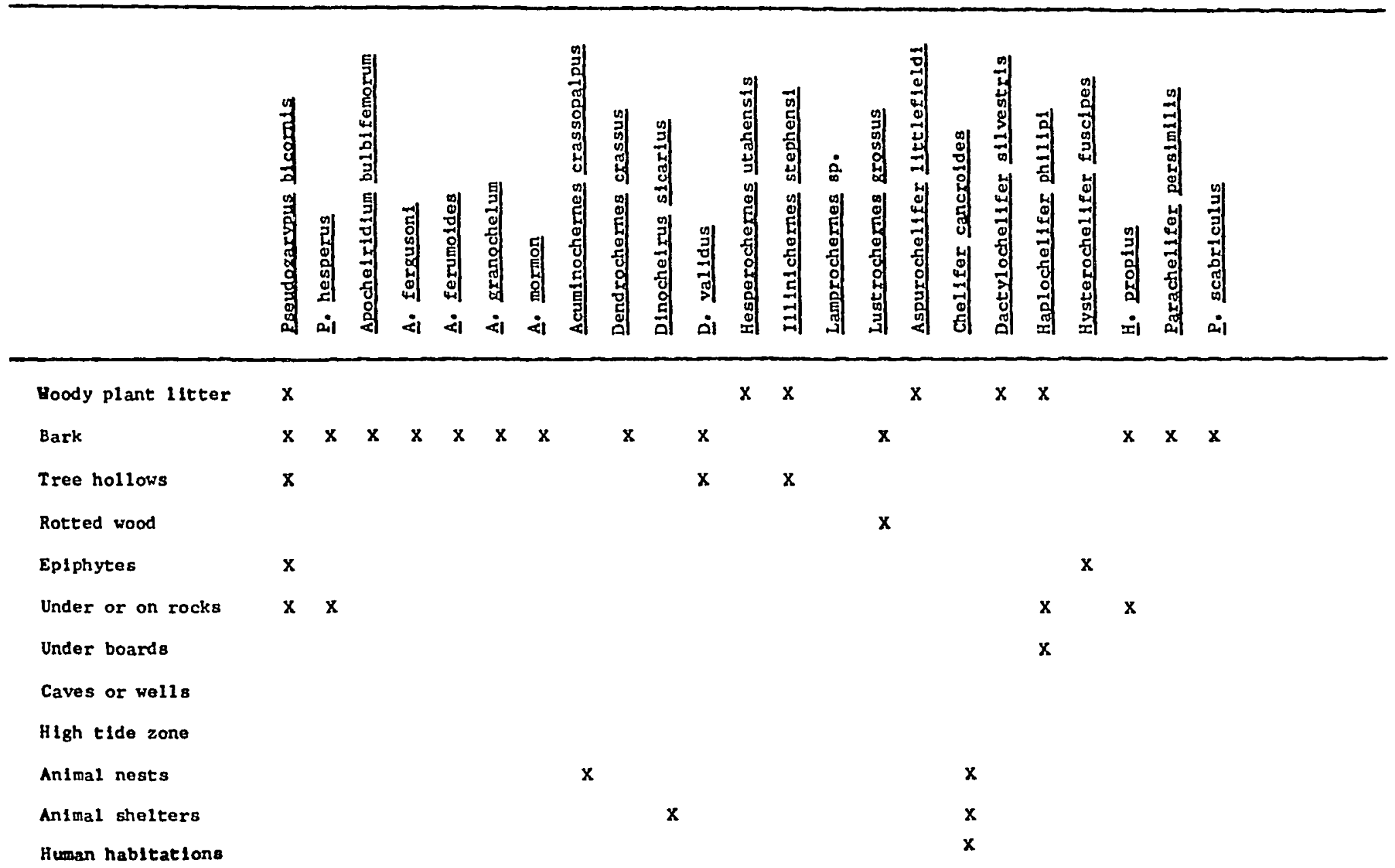


of Intensive sampling, a few generalizations are possible. For example, chthonilds and neobisioids are more common in northwestern Oregon, whlle cheliferids, chernetids and pseudogarypids are more typical of southeastern Oregon.

It is informative to compare these two sections of the state in terms of pseudoscorpion habitat specificity. Superficially, at least, it appears that most species considered in this study exhibit specificity for a habitat type (e.g., bark, leaf litter, litter-dung) rather than for microhabitats provided by particular plant species. However, the diversity of pseudoscorpion species at any given locality appears partially to reflect the diversity of the vegetation at a particular site. For example, in mesic northwestern Oregon where the 1 itter layer is nearly continuous and composed of debris from several plant species, five to seven pseudoscorplon species were often recovered from a sample. In contrast, in semi-arid southeastern Oregon, where the litter layer is in discrete patches, and each patch is composed of debris from only one or two plant species, only one or two pseudoscorpion species were recovered in a sample. At such sites, pseudoscorpion specles appeared to be relatively specific to a particular microhabitat. In fact, at Page Springs (Harney County), I can predict with reasonable accuracy the pseudoscorpion specles by just knowing the microhabltat--e.g., Lechytla hoffi and Haplochelifer philipi in western juniper litter. Hysterochelifer proprius under juniper bark, Pseudogarypus bicornis, Dactylochelifer silvestris and Aspurochelifer littlefieldi in debris of mountain alder and willow, and Apochthonius occidentalis in chokecherry 11 tter. 
Hoff (1959) noted a similar type of specificity exhibited by the peudnscorpion species of New Mexico. Leaf litter species of Iichigan (Nelson 1971) and of the southeastern states (Lawson 1968) appear not to exhibit any particular specificity for a microhabitat, which is the situation with mesic litter species of northwestern Oregon.

The comparison between northwestern and southeastern Oregon can be carried further. A sample from a northwestern site might contain up to 300 pseudoscorpions, but 0-100 were more usual. A sample from a southeastern site might have up to 40 pseudoscorpions, but $0-10$ were more typical. The success rate of recovery from samples from "1ike1y" habitats in northwestern nregon was about $90 \%$, while this rate was about $30 \%$ for southeastern Oregon samples. Naturally, the rate was $h i g h e r$ at resampled sites which explains differences in these percentages and the number of successful collections mentioned under Niethods and Materials.

The following nine categories appear to reflect the known ecological types of the currently identified Cregon pseudoscorpion species.

1. Mesic Litter-Epiphyte-Inhabiting Forms. Mixed deciduousbroad-leaf and coniferous-needle-leaf trees and shrubs occur in dense forests and roodlands in the humid rain forest and semi-rain forest environments of the northern two-thirds of western Cregon. Masses of well-rotted debris accumulate in layers roughly $2-15 \mathrm{~cm}$ deep which cover not only the ground, rocks and logs, but adhere to bark of 
stumps, snags, tree trunks, branches and crotches. Nost of these surfaces support abundant epiphytes, generally mosses and 1 ichens, and often vascular plants such as ferns, huckleberry, salal, and seedlings of western hemlock and Douglas-fir.

Several species of chthoniid and neobisioid pseudoscorpions inhabit both the ground and epiphyte layers. Thus, for practical purposes, it appears that the ground and epiphyte layers are ecologically nearly continuous with each other, enabling certain pseudoscorpions to move between the horizontal and vertical layers. Species which typically inhabit these mesic litter-epiphyte habitats in Oregon are:

Apochthonius minimus. Identified from 15 western Oregon and 1 eastern Oregon county (Niap 7); over 70 collections from roody plant litter (mixed deciduous, sclerophyllous, coniferous), 1 from moss, 1 from bark (pine stump), 1 from under board; elevations 0-1675 m.

Apochthonius occidentalis. From all 18 western Oregon and from 2 eastern Oregon counties (Map 8); over 150 collections from woody plant litter (mixed deciduous, sclerophyllous, coniferous), 3 from mosses-1ichens (forest floor, rock surfaces, log), 3 from bark (1iving tree, drift log), 2 from we11-rotted wood (Sitka spruce stump, rotted log), 1 from tree hollow debris (bigleaf maple), 2 from packrat nest debris (in old shed, on forest floor); elevations $0-1700 \mathrm{~m}$.

Chthonius oregonicus. From 1 southwestern Oregon county (liap 
9); 1 collection from coniferous-deciduous leaf-1itter; elevation near $0 \mathrm{~m}$.

Microcreagris spp. Species of this genus are represented in numerous western Oregon collections from these habitats, but specimens have not been identified to species due to complex systematic problems. Two leaf litter species, $\underline{M}$. thevenet (Banks 1895, 1900) and 쓰 cingara (Chamberlin 1930), were reported by other workers.

Mundochthonius erosidens. From 5 western Oregon counties (Map 11); 10 collections from woody plant litter (mixed deciduous, sclerophyllous, coniferous), 4 from tree hollows, 2 from rotted wood (stump, snag); elevations $60-2285 \mathrm{~m}$. Mundochthonius pacificus. From 6 western Oregon counties (Map 12); 5 collections from woody plant litter (Douglas-fir, California laure1), 3 from mosses-1ichens, 3 from tree hollows, 2 from bark (tree, snag), 1 from shrew's nest; elevations $0-1000 \mathrm{~m}$.

Parobisium spp. Species of this genus are represented in numerous western Oregon collections, but specimens have not been Identified to species due to complex systematic problems. Parobisium hesperum was reported by Chamberlin (1930) from rubble beneath a log above high tide at Cannon Beach (Map 5); it is probable that many of the western Oregon specimens wili be assignable to this species.

Pseudotyrannochthonius incognitus. From 16 western Oregon counties (Nap 14); over 100 collections from woody plant 
and fern litter (mostly deciduous, coniferous), at least 15 from mosses-11chens (forest floor, rock surfaces, logs, tree surfaces), and 5 from rotted wood; elevation 0-1220 m.

2. Semi-Xeric Litter-Inhabiting Forms. Widely diverse forest, woodland, and grass-shrub communities occur in southwestern, northeastern and southeastern Oregon, all characterized by basically dry to seml-dry tree or shrub litter, sometimes less than $1-2 \mathrm{~cm}$ deep. Although the litter layer is nearly continuous in some forests, in other areas, it is in discrete patches due to widely scattered trees or shrubs. A pseudoscorpion species inhabiting these discrete patches appears to exhlbit greater specificity for the litter of one or two plant species than it does in an area where the litter is continuous.

Species typical of semi-xeric litter habitats in Oregon are Apochthonius forbesi. From I eastern Oregon county (Map 7); 1 collection from mossy-leaf litter (mountain spray) in Charcoal Cave No. 1 Sink; elevation $1385 \mathrm{~m}$.

Aspurochelifer littlefieldi. From 3 southern Oregon counties (Map 26); 6 collections from woody plant litter (mountain alder, Oregon ash); elevations 360-1300 m。

Dactylochelifer silvestris. From 3 eastern Oregon counties

(Map 27); 5 collections from woody plant littex (green manzanita, willow, ponderosa pine, big sagebrush); elevation $1185-1375 \mathrm{~m}$.

Haplochelifer philipi. From 10 southern Oregon counties (Map 
27); 39 collections from woody plant litter (oak, madrone, manzanita, juniper, ponderosa pine), 2 from under rocks,

1 from under board; elevations 0-1465 m.

Ilesperochernes utahensis. Fron I southeastern Oregon county

(Map 24); 2 collections from woody plant litter (mountain spray, big sagebrush); elevations 1220-1700 m.

Fleptochthonius geophilis. From 1 southwestern Oregon County

(Map 9); 1 collection from woody plant litter (red alder);

elevation near $0 \mathrm{~m}$.

Kleptochthonius oregonus. From 4 southwestern Oregon counties (Map 9); 33 collections from woody plant litter (deciduous, coniferous, sclerophyllous); elevations 120-1460 m.

Larca notha. From 1 southeastern Oregon county (lap 16);

1 collection from roody plant litter (mountain alder); clevation $1220 \mathrm{~m}$.

Malcolmochthonius malcolmi. From 1 southwestern Oregon county (Nap 10); 9 collections from woody plant litter (manzanita, live oak, oak, madrone, tan oak, sugar pine, knobcone pine, Sitka spruce); elevations $60-915 \mathrm{~m}$.

Malcolmochthonius oregonus. From 1 southwestern Oregon county (Map 10); 1 collection from woody plant 1 itter (tan oak and Douglas-tir); slevation $250 \mathrm{~m}$.

Iundochthonius magnus. From 2 southestern Gregon counties

(Map 11); from 13 collections from woody plant litter (1ive oak, tan oak, bioleaf maple, red alder, bourlas-fir, western white pine); elevations $0-1220 \mathrm{~m}$. 
Neochthonius amplus. From 6 western Oregon counties (Map 13); 12 collections from woody plant 1 itter (Douglas-fir, bigleaf maple, oak, 1ive oak, madrone, manzanita); elevations $0.450 \mathrm{~m}$.

Pseudotyrannochthontus gracilis. From 2 southwestern Oregon counties (Map 14); 1 collection from woody plant litter (Douglas-fir), 1 from lower crawlway in Oregon Cave; elevations $0-1220 \mathrm{~m}$.

3. Sem1-Xeric Litter and Bark-Inhabiting Forms. These pseudoscorplons occur in bark and in the semi-xeric to dry litter discussed in the last category. Bark of certain trees (e.g•, madrone, firs, pines, spruces, Douglas-fir, juniper) tends to exfoliate and accumulate at the base of the trunk; pseudoscorpions commonly inhabit this debris. Certain species (e.g., Pseudogarypus bicornis) inhabit semixeric litter and bark in mesic areas and the more mesic leaf litter

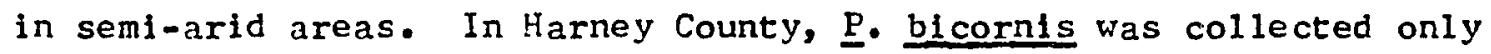
from litter removed from tree crotches of willow and mountain alder but not from western juniper, even at the same localities (Page Springs and Big Indian Creek on Steens Mountain). In western Oregon, $\underline{P}$. bicornis was collected from 1 itter and bark of a wide variety of trees and thus is assigned to this category.

Species which typically inhabit semi-xeric litter and bark habitats in Oregon ares

Lechytia hoffi. From 5 western Oregon and 2 eastern Oregon counties (Map 10); 11 collections from bark ( 1 iving trees, 
stumps, logs), 6 from tree hollows (Douglas-fir, red alder, oak, madrone), 2 from rotted wood (stump, snag), 6 from Iitter of woody plants (juniper, ponderosa pine, madrone, manzanita), 2 from harvester ant debris; elevations 150$1525 \mathrm{~m}$.

Hysterochelifer fuscipes. From 1 western Oregon county (Map 28); 1 collection from under bark ( $10 g), 1$ from moss (tree), 1 from "sweeping"; elevation near $0 \mathrm{~m}$. Pseudogarypinus frontalis. From 2 southwestern Oregon counties (Map 17); 4 collections from woody plant litter (sugar pine, Jeffrey pine, Callfornia black oak, canyon live oak), 2 from bark of Iiving trees (Douglas-fir, madrone); elevations $150-1465 \mathrm{~m} \cdot$

Pseudogarypus blcornis. From 8 counties in southern third of Oregon (Map 18); 24 collections from woody plant 1itter (declduous, coniferous), 6 from bark of living trees (coniferous), 4 from tree hollows (Douglas-fir, grand fir, ponderosa pine, madrone), 5 from mosses-1ichens (surface of rocks, tree trunks), 1 from under rock; elevations 3052075 m。

4. Bark-Inhabiting Forms. Bark of living trees provides three potential zones for pseudoscorpion habitation which I will term epicortical, cortical and subcortical after Chamberlin's (1952) use of "subcortical" for species of Parachelifer.

The epicortical zone (outer surface), if inhabited by 
pseudoscorpions, is typlcally covered with epiphytes. Generally chthonilds and neobisiolds were collected from this zone and not

\section{true bark specles.}

The cortical zone (spaces between bark scales) develops more or less as a tree ages, depending upon its condition and species and the climatic conditions (e.8., temperature, humidity)。 Young trees, with their rather solid bark, apparently lack suitable crevlces for pseudoscorpions or their prey. In contrast, old Douglas-firs and western hemlocks with large diameters (dbh $1.2-2.5 \mathrm{~m}$ ) contain numerous crevices between the well-rotted, thin (1-2 mm) bark layers. These spaces are inhabited by Pseudogarypus hesperus and Oreolpium nymphum. Several species occur between the slightly thicker, more rigid scales

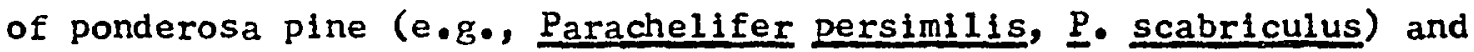
of sugar pine, Sitka and Engelmann spruces (e.g॰, Apocheiridium spp.). H. proprius inhabits bark and branches of western juniper (Figs. 10, 11) and is easily seen in the tiny moist spaces where the exfoliating bark shreds away from the firmly attached bark. Although these examples pertain to coniferous trees, pseudoscorpions typically live in the bark of non-coniferous trees and shrubs also. By far the greater number of the bark-inhabiting specimens was obtained by Berlese extraction rather than by visual inspection of bark in the fleld. The latter method was relatively unsuccessful except for juniper bark.

The subcortical zone (spaces between bark and wood) develops as cambium tissue dies and the bark and wood separate. Thus, pseudoscorplons of this zone are more prevalent in dying trees, snags or 
logs. Such is the case with Dendrochernes crassus in Oregon, and possibly $\underline{P}$. persimilis, both species collected by Hoff (1959) from dead trees or logs in New Mexico. In Oregon, true bark species appear more common in semi-xeric areas, while litter-epiphyteinhabiting forms (chthonilds and neobisiolds) appear more typical of the very humid areas.

Several species 1 isted below are known from only one or two Oregon collections. They are included, efther because the specles is corticolous (or subcorticolous) throughout most of its distributional area, or the genus to which it belongs is bark-inhabiting (e.g., Apocheirldium). In fact, specimens of species such as Oreolpium nymphum, Hysterochelifer proprius (Fig. 11) and Apocheirdium spp. (Fig. 7) exhibit flattened bodies, relatively short legs, and flattened chelae which enable them to move between bark flakes. Species typical of bark habitats in Oregon ares

Apocheiridium bulbifemorum. From 1 southwestern Oregon county (Map 20); 1 collection from bark of 1 iving trees (sugar pine); elevation $800 \mathrm{~m}$.

Apochelridium ferguson1. From 2 eastern Oregon counties (Map 20); 3 collections from bark of living trees (western juniper); elevations $915-1220 \mathrm{~m}$.

Apocheiridium ferumoldes. From 4 western Oregon counties (Map 20); 6 collections from bark of living trees (Sitka spruce, Douglas-fir, western red cedar); elevation near $0 \mathrm{~m}$. Apocheiridium granochelum. From 2 western Oregon counties (Map 21); 3 collections from bark of living trees (oak, 
Oregon ash); elevation near $0 \mathrm{~m}$.

Apocheiridium mormon. From 1 western Oregon county (Map 21);

1 collection from bark of 1 iving tree (oak), 1 from old fence post; elevation near $0 \mathrm{~m}$.

Dendrochernes crassus. From 4 western Oregon and 3 eastern

Oregon counties (Map 22); 4 collections from bark of snags (ponderosa pine, Douglas-fir), 1 from bark of $10 g$ (ponderosa pine); elevations 150-1370 m.

Dinocheirus validus. From 5 western Oregon and 2 eastern Oregon Counties (Map 23); 5 collections from tree hollows (white fir, grand fir, Oregon white oak), 3 from bark of living trees (lodgepole pine, cottonwood), 1 phoretic on fly; elevations $0-? 1000 \mathrm{~m}$.

Hysterochelifer proprius. From 1 western Oregon and 8 eastern Oregon counties (Map 28); 10 collections from bark of living western juniper trees, 1 from bark of living ponderosa pine tree, 4 from ponderosa pine (source unknown), 1 from rock surface, 2 from "beating" (birch, pine); elevations 0-1525 m.

Lustrochernes grossus. From 3 western and 1 eastern Oregon counties (Map 25); 3 collections from bark (rotted log, pine stump, Douglas-fir stump), 2 phoretic on cerambycid beetles; elevations $0-1300 \mathrm{~m}$.

Oreolpium nymphum. From 5 western Oregon counties (Map 17); 10 collections from bark of living trees (Douglas-fir, western hemlock, sugar pine, ponderosa pine), 1 from woody plant litter (Douglas-fir and maple); elevations 305-1675 m. 
Parachelifer persimllis. From 1 western Oregon and 5 eastern Oregon counties (Map 29); 4 collections from "bark", 3 from bark of 1 iving trees (ponderosa pine), 1 from $\log$ (ponderosa pine), 5 phoretic on cerambycid beetles; elevations $0-2150 \mathrm{~m}$ 。

Parachelifer scabriculus. From 4 western Oregon counties (Map 29); 2 collections from bark of living trees (sugar pine, Douglas-fir), 1 from bark of snag (conlfer); elevations $150-1525 \mathrm{~m}$.

Pseudogarypus hesperus. From 6 western Oregon and 2 eastern Oregon counties (Map 19); 19 collectlons from bark of 1 iving trees (Douglas-fir, mountain and western hemlock, Engelmann spruce, Pacific silver fir, western red cedar), 1 from under rock, 1 from outhouse; elevations $0-1525 \mathrm{~m}$.

\section{Tree Hollow-Inhabiting Forms. Hollows of 11 ving trees} nearly always contain rotted wood, unless recently flooded. Less often they contain soil and mammal, bird or insect debris. More rarely, they contain leaf litter and debris of the forest floor which has washed in. Regardless of the origin of the debris or the size of the hollow, these cavities provide suitable conditions for a wide varlety of pseudoscorpions and their prey.

Several types of pseudoscorplons are found in tree hollows. Certain chthonilds, which typically occur in other habltats, are frequently present in the damp, rapidly-decomposing wood of hollows in red alder (e.g. Apochthonius occidentalis). Bark-inhabiting forms 
are in hollows, suggesting either migration between cortical and subcortical spaces and the hollows, or a mixed sample. Phoretic "hosts" may carry pseudoscorpions such as Dinocheirus validus and Acuminochernes crassopalpus into hollows. Illinichernes stephensi appears to be a "true" cavity-dweller. It is common in the decomposing wood and debris of the walls, floor and cellings of hollows of both softwoods and hardwoods, especially in old bigleaf maples.

A typical tree hollow-inhabiting pseudoscorpion from Oregon is: Illinichernes stephensi. From 8 western Oregon counties (Map 24); 28 collections from tree hollows ( 14 bigleaf maple, 3 tan oak, 3 grand fir, 3 California laurel, 2 Oregon white oak, 1 red alder, 1 white fir, 1 madrone), 2 from woody plant litter; elevations 50-1650 m.

6. Animal Nest and Debris-Inhabiting Forms. Animal nests and debris provide habitats for a number of pseudoscorpion species, several of which apparently exhibit a high degree of specifictty for these habitats (Hoff \& Clawson 1952; Weygoldt 1969). However, prior to the present investigation, the only Oregon record reported from bird, small mammal or insect nests was Hoff's (1950) report of Chelifer cancroldes from a swallow's nest from Tillamook County. Only mesic litter-epiphyte-inhabiting forms were recovered from the abandoned bird nests collected during the current study. Although few samples contained material clearly identifiable as rodent debris, C. cancroides and Archeolarca rotunda were extracted from debris of pack rats and Acuminochernes crassopalpus from debris of a California 
ground squirrel. A huge pack rat nest in an incense cedar tree contained litter-inhabiting chthonilds, as did a shrew's nest constructed of mosses. Debris from harvester ant nests in Harney and Deschutes Counties contained Lechytia hoffi, otherwise collected in Oregon from semi-xeric 1itter, bark and rotted wood. It is evident from this data that the pseudoscorpion fauna associated with animal nest debris is virtually unknown for Oregon.

Although insufficient Oregon collections exist to justify including the following species in this category, they are so placed from their records from other states. Oregon species which appear to inhabit animal nests and debris ares

Acuminochernes crassopalpus. From 1 northwestern Oregon county (Map 22); 1 collection from tree hollow debris from California ground squirrel "nest"; elevation near $0 \mathrm{~m}$. Archeolarca rotunda. From 1 eastern Oregon county (Map 16); 1 collection from debris of pack rat (Unnamed Cave, Arnold Lavatube System); elevation $1100 \mathrm{~m}$.

7. Human and Domestic Animal She1ter-Inhabiting Forms. Pseudoscorpions are occasionally seen which are not surrounded by 11tter or debris but instead are in or near human dwellings, under boards or attached to insects. Chelifer cancroides apparently has migrated all over the world with humans and appears to be the only Oregon species typically encountered in or near homes. Other species collected near houses in Oregon are accidentals. For example, Haplochelifer phlilpl was collected from under a board in Klamath 
County and Hysterochelifer fuscipes from mosses growing on an ornamental tree in Berton County, but both are typically associated with native vegetation throughout the ir ranges (see species accounts).

Pseudoscorpions flourish world-wide in the litter-dung layers of domestic animal shelters. Chelifer cancroides and Cheiridium museorum (Leach) are common around homes and farms in Europe, and both are nearly cosmopolitan in distribution (Beier 1932b; Weygoldt 1969). Collidge (1908) listed $\underline{c}$. cancroides as wide-spread and common throughout Europe and the United States, but $\underline{C}$. museorum was only recently reported from North America (Muchmore 1972a). Dinocheirus horrlcus Nelson and Manley occurs in barns In Michigan (Nelson 1975) and D. sicarlus in barns in Califomia (Chamberlin 1952). Samples of debris from domestic animal shelters in Oregon contained both $\underline{c}$. cancroides and D. sicarius, occasionally together. Generally, $\underline{\text {. }}$ cancroides was recovered from somewhat drier materials (hay, grain debris) while D. sicarius was taken from the damper, dung-coated bedding straw. Larca chamberlini was collected on and near mosquitoes in old buildings and Lamprochernes sp. was phoretic on a housefly; both species are included tentatively in this category for lack of other habitat data.

Oregon species associated with human and domestic animal shelters ares

Chelifer cancroides. From 13 Oregon countles (Map 26); 10 collections from inside and 4 from outside human dwellings, 8 from 1 itter-dung layer in barns and sheds, 1 from Neotoma sp. debris in old shed, I from swallow's nest; elevation 
$0-1250 \mathrm{~m}$.

Dinocheirus sicarius. From 9 western Oregon counties (Map 23); 13 collections from litter-dung layer of cow, horse, sheep and pig barns and sheds, 4 from litter of chicken houses; elevation $0-610 \mathrm{~m}$.

Lamprochernes sp. From 1 western Oregon county (Map 25); 1 collection from housefly; elevation?.

Larca chamberlini. From 2 northwestern Oregon counties (Map 16); 3 collections on or in association with mosquitoes in old buildings, I from moss festoons on Sitka spruce tree; elevation $0.220 \mathrm{~m}$.

8. Subterranean-Inhabiting Forms. According to certain views, caves are cavities large enough for human exploration which exist in whole networks of underground cracks and crevices (Barr 1968; Howarth 1973). These networks 1 ie just beneath the 1itter layer and may reach considerable depths in 1 imestone areas such as in Josephine County where Oregon Cave is located. A specialized fauna may inhabit such a network and come in contact with humans in caves, wells and mine shafts. Approximately one-sixth of the nearly 2000 described species and subspecies of pseudoscorpions are reported from caves and many exhibit morphological specializations, such as loss of phoroceptors, reduction of pigment and/or thinning of cuticle, attenuation of appendages and giantism or dwarfism (Chamberlin \& Malcolm 1960; Benedict \& Malcolm 1973; Muchmore 1976).

Of the 206 caves reported from Oregon (Larson \& Larson 1976; 
Larson 1977), pseudoscorplons are known from only four caves. There are several reasons for this paucity of specimens from caves of Oregon. Cave forms may not have evolved due to the lack of preadapted ancestors, insufficient time lapse since cave format: on, inadequate barriers between epigean and hypogean habitats, or inhospitable microclimate conditions within a cave. Or, if evolved, cavernicoles may be undiscovered due to the small amount of blospeleological research in Oregon (Senger 1977).

Pseudoscorpions of five species have been collected in caves or deep wells in Oregon. Archeolarca rotunda from Unnamed Cave was probably an accidental cccuring in the cave in association with rodents, and not cave adapted. Pseudotyrannochthonius gracilis, collected both in the lower crawlway in Oregon Cave and from leaf 1itter, might be able to survive in either habltat. If so, it would be a trogloxene or troglophile (Barr 1960). The other three species, Iisted below, seem to exhibit troglobitic tendencies and would be, therefore, troglophiles or troglobites. Interestingly, Microcreagris columbiana, discovered originally in a well in Clatsop County, Oregon (Chamberlin 1962), was later collected in Pillar of Fire Cave, Klickitat County, Washington (Muchmore 1969c).

Species which appear to be restricted to subterranean habitats in Oregon are:

Apochthonius malheuri. From 1 southeastern Oregon county (Map 7); 4 collections of rotted wood chips from Malheur Cave; elevation $1280 \mathrm{~m}$.

Microcreagris columbiana. From 1 northwestern Oregon county 
(Map 5); 1 collection from a vell; elevation near $0 \mathrm{~m}$. Parobisium charlotteae. From 1 eastern Oregon county (Map 5); 1 collection from Redmond Cave; elevation $1100 \mathrm{~m}$.

9. High Iide Zone-Inhabiting Forms. Several pseudoscorpion species occur along coastlines of the world and thus are exposed to sea water (Weygoldt 1969); Halobisium occidentale inhabits this zone along the Pacific coast of North America. In my attempts to obtain specimens of $\underline{H}$ occidentale and other possible littoral species, I collected samples of tideline debris (algae, driftwood, bark) but pseudoscorpions were not recovered. Apochthonius occidentalis, Mundochthonius spp. and Microcreagris spp. occurred in the sandfilled litter from beneath salt-pruned lodgepole pines and Sitka spruce growing on outer dunes. These pseudoscorpion species also inhabit litter of willow and shrubs growing on deflation plains. The species from Oregon which typically inhabits the High Tide Zone is:

Halobisium occidentale. From 2 coastal Oregon counties (Map 15); 2 collections from under boards and debris of Sa1lcornia-saltgrass tidal flats, 1 from teredo-eaten $10 g$ in high intertidal zone, 1 from gribble-eaten wood in slough, 1 from under estuary-water soaked bark of Sitka spruce tree root; elevation near $0 \mathrm{~m}$.

ECOLOGICAL FACTORS

Chelonethologists attempting to explain distribution and habitat preferences of species generally refer to temperature and humidity 
tolerances, the need for adequate crevices and other "factors" (lloff 1959; leygoldt 1969; Nelson 1971). The only experimental data on this subject are Heygoldt's (1969) observations that the European species Neobisium muscorum (Leach) reproduces in culture only at temperatures between $15-18^{\circ} \mathrm{C}$. Hoff (1959) used indirect evidence of temperature and moisture relationships to explain distribution of species of New Mexico. Thus, it appears that so little is actually known about ecological physiology of pseudoscorpions that any attempt to explain why they occur where they do is pure speculation and a subject for future research. 


\section{CONCLUSIONS}

1. Fifty pseudoscorpion species from nine families are now known from Oregon; on 1 y 13 species from three familles were recorded prior to the initiation of the study in 1971.

2. Oregon's pseudoscorpion fauna is still incompletely known, especially east of the Cascade Mountain crest. At least 12 neobisioid species from both eastern and western Oregon are still to be identified by name, as are several species from other superfamilies.

3. Many pseudoscorpion species reported from Oregon are widely distributed over large geographical areas。

4. Known dispersal mechanisms are adequate to explain the broad distributional patterns observed in this study.

5. Nost western Oregon species considered in this study exhibit specificity for a habitat type (e.g., bark, leaf litter, litter-dung) rather than for a microhabitat provided by a particular plant species. Yost pseudoscorpion species in semi-arid southeastern Oregon habitats appear relatively restricted in habltat type selection.

6. Vestern Oregon samples often contained as many as seven species per sample. Eastern Oregon samples of a similar size generally contained only one or two species when pseudoscorpions were even recovered.

7. Data available on seasonal distribution are inadequate to draw conclusions about the occurrence of various life stages. 


\section{LITERATURE CITED}

Baldwin, E. M. 1976. Geology of Oregon, revised edition. Kenall' Hunt Pub1. Co. Dubuque, Iowa.

Banks, N. 1893. New Chernetidae from the United States. Canad. Entomo1. 25:64-67.

Banks, N. 1895. Notes on the Pseudoscorpionida. J. New York Entomol. Soc. 3\&1-13.

Banks, N. 1900. Papers from the Harriman Alaska Expedition. Proc. Washington Acad. Sci. 2:477-486.

Barks. N. 1909. Now Pseudoscorpionida. Canad. Entomol. 41:303-307.

Banks, N. 1910. Pseudoscorpionida. Harriman Alaska Expedition. Ser. of Smithsonian Instit. 8837,45 .

Barr, T. C., Jr. 1960. Ecological classification of cavernicoles. Amer. Mid1. Nat. 64:1-9.

Barr. T. C. 1968. Cave ecology and the evolution of troglobites. Pp. 35-102 in Dobzhansky, T., M. K. Hecht and H. C. Steere, eds., Evolutionary Biology, Vol. 2. Appleton-Century-Crofts. New York.

Beier, M. 1931. Neue Pseudoscorpione der U. O. Neobisilnea. Mitt. Lool. Mus. Ber11n. 17:299-318.

Beler, M. 1932a. Pseudoscorpionidea. I. Subord. Chthonilnea et Neobisinea. Das Tierreich 57:1-258.

Beier, M. 1932b. Pseudoscorpionidea. II. Subord. Cheliferinea. Das Tierrelch 58:1-294.

Befer, M. 1937. Pseudoscorpione aus dem baltischen Bernstein. Festschrift fúr Prof. Dr. Embrik Strand (Riga) 2:302-316.

Beier, M. 1948. Phoresie und Phagophilie bei Pseudoscorpionen. Öst Zool. Zeftschr. 1:441-497.

Benedict, E. H. 1977. False scorplons of the genus Apocheiridium Chamberlin from western North America (Pseudoscorpionida, Cheirldiidae). J. Arachnol. (in press). 
Benedict, E. M. 1978a. A new pseudoscorpion genus Malcolmochthonius n.g., with three new species from the westem United States. Trans. Amer. Micros. Soc. 97:250-255.

Benedict, E. M. 1978b. A new species of Apochthonius Chamberlin from Oregon (Pseudoscorpionida, Chthonlidae). J. Arachnol. (in press).

Benedict, E. M. and D. R. Malco1m. 1970. Some pseudotyrannochthoriline false scorpions from western North America (Chelonethidas Chthonlidae). J. New York Entomol. Soc. 78,38-51.

Benedict, E. M. and D. R. Malcolm. 1973. A new cavernicolous specles of Apochthonius (Chelonethidas Chthonildae) from the western United States with reference to troglobitic tendencies in the genus. Trans. Amer. Micros. Soc. 928620-628.

Benedict, E. M. and D. R. Malcolm. 1974. A new cavernicolous species of Mundochthonius from the eastern United States (Pseudoscorpionida, Chthoniliae). J. Arachnol. 2:1-4.

Benedict, E. M. and D. R. Malcolm. 1977. Some garypoid false scorpions from western North America (Pseudoscorpionidas Garypldae and 01plidae). J. Arachnol. 5:113-132.

Benedict, E. Mo and D. R. Malcolm. 1978a. The family Pseudogarypidae (Pseudoscorpionida) in North America with comments on the genus Neopseudogarypus Morris from Tasmania. J. Arachnol. (in press).

Benedict, E. M. and D. R. Malcolm. 1978b. Pseudoscorplons of the family Cheliferidae from Oregon (Pseudoscorpionida, Chel iferoidea). J. Arachnol. (in press).

Benedict, E. M. and D. R. Malcolm. 1978c. A new species of Illinichernes Hoff (Pseudoscorpionida, Chernetidae) from tree hollows. J. Arachnol. (manuscript).

Benedict, E. M. and D. R. Malcolm. 1978d. The genus Hysterochelifer Chamberlin in western North America. J. Arachnol. (manuscript).

Benedict, E.M., J. E. Palmer and P. L. Barnhart. 1977. Preliminary report on a three year microclimate study of Malheur Cave, a southeast Oregon lavatube. $\mathrm{P}_{\mathrm{P}}$ 3-4 in E. Werner, ed., Proc. 1976 NSS Ann. Conv., West Virginia Speleo. Sur. Morgantown, H. V.

Burges, A. and F. Raw. 1967. So 11 blology. Academic Press. London.

Chamberlin, J. C. 1924a. The Cheiridilnae of North America (Arachnida-Pseudoscorpionida). Pan-Pacific Entomol. 1:32-40. 
Chamberlin, J. C. 1925. Notes on the status of genera in the chelonethid family Chthonidae, together with a description of a new genus and species from New Lealand. Vidensk. Medd. Dansk Naturh. Foren. 81:333-338.

Chamberlin, J. C. 1929a. A synoptic classification of the false scorpions or chela-spinners, with a report on a cosmopolitan collection of the same.--Part I. The Heterosphyronida (Chthonildae) (Arachnida, Chelonethida). Ann. Mag. Nat. Hist. (10):4:50-80.

Chamberlin, J. C. 1929b. On some false scorpions of the suborder Heterosphyronida (Arachnida-Chelonethida). Canas. Entomol. 61:152-155.

Chamberlin, J. C. 1930. A synoptic classification of the false scorpions or chela-spinners with a report on a cosmopolitan collection of the same. Part II. Diplosphyronida. Ann. Mag. Nat. Hist. (10):5,1-48, 585-620.

Chamberlin, J. C. 1931. The arachnid order Chelonethida. Stanford Univ. Publ. Biol. Sci. 7:1-284.

Chamberlin, J. C. 1932. On some false scorpions of the superfamily Cheiridioidea (Arachnida, Chelonethida). Pan-Pacific Entomol. 8:137-144.

Chamberlin, J. C. 1938. New and 1ittle-known Ealse-scorplons from the Pacific and elsewhere. Ann. Mag. Nat. Hist. (11):2:259285.

Chamberlin, J. C. 1952. New and little-known false scorpions (Arachnida, Chelonethida) from Monterey County, California. Bull. Amer. Mus. Nat. Hist. 998263-312.

Chamberlin, J. C. 1962. New and little-known false scorpions, principally from caves, belonging to the families Chthoniidae and Neoblsildae (Arachnida, Chelonethida). Bull. Amer. Mus. Nat. Hist. 123,303-352.

Chamberlin, J. C. and D. R. Malcolm. 1960. The occurrence of false scorpions in caves with special reference to cavernicolous adaptation and to cave species in North American fauna (Arachnida-Chelonethida). Amer. Midl. Nat. 648105-115.

Cloudsley-Thompson, J. L. 1958. Splders, scorplons, centipedes and mites. Pergamon. Iondon.

Collidge, K. R. 1908. A 11st of the North American Pseudoscorpionida. Psyche. 15:108-114. 
Cromack, K., Jr., P. Sollins, R. L. Todd, D. A. Crossley, Jr., W. M. Fender, R. Fogel and A. W. Todd. 1977. Soll microorganism-arthropod interactionsi fungi as major calcium and sodium sources. Pp. 78-84 in W. J. Mattson, ed., The role of arthropods in forest ecosystems. Springer-Verlag. New York.

Crossley, D. A., Jr. 1977. The role of terrestrial saprophagous arthropods in forest soils: current status of concepts. Pp. 49-56 in $1 . \mathrm{J}$. Mattson, ed., The role of arthropods in forest ecosystems. Springer-Verlag. New York.

Di Castri, F. 1970. Les grands problems qui se posent aux ecologistes pour $1^{\prime}$ etude des ecosystemes du sol. Pp. 15-31 in J. Phillipson, ed., Methods of study in soil ecology. Rroc. of Parls Symp. UNESCO and IBP. Paris.

Dicken, S. N. 1973. Oregon geography, the people, the place, and the time. 5th ed. Edward Brothers, Inc. Ann Arbor, Michigan.

Drift, J. van der. 1951. Analysis of the animal community in a beech floor. Meded. Inst. Toegep. Biol. Onderz. Nat. $981-168$.

Drift, J. van der. 1970. Problems in soil ecology requiring most urgent attention. Pp. 295-300 in J. Phillipson, ed., Methods of study in soil ecology. Proc. of Paris Symp. UNESCO and IBP. Paris.

Edwards, C.A., D. E. Reichle, and D. A. Crossley, Jr. 1970. The role of soil invertebrates in turnover of organic matter and nutrients. Pp. 147-172 In D. E. Reichle, ed., Ecological studies I, Analysis of temperate forest ecosystems. Springer-Verlag, New York.

Essig, E. O. 1958. Insects and mites of western North America. Macmillan Co. New York.

Frank1in, J. F. and C. T. Dyrness. 1973. Natural vegetation of Oregon and Washington. USDA Forest Service General Technical Report PNk-8. Portland, Oregon.

Gabbutt, P. D. 1967. Quantitative sampling of the pseudoscorpion Chthonius ischnocheles from beech 1itter. J. Zool. London $1511469-478$.

Gabbutt, P. D. 1970. Sampling problems and the validity of 1 ifehistory analysis of pseudoscorpions. J. Nat. Hist. 481-15.

Gabbutt, P. D. and M. Vachon. 1963. The external morphology and life history of the pseudoscorpion Chthonius ischnocheles (Herman). Proc. Zool. Soc. London 141875-98. 
Gering, R. L. 1956. Arachnidst Splders, pseudoscorpions, scorplons, solpugids. Pp. 50 in A. M. lioodbury, ed., Ecological check 11sts. The Great Salt Lake Desert Series. Univ. of Utah. Dugway, Utah.

Gertsch, W. 1973. The spider family Leptonetidae in North America. J. Arachnol . 1,145-203.

Greeley, R. 1971. Geology of selected lava tubes in the Bend Area, Oregon. Bul1. Oregon Dept. Geol. Min. Ind. 71:1-46.

Gruber, E. H. and E. M. Benedict. 1978. The effects of DDT on nontarget soil organisms in northeastern Oregon. In Final report of envi ronmental monitoring of non-target organisms in the 1974 DDTi'Tussock Moth Control Project in Idaho, Oregon, and liashington. (in press).

Hitchcock, C. I. and A. Cronquist. 1973. Flora of the Pacific Northwest, an illustrated manual. Univ, of Wash. Press. Seattle, Wash.

Hoff, C. C. 1945. New species and records of pseudoscorpions from Arkansas. Trans. Amer. Micros. Soc. 64834-57.

Hoff, C. C. 1947. The species of the pseudoscorpion Chelanops described by Banks. Bull. Harvard Univ. Mus. Comp. Zool. 98:473-550.

Hoff, C. C. 1949. The pseudoscorpions of Illinols. Bull. Illinois Nat. Hist. Sur. 24:413-498.

Hoff, C. C. 1950. Some North American cheliferid pseudoscorpions. Amer. Musc. Novitates 1448:1-18.

Hoff, C. C. 1952. Some heterosphyronid pseudoscorpions from New Mexico. Great Basin Nat. 12839-45.

Hoff, C. C. 1956a. The heterosphyronid pseudoscorpions of New Mexico. Amer. Musc. Novitates 177281-13.

Hoff. C. C. 1956b. Diplosphyronid pseudoscorpions from New Mexico. Amer. Mus. Novitates 1780:1-49.

Hoff, C. C. 1956c. Fseudoscorpions of the family Chernetidae from New Mexico. Amer. Musc. Novitates 1800,1-66.

Hoff, C. C. 1956d. Pseudoscorpions of the family Cheliferidae. Amer. Mus. Novitates 1804:1-36.

Hoff, C. C. 1958. List of pseudoscorpions of North America north of Mexico. Amer. Mus. Novitates 1875:1-50. 
Hoff, C. C. 1959. The ecology and distribution of the pseudoscorpions of North-Central New Mexico. Univ. New Mexico Press. Univ. of New Mexico Publ. in Biol. 8,1-68.

Hoff, C. C. 1961. Pseudoscorpions from Colorado. Bull. Amer. Mus. Nat. Hist. 122, $113-464$.

Hoff. C. C. 1963. Pseudoscorpions from the Black Hills. Amer. Mus. Novitates 2134:1-10.

Hoff, C. C. 1964. The pseudoscorpions of Jamaica. Bull. Instit. of Jamaica. Sct. Ser. 10(3):5-47.

Hoff, C. C. and D. L. Clawson. 1952. Pseudoscorpions from rodent nests. Amer. Mus. Novitates 1585:1-38.

Hoff, C. C. and D. T. Jennings. 1974. Pseudoscorplons phoretic on a spider. Entomol. News 85321-22.

Howarth, F. G. 1973. The cavernicolous fauna of Hawalian lava tubes, I. Introduction. Pacific Insects 158139-151.

Knowlton, G. R. 1972. Some terrestrial arthropods of Curlew Valley. Utah State Univ. Ecol Center. Terrestrial Arthropod Ser. 411-4.

Kuhnelt, 1!. 1961. Soil biology with special reference to the animal kingdom. Rodale Books Inc. Emmaus, Penn.

Kurten, B. 1969. Continental drift and evolution. Pp. 114-123 in J. T. Uilson, ed., 1971. Continents adrift. Readings from Sci. Amer. H. H. Freeman \& Co. San Francisco.

Iarson, C. V. 1977. Bibliography of Oregon Speleology. Bull. Oregon Speleo. Sur. 6:1-95.

Larson, C. V. and J. J. Larson. 1976. Caves of Oregon. Bull Oregon Speleo. Sur. 4:1-42。

Lawson, J. E. 1968. Systematic studies of some pseudoscorpions (Arachnidas Pseudoscorpionida) from the southeastern United States. Ph.D. Thesis. Virginia Polytechnic Institute.

Loy, H. G., S. Allan, C. P. Patton and R. D. Plank. 1976. Atlas of Oregon. Untve of Oregon Bks. Eugene, Oregon.

Malcolm, D. R. and J. C. Chamberlin. 1961. The pseudoscorpion genus Kleptochthonius Chamberlin (Chelonethida, Chthonildae). Amer. Mus. Novitates 2063:1-35. 
Nanley, C. V. 1969. A pictorial key and annotated list of Michigan pseudoscorpions (Arachnidas Pseudoscorpionida). Mich. Entomol. 2:2-13.

Mattson, k. J. 1977. ed. The role of Arthropods in forest ecosystems. Proc. in Life Scl. 15th Internat. Cong. Entomol. Washington, D.C. 1976. Springer-Verlag. New York.

McBrayer, J. F. 1977. Contributions of cryptozoa to forest nutrient cycles. Pp. 70-77 in W. J. Mattson, ed., The role of arthropods in forest ecosystems. Springer-Verlag. New York.

Mckee, B. 1972. Cascadia, the geologic evolution of the Pacific Northwest. McGraw-H\$11 Inc. New York.

Muchmore, ‥ B. 1963. Two European arachnids new to the United States. Entomol. News 74:208-210.

Muchmore, h. B. 1967a. Pseudotyrannochthoniine pseudoscorpions from the western United States. Trans. Amer. Microsc. Soc. $86,132-139$.

Muchmore, H. B. 1967b. New cave pseudoscorpions of the genus Apochthonius (Arachnidas Chelonethida). Ohio J. Sci. 67:89-95.

Muchmore, h. B. 1968. Two new species of chthoniid pseudoscorpions from the western United States (Arachnida: Chelonethida: Chthonidae). Pan-Pacific Entomol. 44851-57.

Muchmore, H. B. 1969a. The pseudoscorpion genus Neochthonius Chamberlin (Arachnida, Chelonethida, Chthonilidae) with description of a cavernicolous species. Amer. Midl. Nat. 818387-394.

Muchmore, V. B. 1969b. A population of a European pseudoscorpion established in New York. Entomol. News 80866.

Muchmore, w. B. 1969c. New species and records of cavernicolous pseudoscorplons of the genus Microcreagris (Arachnida, Chelonethida, Neobisildae, Ideobisilnae). Amer. Mus. Novitates 2392:1-21.

Muchmore, K. B. 1971. Phoresy of North and Central American pseudoscorplons. Proc. Rochester Acad. Sci. 12:79-97.

Muchmore, $\because$. B. 1972a. European pseudoscorpions from New England. J. New York Entomol. 80,109-110.

Muchmore, K. B. 1972b. Observations on the classification of some European chernetid pseudoscorpions. Bul1. British Arachnol. Soc. 28111-115. 
Muchmore, H. B. 1973. Ecology of pseudoscorpions, a review. Proc. lst Soil Microcomm. Conf. Syracuse, N. Y. 12l-127.

Muchmore, K. B. 1974a. New cavernicolous species of Kleptochthonius from Virginia and West Virginia (Pseudoscorpionida, Chthonildae). Entomo1. News 85,81-84.

Muchmore, 1. B. 1974b. Clarification of the genera Hesperochernes and Dinocheirus (Pseudoscorpionida, Chernetidce).

$\mathrm{J}$. Arachnol. 2:25-36.

Muchmore, W. B. 1975a. The genus Lechyt1a in the United States (Pseudoscorpionida, Chthoniidae). Southwestern Nat. 20:13-27.

Muchmore, I. B. 1975b. Use of the spermathecae in the taxonomy of chernetid pseudoscorpions. Proc. 6th Int. Arachnol. Cong. Amsterdam IV. 1974:17-20.

Muchmore, I. B. 1976. New species of Apochthonius, mainly from caves in central and eastern United States (Pseudoscorpionida, Chthonidae). Proc. Biol. Soc. Hashington 89:67-80.

Muchmore, I. B. and E. M. Benedlct. 1976. Redescription of Apochthonius moestus (Banks), type of the genus Apochthonius Chamberlin (Pseudoscorpionida, Chthonidae). J. New York Entomol. Soc. 84:67-74.

Muller, A. H. 1960. Lehrbuch der paiaeozooiogie. Jena Gustav Fischer Verlag.

Nelson, S., Jr. 1971. A systematic study of Michigan Chelonethida, and the population structure of Microbisium confusum Hoff in a beech-maple woodlot. Fh.D. Thesis. Michigan State Univ.

Nelson, S., Jr. 1975. A systematic study of Michligan Pseudoscorpionida (Arachnida). Amer. Midl. Nat. 93:257-301.

Palmer, J. E. 1975. Biochemical description of a lava tube lake in southeast Oregon. M.S. Thesis. Portland State Univ.

Peck, M. E. 1961. A manual of higher plants of Oregon. Binfords \& Mort, publishers. Portland, Oregon.

Phillipson, J. 1970. ed. Methods of study in soil ecology. Proc. of Paris Symp. UNESCO and IBP. Paris.

Poulson, T. I. and T. C. Kane. 1977. Ecological diversity and stablity, principles and management. Pp. 18-21 in Nat 1 . Cave Man. Symp. Proc. 1976. Speleobooks. Albuquerque, N.M. 
Ress1, F. and M. Beier. 1958. Zur Okologie, Biologie und Phanologie der heimischen Pseudoskorpione. Zool. Zahrb (Syst.) 86:1-26.

Roewer, C. F. 1940. Cheloneth1 order Pseudoskorpione. Pp. 321-354 in H. G. Bronn. Klassen und Ordnungen des Tierrelchs. Vol. 5.

Savory, T. 1964. Arachnida. Academic Press. London.

Savory, T. 1966. False scorpions. Sci. Amer. 214195-100.

Savory, T. 1968. Hidden 1ives. Sci. Amer. 219:108-114.

Schaller, F. 1968. Soll animals. The Univ. of Michigan Press. Ann Arbor.

Schuster, R.O. 1962. New species of Kewochthonius Chamberlin from California (Arachnida: Chelonethida). Proc. Blol. Soc. lashington. 75,223-226.

Schuster, R. C. 1966a. A new species of Allochthonius from the Paclfic Northwest of North America. Pan-Pacific Entomol. 428172-175.

Schuster, R. O. 1966b. New species of Apochthonius from western North America. Pan-Pacific Entomol. 421178-183.

Schuster, R. O. 1968. The identity of Roncus pacificus Banks (Arachnida Chelonethida). Pan-Pacific Entomol. 448137-139.

Senger, C. M. 1977. Blological research in Pacific Northwest cavess opportunties and difficulties. Pp. 6-7 in Program of 1977 hestern Speleo-educational Seminar, Vancouver, hashington. Oregon Grotto Press. Vancouver. (abstract).

Shear, k. A. 1973. The milliped family Rhiscosomididae (Diplopodat Chordeumidas Striarioidea). Psyche 80,189-203.

Shear. H. A. 1974. The milliped genus Bollmanella (Diplopoda, Chordeumida, Conotylidae). Psyche 811134-146.

Shear, H. A. 1975. The opilionid genera Sabacon and Tomicomerus in America (Opiliones, Trogulidae, Ischyropsalidae). J. Arachnol. $3: 5-29$.

Shulte, G. 1976. Litoralzonierung von pseudoskorpionen an der Norda-amerikanischen Pazifikkuste (Arachnida, Pseudoscorpiones, Neobisidae, Garypidae). Entomol. Germ. 3,119-124.

Udvardy, M. D. F. 1969. Dynamic zoogeography with special reference to 1 and animals. Van Nostrand Reinhold Co. New York. 
Wallwork, J. A. 1970. Ecology of soll animals. McGraw-H111, London.

Vallwork, J. A. 1976. The distribution and diversity of soll fauna. Academic Press, London.

Hebb. D. P. 1977. Regulation of deciduous forest 1itter decomposition by soll arthropod feces. Pp. 57-69 in V. J. Mattson, ed., The role of arthropods in forest ecosystems. Springer-Verlag. New York.

Westgarth, W. C. 1975. Status report of study on effects of DDT on certain forest arthropods, Pp. 61-62 in Benson, W. W., Wo C. Westgarth, D. O. Provost, and P. R. Canutt, eds., Interim report of envi ronmental monitoring of non-target organisms in the 1974 DDT,'Tussock Moth Control Project in Idaho, Oregon, and Washington. Feb. 1975. Interagency Monitoring Committee。 Portland, Oregon.

Heygoldt. P. 1969. The biology of pseudoscorplons. Harvard Books in Biology, No. 6. Harvard Univ. Press. Cambridge, Mass. 


\section{APPENDIX I}

MAP OF OREGON COUNTIES

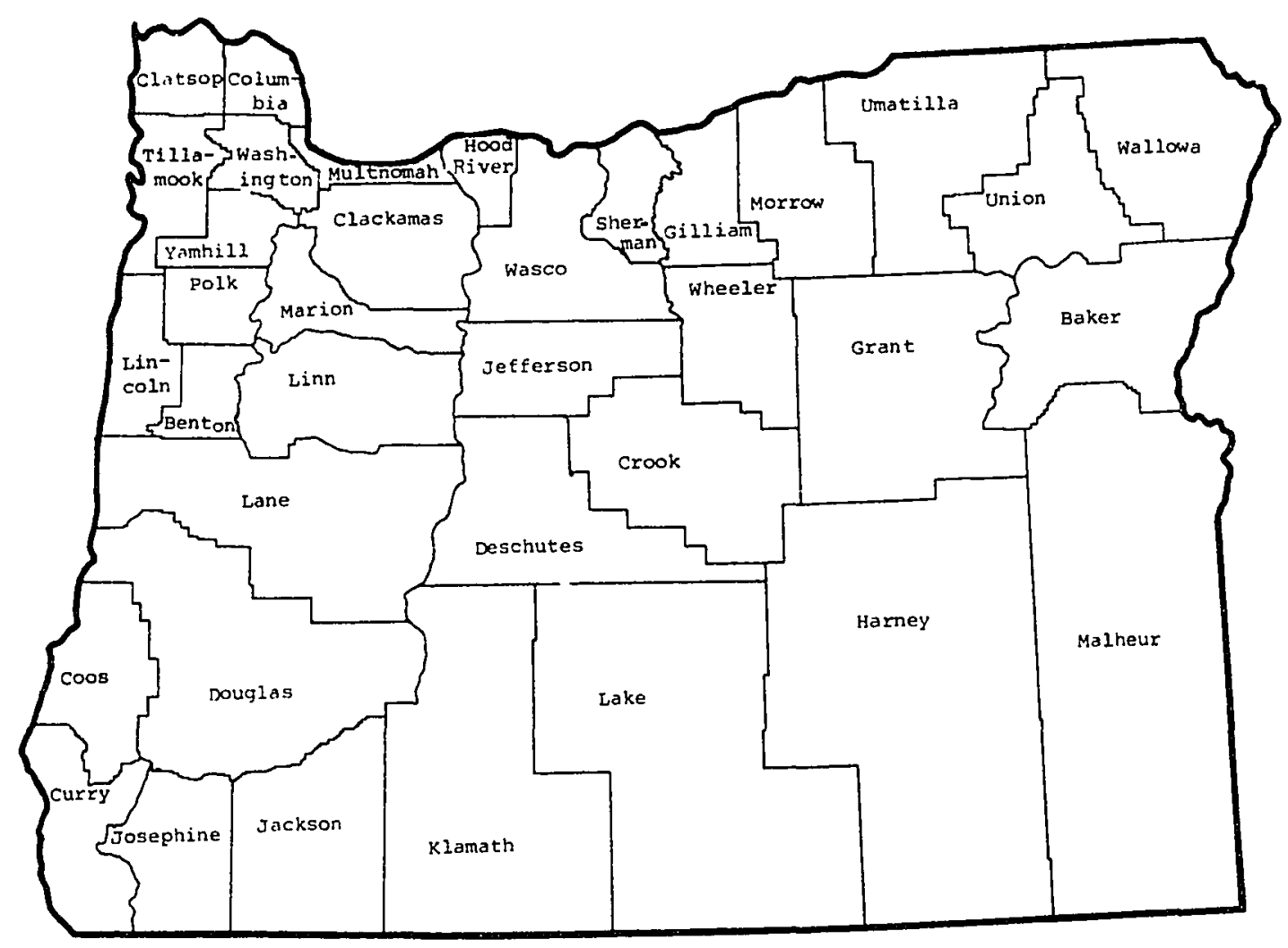




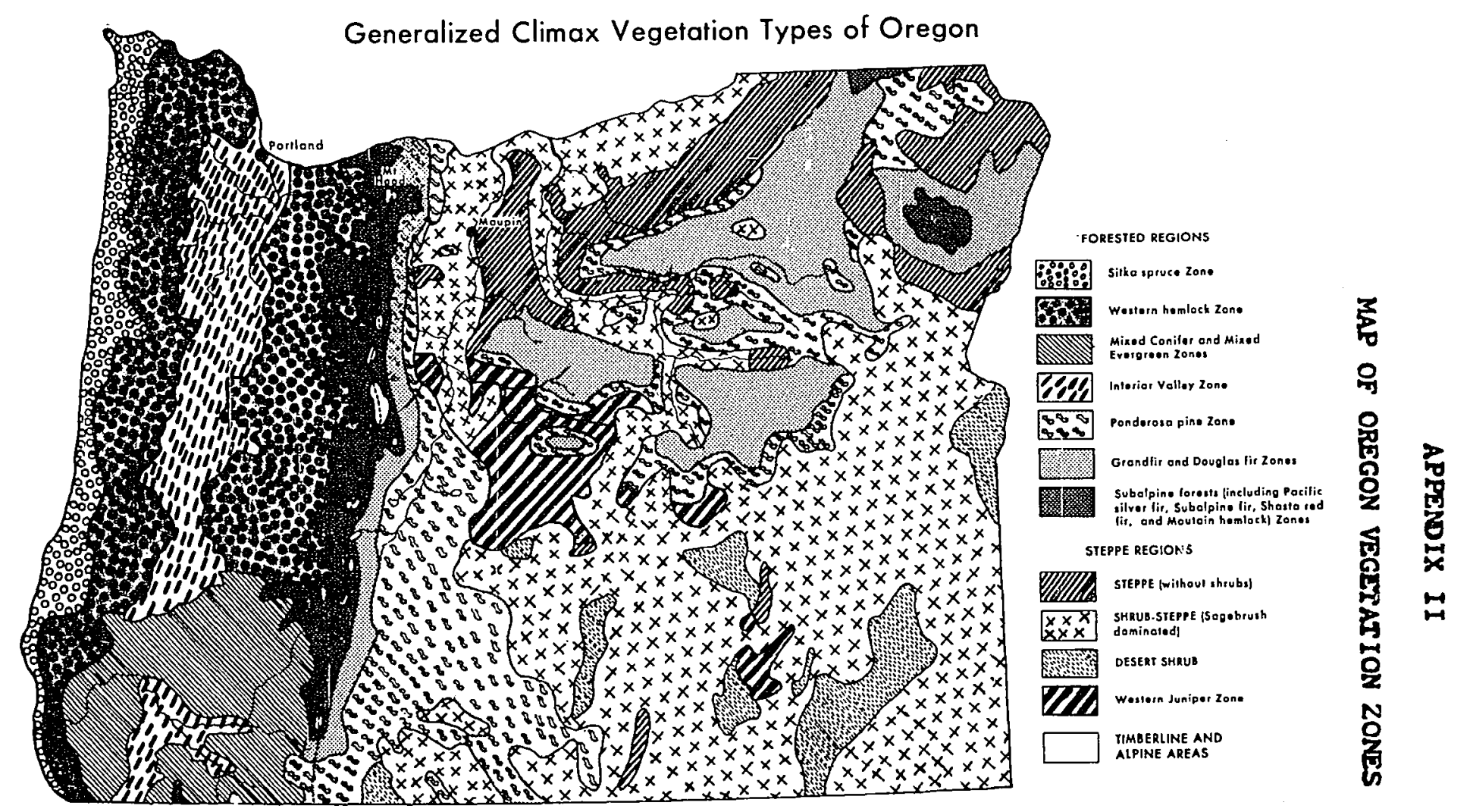

Sourcei Frankiln, J. F. and C. T. Dyrness。 1969. Vegetation of Oregon and Hashlngton. USDA Forest Service Research Paper, PN-80,38-39. Redrawn by L. W. Price. Blogeography fleld gulde to Caseade Hountains, transect along U. S. Highway in Oregon。 Occasional Papers in Geography. Portland State Univo $1,1-36$ 。 
GENERAIILED DIAGRAM OF A DIPLOSPHYRONID PSELDOSCORPION (From Chamberlin 1931)

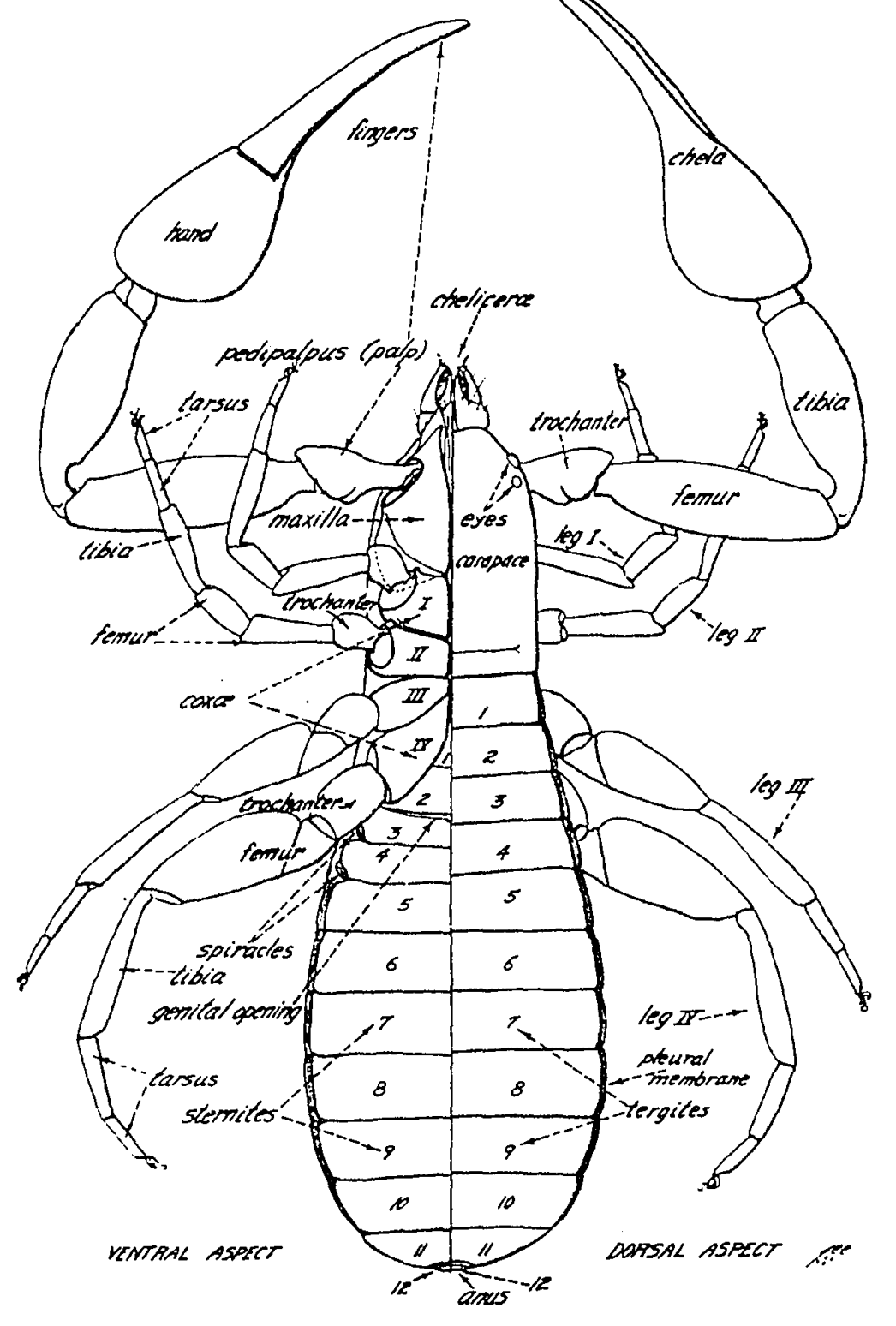




\begin{abstract}
APPENDIX IV
IDENTIFICATION KEY TO OREGON PSEWOSCORPIONS
\end{abstract}

Although only the presently identifled Oregon species and genera are included, this key should be useful for many of the specimens from adjacent states as well as Oregon. The key is modified, in part, fron Hoff 1958, 1959; Lawson 1968; Nelson 1975; Benedict \& Malcolm 1970, 1973, 1978a; Benedict 1977, 1978a. For details of morphological terms, see Chamberlin 1931, Hoff 1949, and Nelson 1975. For generalized view of a pseudoscorpion, see Appendix III. Illustrations in the key are from the following sources: Figs. 1-5, 25-36, 44-47, 51-58, 67 from Chamberlin 1931; Figs. 6, 12-13 from Lalcolm \& Chamberlin 1961; Figs. 7-11 from Benedict \& Malcolm 1970; Figs. 14-15, 18 Benedict \& Malcolm 1973; Fig. 16 from Chamberlin 1929a; Fig. 21 from Chamberlin 1962; Figs. 22, 24 from Benedict 1978a; Figs. 37, 40-43 from Benedict \& Malcolm 1978a; Figs. 38, 48-50 from Benedict 1977; Fig. 39 from Benedict \& Malcolm 1978c; Figs。 48-50 from Benedict 1977; Figs。 61-64, $66-69,71,74-75$ from Chamberlin 1962; Figs. 77-78 from Benedict \& Malco1m 1978d. Fig. 23 was redrawn from Schuster 1968, Fig。 65 from Hoff 1949, and Fig. 63 from Hoff 1956c. The other Elgures are original. 

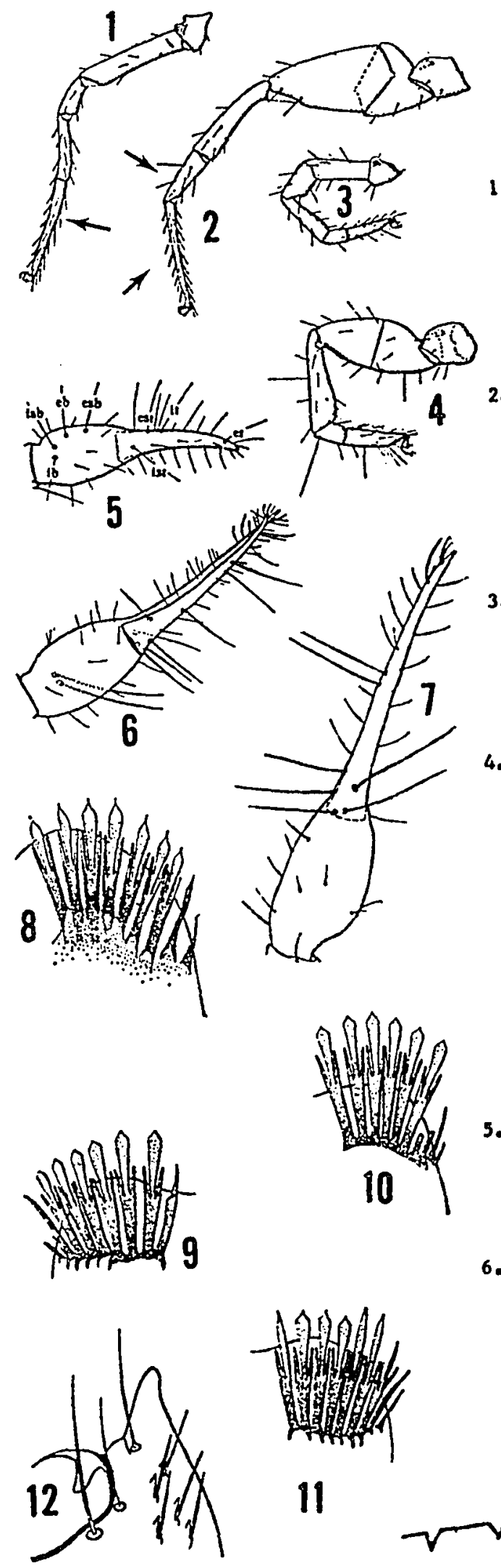

1. Logs I and II with a single tarsal segwent (Fig. I), legs III and IV with 2 tarsal segmente (Fig. 2) (suborder Heterosphyronida, famlly Chthonlidae)..............

Legs, all, with an equal number of segments (F1gs. 3, 4) ........................

Chelal hand with 4 tactlle setae on. dorsum (F1g. 5)......... Lechytia hoffl, P.

Cholal hand elther with a transverse palr of tactile setae on dorsum (F18, 6), or with tact1lo setao absent on dorsum (Elg, 7)....................

3. Chelal hand without a transverse palr of sotae)..... (genus Pseudotyrannochthonius)

Chelal hand with a transverse palr of tact 110 setae...............................

4. Coxal splnes arise individually from a 11 ghtly sclerotlzed or translucent hillock $(F 1 \mathrm{~g}, 8)$; chelal length of male $0.98-1.10 \mathrm{~mm}$, of female 1.12-1.40 mol palpal fenur length of male 0.68-0.79 mbo of temale 0.78-0.98 ...................... E. gracills, p. 34

Coxal splnos arlse individuzliy from a more heavlly sclesotlzed bar, or from contlguous ball-shaped pedestals (Fig. 9-1I), not a translucent hlllock; chelal length of male 0.79-0.94 ma, of female 0.89-1.11 m, femur length of male $0.49-0.66 \mathrm{~mm}$, of female 0.59-0.76 mm....... P. incognitus, p. 36

5. Coxal spines present on coxae, I, acuminate and confined to mesal portion (Fig, 12)..... 6

Coxal splnes absent fros coxae I.............. 10

6. Chelal fingars with marginal teoth well spaced (F1g. 13) distally (genus Kleptochthonlusi K. geophllug cannot bo separated from K. orggenus) ....... K. oregonus, P. 26

Chelal ingers with teath amall and contiguous (F1g. 14) (ganus Apocithonfus)............... 7

11

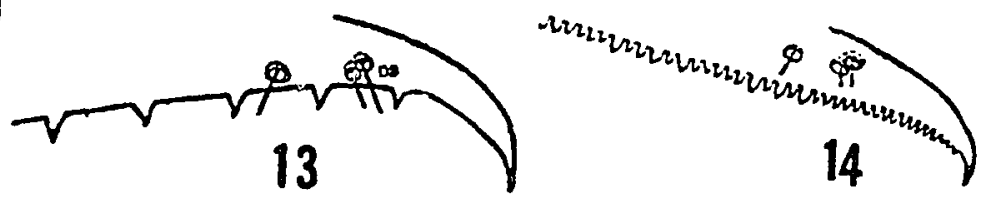



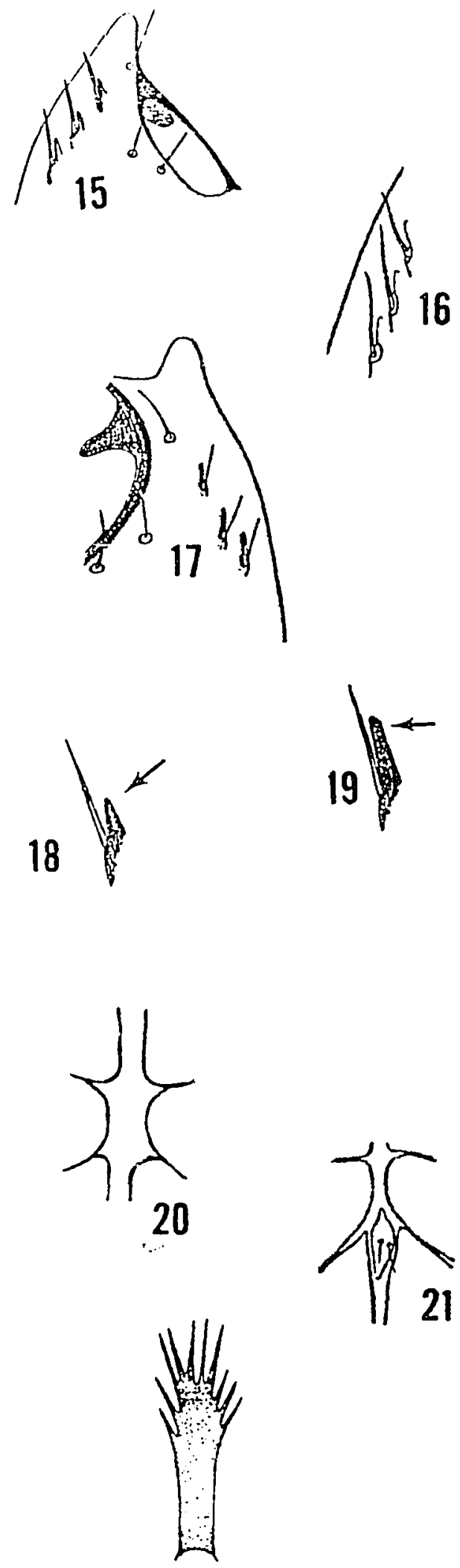

22
7. Coxal splne with a well-developed anterlor spur (Fig. 15)........................... 8

Coxal splne, etther lacklng anterlor spur (F1g. 16) or, at most, with a very tiny anterlor projection (FIg . 17)................. ................... A. occldental1s, P. 21

8. Palpal femur length groater than $0.50 \mathrm{~mm}$, chela length greater than 0.75 man.............

Palpal femur langth les: than 0.45 m, chela length less than 0.70 man anterlor spur of coxal splne highly varlable in length $\left(F I_{g s} .18,19\right) \ldots \ldots \ldots$ A. minlmus, p. 20

9. Carapace with 24 sotaes 1 palr of very veakly-developed ayess femur length of male 0.58-0.69 m (Eemale unknown); chola length of male 0.91-1.05 mas from Malheur Cave...................... A. malheurl, P. 19

Carapace with more than 24 Betaos 2 weak paixs of eyess femux length of male $0.55 \mathrm{~mm}$, of temale $0.53 \mathrm{~mm}$; chela length of male 0.85 son, of female 0.79 min... A. forbest, P. 17

10. Coxal spines on mesal portion of both coxae II and III.......................... 11

Coxal spines on mesal portion of coxae II only................................... 12

11. Chelal fixed EInger with teeth contlguous and blunt.............. Neochthonius amplus, P. 33

Chelal fixed finger with teoth acute and spaced distally.... Chthonlus oregonlcus, P. 23

12. Intercoxal tubercle absent (FIg - 20) between bases on coxae III and IV (genus Malcolmochthonlus) ....................... 13

Intercoxal tubercle present (FIg. 21) betweon bases of coxae III and IV (genus Mundochichonlus) .............................. 14

13. Terglte II with 6 setaes palpal fenur length of male 0.27-0.31 mo of female 0.26-0.33 m....................... M. malcolml, p. 28

Terglte II with 4 setae 3 palpal remur length of male 0.34 (Female untnown)

......................... M. opegonus, p. 29

14. Tergltes IV to VIII, mostly with 8 or 9 setae and coxal spine nearly 5 tlmes longer than basal width (F/B. 22)......... M. magnus, P. 32

Tergltes IV to VIII, each lese than 8 (normally with 6) sotae and coxal spine length less than 5 timos basdl width.......... Is 


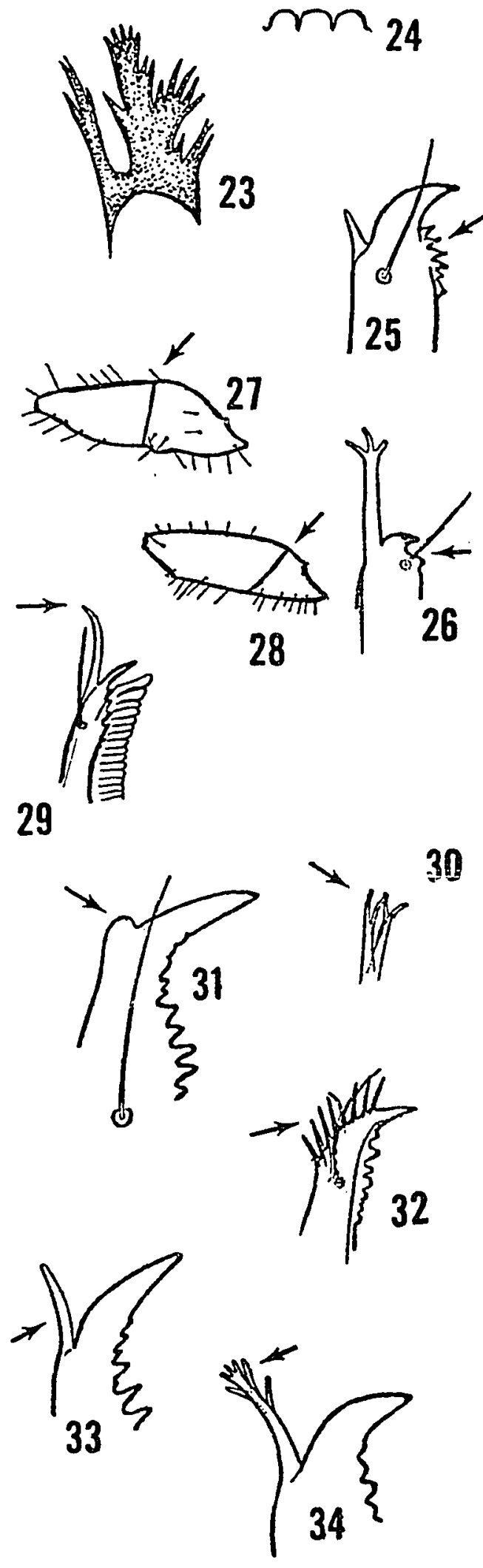

15. Palpal femur length greater than $0.43 \mathrm{~mm}$, chela length greater than $0.67 \mathrm{mon}$, one palr of moderately to well-developed eyes, coxal splne essentlally a wlde, single blade with deep inclsions (Fig. 23) ....................... M. paclficus, p. 32

Not as above............................. 16

16. Palpal fexur length less than $0.34 \mathrm{~mm}$, chela length less than $0.50 \mathrm{~mm}$ and chelal teeth markedly quadrate (FIg - 24)

........................ M. erosldens, p. 30

Not as above............ Mundochthonlus spp.. p. 29

17. Legs, each with 6 segments, exclusive of coxae (Appendix III) (suborder DIplosphyronida).... 18

Legs, each with 5 segments, exclusive of coxae (Fig, 3, 4) (suborder Monosphyronida)........ 26

18. Movable chellceral finger dentate $1 / 5$ or more of the length of Inner margin (FIg. 25) (superfanlly Neoblsloldea)................... 19

Movable chellceral finger with a single subaplcal tooth, sometimes secondarily subdlvided (F1g, 26) (supertamlly Garypoldea)

19. Abdomlnal pleural membrane granulate, nover smooth; suture separating the 2 femoral segments of leg IV perpendiculax to long axis of femur (Fig. 27) (family

Neoblsildae) ..............................

Abdominal pleural membrane smoothly and longltudinally plicate; femoral suture of leg IV slightly oblique to long aris of fewur (FIg. 28) (famlly Syarisidae) ........................ Syarlnus 8pp., P. 41

20. Mnvable chollceral Elnger with welladevoloped splnnerts, in the form of 1 or more galeate processes (F1gs, 29, 30) (subfamlly Ideoblalinao) ............................ 21

Yovable chellceral Ilnger without a galea, may have low sclerotle knob or tubercla (F18. 31) (sublamliy Nooblsilnae)

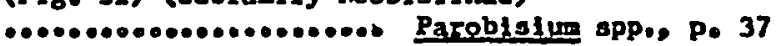

21. Splnnerat of movable chellceral finger comprisod of 8-10 simple galeae (F1g. 32) ................ Haloblslum occldentale, p. 39

Spinneret of movable chellceral finger of 1 Blmple or weakly brancted galea (Figs. $33,34) \ldots \ldots \ldots \ldots \ldots . . . .41$ crocreagris spp., p. 37 

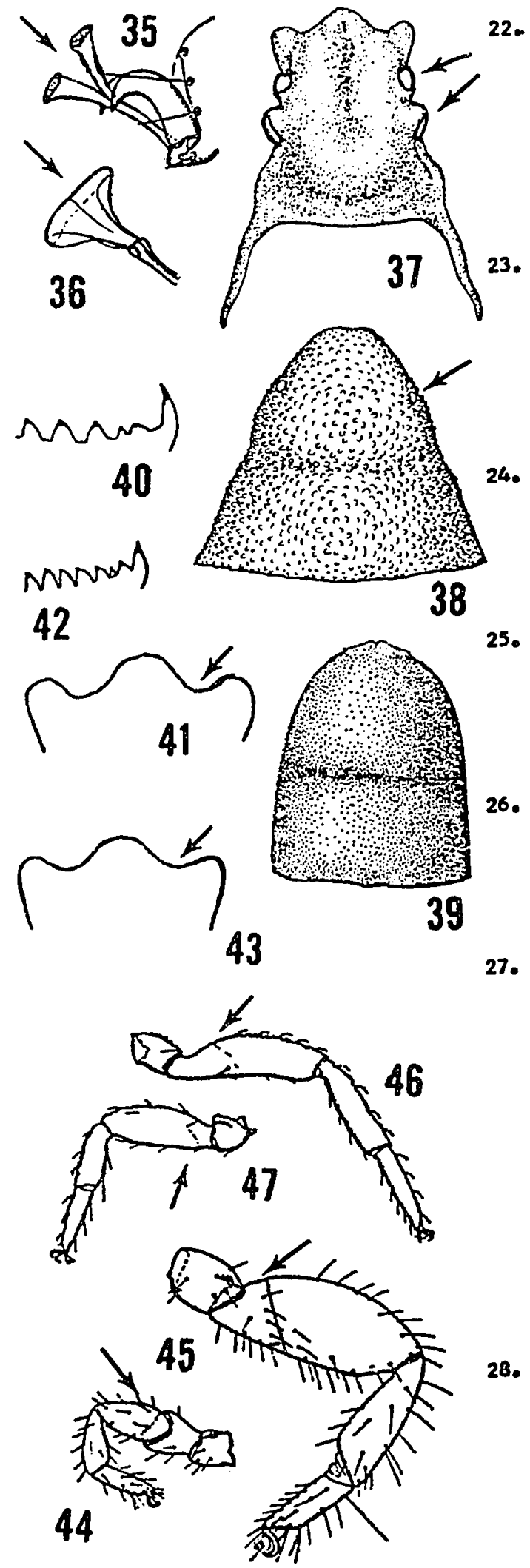

22. Pleural membrane smoothly and evenly pllcate; palpal setae slender and consplcuous (fanlly Olplldae)........................... 23

Pleural membrane not swoothly plicate but wrinkled or granulate; palpal setao usually short and Inconsplcuous (fanlly Carypldae)................................. 2

23. Tarsal arolla bifurcate (Flg. 35) \& palpal ferrir length of male $0.74 \mathrm{~m} 0.90 \mathrm{~mm}$, of female 0.75-0.97 ... Pseudogaryolnus frontal 1s, P. 51

Tarsal arolla entire (F1g. 36); palpal femur length of male 0.33-0.35 mom, of female 0.330.39

24. Chelal movable finger with 4 tactile setao .................... Archeolarca rotunda, p. 43

Chelal movable finger with less than 4 tactllo setae (genus Larca)........................ 25

25. Chelal einger with 3 tactile setae

......................... L. notha, p. 47

Chelal finger with 2 tact 110 sotao .................... L. chamber1lnl, p. 46

26. Four prodinent eyes (Flg. 37) (superfanily Feaelloldea, family Pseudogarypldae, genus Pseudogarypus) ....................... 27

Two eyes or none $(F+8,38,39) \ldots \ldots \ldots \ldots \ldots \ldots \ldots . . \ldots$

27. Chelal fixed finger with widely-spaced teeth (FIg. 40) i anterlor margin of carapace with deep notch between antero-lateral and median protuberances (Figo 41) i chelal length (Including podicol) 1.27-1.51 m, of feralo 1.31-1.61

Cholal elxed finger with teoth in distal half appoaring cont iguous in malo and only very slightly spaced in tomalo (Fig. 42), anter:= lor margin of carapaco with ahallow notch between antero-lateral and medlan protuborances (FIg. 43); chelal lengeh (Including pedlcel) of male 1.07-1.11 mon, of female 1.09-1.24 E.n.............. P. hesperua, P. 57

28. Fasora of legs I and II different in struce ture from fenora of legs III and IV (Flge. 46, 45) (superfanliy Challereroldea) ......... 33

Femora of all legs similar (Flgs, 46, 47) (supertanliy Choliddioldea, famlly Cheirldildae, genus Apachelridiua) 


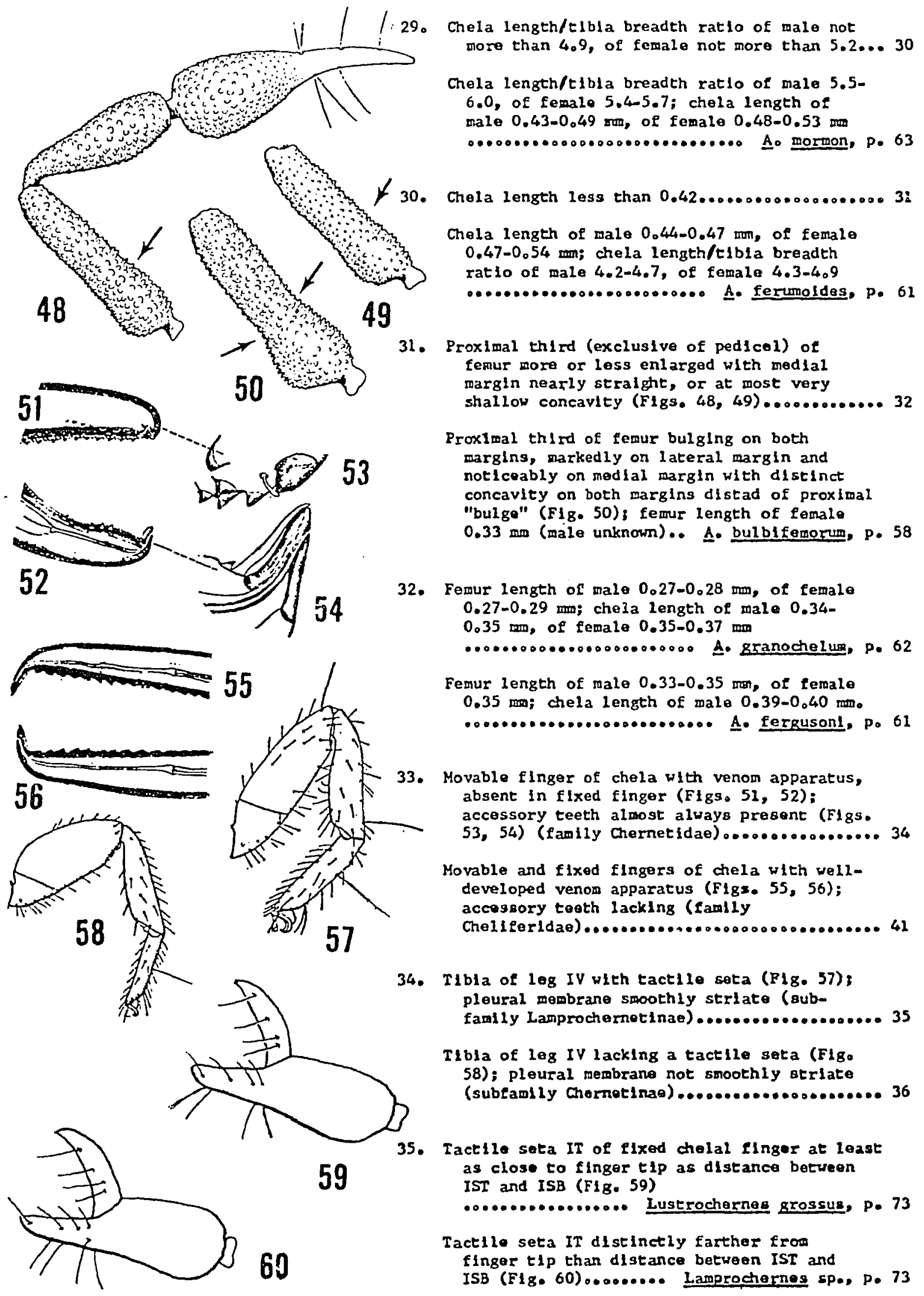




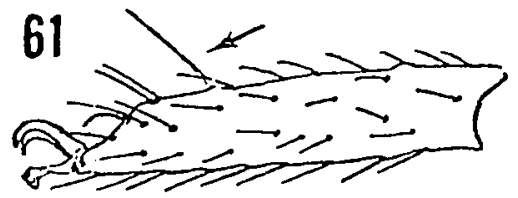

36. Tarsus of leg IV with a tactile seta

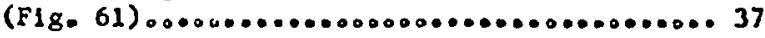

Tarsus of leg IV without a tactlle seta

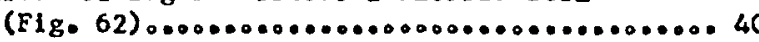

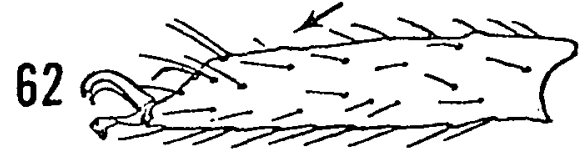

37. Movable chelal finger with tact lle seta ST closer to SB than to T (F1B. 63)

.........०००.. Dendrochernes crassus, p. 67
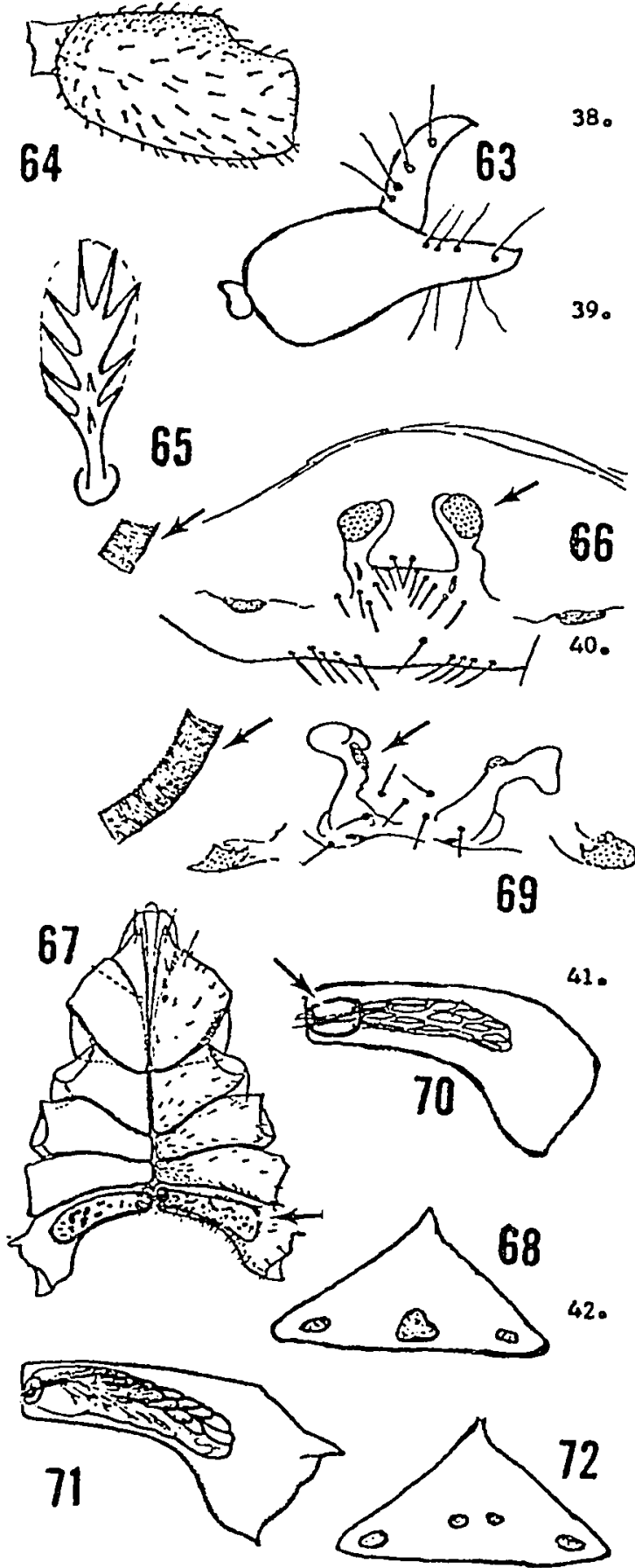

Movable chelal finger with tactile seta ST midnay or closer to T than to SB............. 38

38. Cheliceral hand with seta sb and b acuminateo.. Acuminochernes crassopalpus, p. 65

Cheliceral hand with sb dentlculate and $\underline{b}$ acuminate (genus Dlnochel rus) . 39

Palpal feinur of male with large protuberance on subdorsal (inner) surface (Fig* 64); tactile seta of tarsus IV greater than $70 \%$ of the total tarsal length from proximal margin.0.0............००o D. Stcarlus, P. 68

Palpal femur of male without a large protuberance on subdorsal surface; tactl le seta of tarsus IV less than $65 \%$ of the total tarsal length from proximal marglnoo Do validus, p. 69

Setae of palpo and tergltes bllaterally feathered and leafllke (F1g. 65); several extra long clavate setae near center of outer margin of fixed finger ............... Illinichermes Btephensl, P. 72

Setae of palps not bilaterally feathered; without extra long clavate setae near center of outer margin of flxed finger .............. Hesperochernes utahens1s, p. 70

Coxal sacs absent in male; cribriform plates of female palred and as largo in dlameter as the diameter of the anterlor tracheal trunks (F1g. 66).. Haplochel1fer ph111pl, P. 80

Coxal sacs present in male (Fig. 67); female with pedian cribrlform plate single (Fig. 68), or palred with dlameter much smaller than diameter of anterlor tracheal trunks

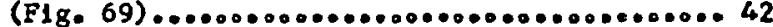

Coxal sacs of male with a woll-defined atrium (Fig. 70); fewale with a single medlan cribrlform plate .......... Dactylochallfor Bllvestris, $p_{\text {. }}$

Coxal sacs of male without an atrium (Fig. 71); female with palred median crlbrlfore plates (F1g. 72); tribe Chellferint (the following couplets ara based on male: inly) $\ldots \ldots \ldots \ldots \ldots 43$ 

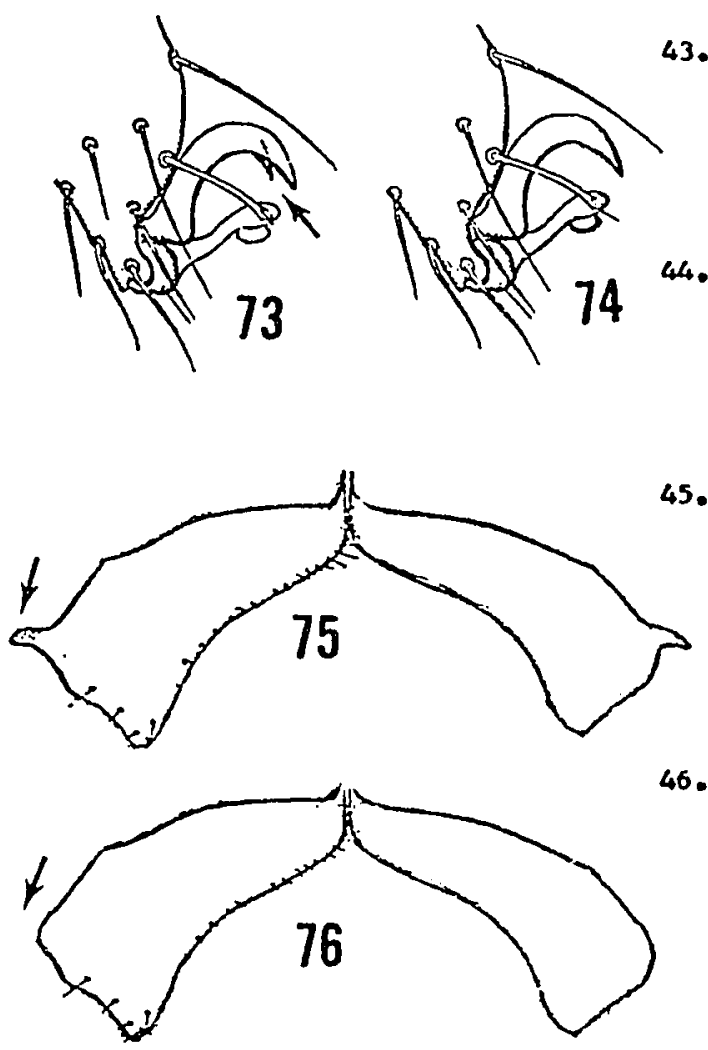

46. Male with a vell-developed antero-lateral

45.

Chela (exclusive of podlcel) less than $1.65 \mathrm{~mm}$ in length; movable finger shorter than hand ..................... E. scabrlculus, P. 86

Chela (exclusive of pedlcel) 1.7 mor or more in length; movable einger longer than hand ...................... P. persinil1s, p. 85 process (spur) on margin of coxa IV (FIg. 75); well-developed spurs present on at least tergites I to III (genus Hysterochel1fer) ............................

Male without an antero-lateral process ( $F I_{g}$. 76); spurs absent on tergltes, although lateral margin of terglte may appear very heavily-sclerotlzed and darkly plgwented ............ Aspurochellfer littlefleldl, p. 76

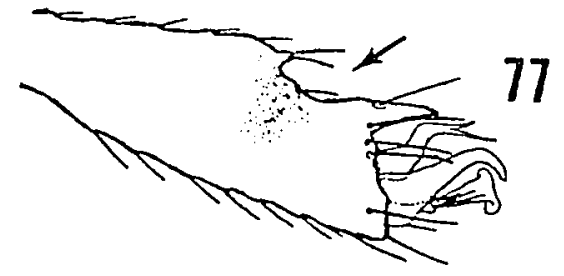

47. Tarsus of leg I with 2-3 very enlarged setlferous tubercles at proximal end of a deep sinus (Fig. 77); chela length (exclusive of pedicel, 1.10-1.50 ntw; femur length 0.75-1.07 chelal hand in lateral vlew slender, length/breadth rat lo 4.0-4.7 ........................ H. proprlus, P. 83

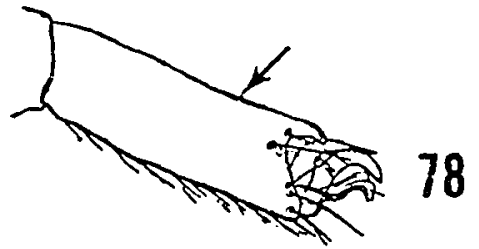

Tarsus of leg I without enlarged set ferous tubercles, alnus shallow (Fig. 78); chela length (exclusive of pedicel) $0.95-1.15 \mathrm{~mm}$; femur length $0.65-0.76 \mathrm{mon}$; chelal hand in lateral view stout, length/breadth ratlo $2.6-3.4 \ldots \ldots \ldots \ldots \ldots \ldots \ldots \ldots$ H. Eusclpes, p. 81 